\title{
Willingness to Pay Surveys for Setting Prices for Reproductive Health Products and Services: A User's Manual
}

Karen G. Fleischman Foreit

James R. Foreit

Population Council

Follow this and additional works at: https://knowledgecommons.popcouncil.org/departments_sbsr-rh

Part of the Family, Life Course, and Society Commons, International Public Health Commons, and the Maternal and Child Health Commons

How does access to this work benefit you? Let us know!

\section{Recommended Citation}

Foreit, Karen G. Fleischman and James R. Foreit. 2004. "Willingness to pay surveys for setting prices for reproductive health products and services: A user's manual," FRONTIERS Report. Washington, DC:

Population Council. 


\section{WILLINGNESS TO PAY SURVEYS FOR SETTING PRICES \\ FOR REPRODUCTIVE HEALTH PRODUCTS AND SERVICES}

\section{A User's Manual}

Karen G. Fleischman Foreit

POLICY Project

The Futures Group International
James R. Foreit

FRONTIERS

The Population Council

This publication was made possible through support provided by the U.S. AGENCY FOR INTERNATIONAL DEVELOPMENT (USAID) under the terms of Cooperative Agreement Number HRN-A-00-98-0012-00, the Population Council's Frontiers in Reproductive Health Program (FRONTIERS), and Contract Number HRN-C-00-00-00006-00, The Futures Group International's POLICY Project.

Revised 2004.

(C) 2004 by the Population Council. All rights reserved. 


\section{TABLE OF CONTENTS}

Acknowledgments....................................................................

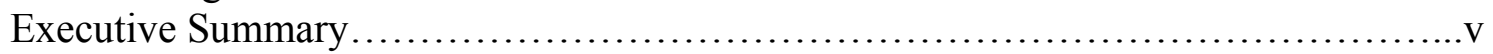

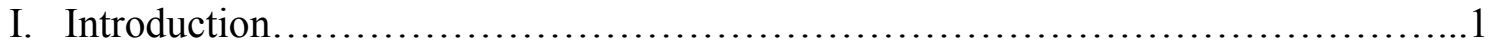

II. Willingness To Pay Surveys: What Are They?................................

III. Willingness To Pay Surveys: How To Do Them .............................. 3

Preliminary Steps.................................................. 3

Questionnaire Design.................................................4

Data Analysis.........................................................

Estimating Demand At Different Price Levels ............................10

IV. Applications ............................................................. 12

Mali: Raising Prices For Existing Products...............................14

Pakistan: Setting Prices For New Products................................19

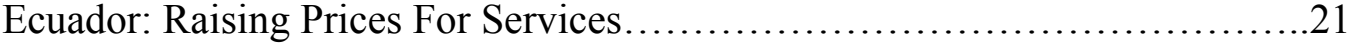

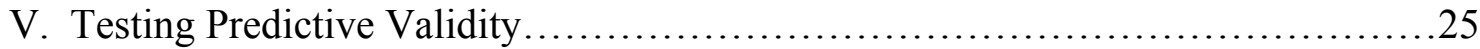

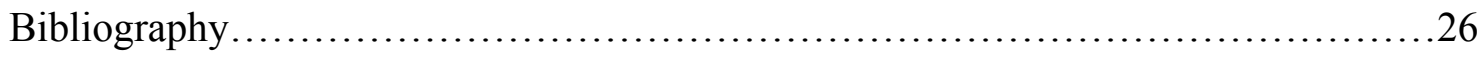

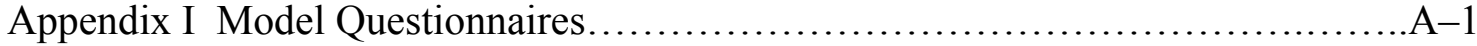

Appendix II Model Interviewers' Manual And Model Coding Manual.............A-20 


\section{Acknowledgments}

The authors wish to acknowledge the work of our collaborators. Dan Kress of Abt Associates first brought the willingness to pay (WTP) technique to our attention and directed WTP surveys in Ghana and Pakistan. John Bratt of Family Health International played a leading role in WTP studies in Ecuador and Guatemala. Varuni Dayaratna of The Futures Group International, Caroline Blair of the Population Reference Bureau, Carlos Brambila of the Population Council, and Barbara Janowitz of Family Health International were co-workers on WTP studies in Ecuador, Guatemala, Mali, and the Philippines, respectively. Special thanks go to William Winfrey, also of The Futures Group International, for advice during several surveys and drafts of this document. Funding under different contracts and grants from the U.S. Agency for International Development (USAID) Office of Population, Health, and Nutrition, USAID/Accra, and USAID/Bamako supported the surveys described in this document, except for Pakistan, which was supported by a DfID contract to The Futures Group International. This manual was developed under the Population Council's Frontiers in Reproductive Health Program (FRONTIERS) and The Futures Group International's POLICY Project, both of which are supported by USAID. 


\section{Executive Summary}

Social programs need to balance volume (coverage) and revenue (sustainability). The law of demand says that we cannot get both coverage and sustainability at the same time - as prices go up, demand will come down. Client loss with increasing prices is inevitable, except in those cases where starting prices are so low or demand is so high that demand is insensitive to price changes. Willingness to pay (WTP) surveys allow program managers to simulate price-related changes in demand without actually changing prices, giving them a way to make pricing decisions based on empirical information. Benefits of WTP surveys are as follows:

- The survey methodology is simple and unobtrusive to apply, and the direct estimation techniques can be applied by any research unit.

- WTP techniques can be used for both existing products and services and new goods that are not yet available in the market. Depending on the program context and decisions to be made, the survey can be administered to either population-based or facility-based samples.

- Even clients without formal education can answer hypothetical price questions, and their answers are usually internally consistent.

- WTP estimates are sensitive to client characteristics, such as motivation to use the product or service, or socioeconomic status (SES).

- Direct WTP estimates are conservative; that is, they underestimate maximum WTP and protect program managers from raising prices too high.

- Information provided by WTP surveys improves the accuracy of predicting responses to price change. While the estimates do not provide perfect predictions, errors do not seem to be systematically related to characteristics of the program such as initial price or volume.

This said, however, two cautionary notes are in order:

1. The hypothetical price range to be tested should be determined prior to applying the full-scale WTP survey, in consultation with program management. Target prices should be based on programmatically relevant information, such as program costs to deliver the service or product, program needs for additional revenue to meet rising costs or to cross-subsidize other activities, prices at competing outlets, and so forth.

2. Further study is needed to validate the results of decisionmaking based on WTP surveys. At the very least, program managers should monitor demand before, during, and after price changes. Additional field experiments are needed to assess the accuracy and sensitivity of WTP-derived estimates of changes in use. 


\section{Introduction}

In making pricing decisions, managers of social programs face an equity dilemma - the problem of balancing the need for program sustainability with the social goal of making services available to low income clients. Raising prices too high will deny services to poor clients. However, maintaining needlessly low prices will perpetuate reliance on external donors. Until recently, managers have been forced to make pricing decisions without a reliable methodology for predicting the effect of price changes on program revenues or use. This paper describes a simple survey technique to estimate client willingness to pay (WTP) for goods and services, thus allowing managers to make rational pricing decisions.

Setting prices is a key decision for any program that provides goods or services. Where commercial managers strive to maximize profits, increase market share, or discourage competition, managers of public and nonprofit organizations focus on affordability, sustainability, and coverage. The challenge for social programs is to set prices low enough to be affordable to the target clientele and yet high enough to avoid cannibalizing self-supporting, fully commercial brands and services. The potential range of prices may be quite broad, and there is usually no optimal price for a program to charge.

The "law of demand" states that demand is inversely related to price. As prices increase, sales or use declines, and as prices decline, sales increase. This relationship, however, may break down at the extremes. There may be a minimum price below which further reductions do not lead to more sales. ${ }^{1}$ Similarly, once prices are so high that no one buys anything, further increases cannot reduce sales. Therefore, we expect the relationship between price and sales to look like the "demand curve" presented in Figure 1. ${ }^{2}$

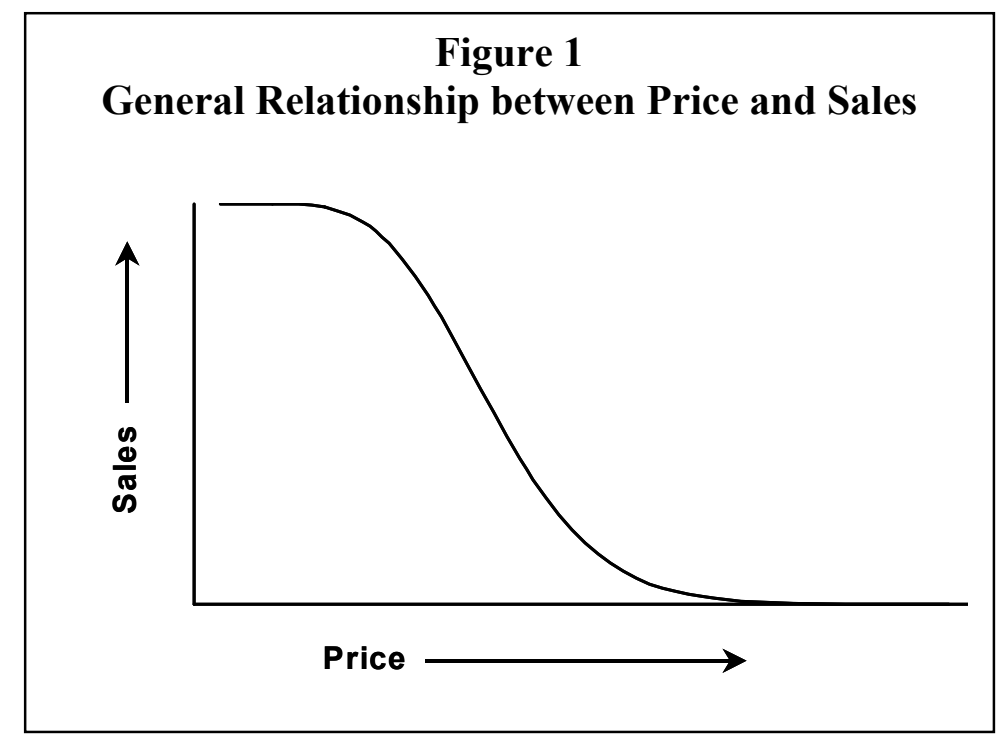

The shape of the demand curve for a particular product or service will depend on many factors, including alternative methods, brands, and sources of supply, as well as clients' income and motivation to use the product or service. If there are many competing alternatives in the market and clients' income is low, sales or use might drop quickly as prices increase. On the other hand, if there are few alternatives and clients' motivation to use is high, sales or use might be less affected by changes in price.

\footnotetext{
${ }^{1}$ Oliver (1994) found that reducing the price of spermicides to zero at Ministry of Health facilities in Ghana increased the probability of using a modern contraceptive method by only 5 percent, probably because prices were so low to begin with. Other researchers have reported similar results in Thailand (Akin and Schwartz 1988), Indonesia (Jensen et al. 1993), and Ecuador (Bratt et al. 1998; Leon and Cuesta 1993).

${ }^{2}$ Economists traditionally place price on the vertical (Y) axis. In this paper, we will place sales on the $\mathrm{Y}$ axis in keeping with the tradition of behavioral scientists to place the dependent variable on that axis. Sales is the dependent variable in the law of demand because the variable is considered to be determined or influenced by price.
} 


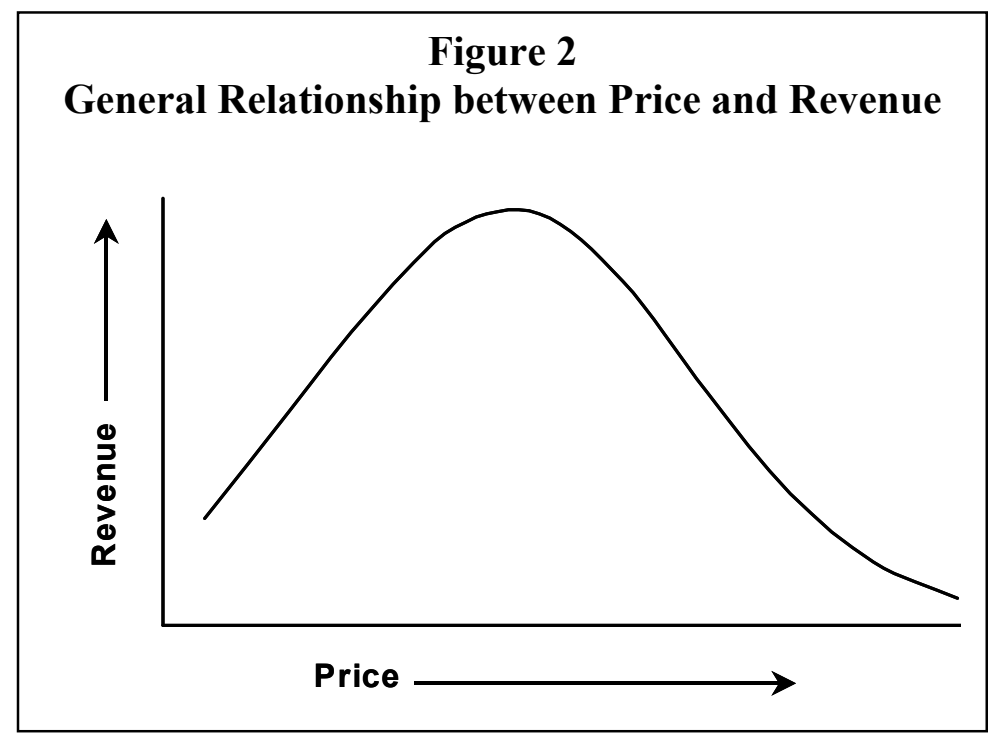

Expected revenues are calculated by multiplying expected number of sales by price per unit sale. Depending on the shape of the demand curve, within certain price ranges, declining sales will be more than compensated for by increased price, and price increases will lead to increased revenues. At other price ranges, small increases will lead to relatively large declines in sales and price increases will lead to decreased revenues.

Knowing the shape and height of the revenue curve allows managers to estimate the costs they will recover at different price levels (Figure 2). ${ }^{3}$ Many programs have both sustainability and access goals. Being able to predict client response to price levels would help managers estimate the impact of a proposed price increase on both revenues and use of product or service.

How can we know what consumers' purchase behavior will be at different prices? Empirically, we could raise prices and measure sales, continuing to raise prices until demand falls to unacceptable levels or revenues begin to decline and then retreat to a lower price. Obviously, most program managers would be reluctant to experiment with their client base and revenues this way. An alternative approach is to ask current or potential clients how much they would be willing to pay for their product or service. ${ }^{4}$

\section{Willingness to Pay Surveys: What Are They?}

WTP surveys measure potential demand for products or services by asking consumers, "Would you purchase this product if it were offered at this price?" They are frequently used in health, social, and environmental programs for price setting and cost-benefit analyses. When a few simple analyses are performed, WTP survey data permit program managers to estimate the number of clients who will pay a given price, the amount of revenue that will be generated by that price, and if the appropriate questions are included in the questionnaire, the characteristics of individuals who will or will not pay that price. When more complicated analyses are performed, the data can also be used to estimate the revenue maximizing price for a product or service. The basic WTP survey is quick to administer and requires relatively modest sample sizes.

\footnotetext{
${ }^{3}$ Revenue is only one part of the equation determining sustainability. Program costs may not show a one-to-one correspondence with sales, hence net profits (or losses) may not exactly mirror revenues.

${ }^{4}$ This approach to WTP is also called "contingent valuation."
} 


\section{Willingness to Pay Surveys: How to Do Them}

\section{Preliminary Steps}

WTP surveys help answer the question "How much can we charge?" Before trying to answer this question with a WTP survey, we must have the answer to another question "How much should we charge?" Prices to be tested in a WTP survey should be based on some programmatic objective. This objective must be clearly articulated before the willingness to pay survey is designed.

In addition, there are two basic questions to ask the program manager: "Whom do you wish to serve?" and "What do you plan to do with the revenue generated by charging or raising your prices?" These questions focus the investigation on the program's target population and on its financial objectives.

Know your target population. Most service providers try to reach specific kinds of clients. Social programs, such as ministries of health and nongovernmental organizations (NGOs), often define their target markets in terms of income, ability to pay, or lack of access to commercial outlets. Since different groups of clients may react differently to price increases, specifying the target population in advance allows the investigator to include these characteristics in the survey and focus the analysis on those individuals of greatest importance to the program.

Know your financial objectives. The most common motives for raising revenues are to keep pace with increasing costs or inflation, to increase cost recovery in order to decrease reliance on external donations (i.e., sustainability), or to generate surplus revenues in order to expand services or to subsidize other program activities. All require that program managers know what their real costs are, which is a study in discipline itself. If the objective of the new price is to purchase contraceptives, then the manager needs to know how much contraceptives cost. If the objective is to generate excess revenues to subsidize another service, then the costs of both services must be known. Finally, if the objective is to improve overall sustainability, then all program costs must be known. This includes both the commodities and supplies used during the consultation and/or provided to the client (including wholesale prices paid or the value of donations, packaging, transport, storage, etc.) and the ancillary costs associated with the service provision (salaries, rent and utilities, equipment, maintenance, etc.). There are various ways of classifying program costs, for example, fixed costs (such as salaries and rent, which remain the same no matter how many clients are seen or services provided) and variable costs (which are associated with the particular service provided, such as the commodities and supplies used).

Select a small number of products or services. Marketing programs are usually interested in WTP for only one or a small number of products. Clinical programs, however, are sometimes interested in setting or increasing prices for a large number of products or services. Although large numbers of services can be included in a WTP survey, it is usually best to focus on no more than three to four priority services. Low volume services that contribute little to costs or revenues should not be included because of the difficulty of obtaining a large enough sample for reliable decisionmaking.

Know your current prices. Prices actually charged in program outlets may not be the same as those established by the organization headquarters. Price data at the central level are often out-of-date or incomplete. Call or visit each clinic that is to be included in the study to obtain the true current prices for all services to be covered in the survey. In social or commercial marketing applications, a product will often be offered at different prices in different outlets. Reliable information on the current price range of the product should be obtained before beginning the survey. 
Know your current and past service volume. Accurate service statistics or sales records are essential to the appropriate interpretation of survey findings. Demand for many health products, such as oral rehydration salts or mosquito bed nets, may fluctuate with the season of the year, and clinic hours may be curtailed during public or religious holidays. Price increases may have different effects in new settings where client demand is growing than in established settings where demand has been constant or even declining.

Select sampling strategies. The type of sampling and sample size used in a WTP survey will depend on the nature of the product or service under study and the precision of the results required. The programmatic question should determine the study design. If a clinic manager wants to know the impact of a price increase on his/her current clientele, the appropriate place to conduct interviews is in the clinic itself. A price-setting survey for products that are intended to be sold through pharmacies can be conducted with customers leaving pharmacies (known as a pharmacy-intercept survey). The introduction of new services or products or WTP among individuals who are not currently using the service may best be studied with population-based samples representative of the country as a whole or specific geographic or socioeconomic status (SES) areas.

In general terms, precision of the estimate increases with larger sample sizes, and sample sizes and survey costs increase with the number of products and/or services and service delivery points included in the survey. Surveys in clinic settings have tended, for efficiency purposes, to conduct exit interviews with all clients obtaining services in a set of clinics during a fixed period (usually 2-4 weeks, depending on client volume). This is a viable option if the clinic has a large clientele; however, it may be prohibitively expensive to obtain a reliable number of observations in small service delivery points, such as community-based distributors or rural health posts, which may serve no more than one or two clients per day.

Select a stand-alone survey or module in a larger survey. Money can be saved by including the basic set of WTP questions in a survey conducted for another reason, such as a client satisfaction exit survey in a reproductive health clinic. However, collaboration opportunities are often limited by the sample characteristics and timeliness of the larger survey.

\section{Questionnaire Design}

The National Oceanic and Atmospheric Administration has established best practice rules in order to overcome the major sources of bias associated with WTP surveys. ${ }^{5}$ They recommend that WTP surveys should (1) rely on personal interviews; (2) use close-ended questions that elicit the respondents' WTP to a specified increment for a service that is familiar to them; (3) remind respondents that the price increment reduces other consumption; (4) remind respondents that substitutes exist for the service in question; and (5) question respondents about factors that might influence their preferences.

Most research organizations require that the interviewee give informed consent before proceeding with an interview. Informed consent is a communication process between the researcher and the potential participant; it is also a legal requirement in the US. The study participant must be fully informed about the purpose of the study, understands the information, and is empowered to make a voluntary decision about whether or not to participate in the study. Informed consent derives from medical research where there are risks and benefits. Essential elements of informed consent include:

\footnotetext{
${ }^{5}$ In the aftermath of the Exxon Valdez oil spill, the U.S. Department of Commerce convened a panel of experts to determine whether estimates of loss derived through the WTP method were sufficiently reliable for use in a natural resource damage assessment. See Portnoy (1994) and Phillips et al. (1997). The guidelines described here seek to minimize response biases introduced if respondents do not understand the questions, if they cannot answer the questions, if they do not answer truthfully or give answers to please the interviewer, or if they answer "strategically" to influence the study outcome in their favor.
} 
1. Purpose of study.

2. Risks to the study participant, including physical, social, and emotional.

3. Benefits to the study participant, including, if necessary, a statement that there are none.

4. Information on confidentiality, including the use of identifiers and access to personal data.

5. Place to go with questions or problems at any time.

6. Information regarding withdrawal from the study. The study participant has the right to leave at any time without penalty.

7. Guarantee that services are available whether or not the potential respondent agrees to participate in the study, or if s/he withdraws.

8. Information on study procedures and duration.

Consent forms should use simple sentences and direct statements, appropriate to the literacy or educational level of the setting. The study participant must have an opportunity to ask questions and be fully informed before signing the consent form. One example of an informed consent statement is given in Appendix I.

In practice, respondents need to understand the context of the questions; that is, they need to understand exactly what it is they would be purchasing. This is less of a problem when current users are asked their willingness to continue purchasing a product or service at a higher price, or if nonusers are asked about a product or service they have used in the past. It may, however, be difficult to ask respondents about something they have never used, such as a new product. When examining WTP for new products, it is best to show a product sample to the respondent and provide a full description of the product. Also, when dealing with a nonuser, first ascertain her/his interest in using the product.

In addition, the way questions about prices are asked may influence the answers given. Asking respondents a single, direct, open-ended question- "What is the most you would pay for this product?"does not produce reliable answers. Instead, researchers agree that it is better to pose explicit price questions and ask respondents to answer yes or no (or don't know). The survey should include enough questions to cover the price range of interest without unduly fatiguing the respondent. Also, the order of questions should be chosen so as not to bias the respondent into naming a higher or lower maximum price than she really means.

Questioning should begin by asking respondents what they currently pay for their method or service. Respondents should then be asked whether they would continue to purchase the product or service if its price increased by a set amount. Respondents who answer that they would still purchase the product or service are asked if they would pay an even higher price. Respondents who answer that they would not or are unsure are asked if they would pay a lower price, which is still higher than their current price. Note that all respondents are asked exactly three price questions: their current price $[\mathrm{P}(0)]$, a medium price increase $[\mathrm{P}(2)]$, and, depending on their answer to the medium price increase, either a low price increase $[\mathrm{P}(1)]$ or a high price increase $[\mathrm{P}(3)]$. No single respondent is asked about all four prices, and the actual prices asked will differ among respondents according to differences in the prices they are currently paying.

Figure 3 illustrates the order of questions applied to respondents who are currently using the product or service. Respondents who are not current users should first be asked about their interest in using the service; the WTP questions begin with Question 2 in Figure 3 and are phrased as absolute prices rather than price increases.

When developing the questionnaire, the researcher should put the target price in either the question concerning the low price increment or medium price increment, but not the highest increment. Experience suggests that users and prospective users in developing countries often treat the WTP questions as a 


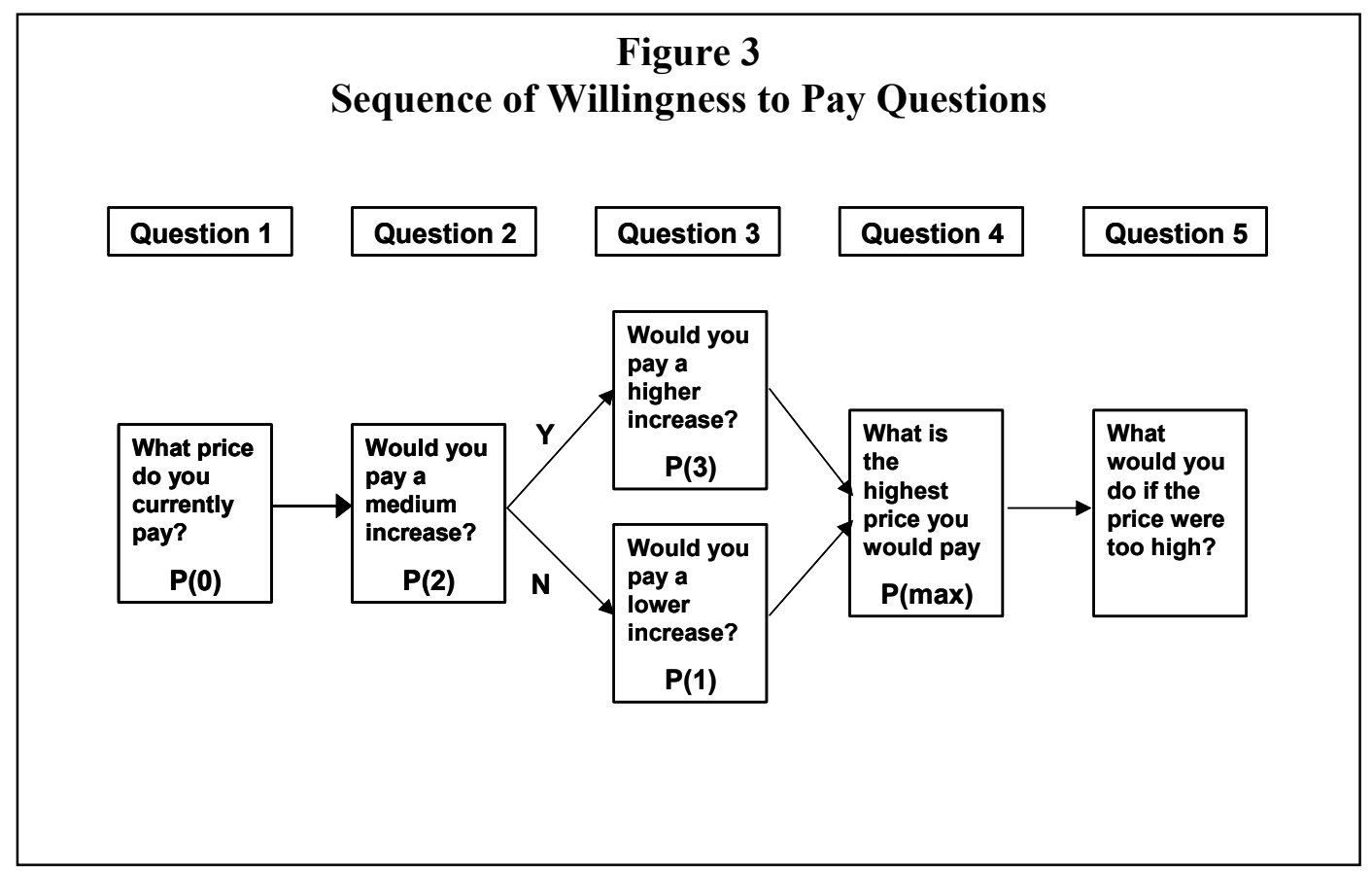

bargaining situation. They are more willing to pay a given price when it is the low price increment than when it is the medium price increment (first price asked) or the highest price increment.

Two additional price-related questions are highly recommended. The first is to ask all respondents to name, regardless of their answer to Question 3, the maximum price they would be willing to pay. For respondents who answer yes to the highest price asked, this extends the price range under question. For respondents who answer no to the final price asked, this permits a finer distinction between the highest price agreed to and the lowest unacceptable price. Data from the maximum price question can also be used to check the internal consistency of responses (the number of respondents stating a maximum WTP that is lower than their current price paid, or the price increment accepted in the closed-ended questions should, ideally, be trivial). Lastly, respondents can be asked what they would do if prices were increased beyond the limit they would be willing to pay. This question may help a private program establish its market niche, or a public program manager seeking to estimate the need for a social safety net.

Questions concerning client characteristics should always be included in WTP surveys. These questions identify the characteristics of clients who will or will not pay a given price, and are often used to establish the respondent's wealth, discretionary income, or ability to pay. The most commonly used wealth indicators include education, family income, possession of durable goods, recent expenditures on other health care services and products, and expenditures on nonessential items, such as beauty parlors. The specific questions that need to be included depend on the country where the study is being conducted. Demographic and Health Surveys (DHS) are a good source of questions on education and durable goods. Examples are also provided in the model questionnaire for clinic services (see Appendix I). Education, income, and possession of durable goods are all highly correlated; thus, the researcher may wish to use only one question (such as the education variable) where the interview must be conducted in a very short time or where income questions are highly sensitive.

Additional questions that probe interest in or motivation to use a product or service must be added to the WTP questionnaire when interviewing potential users. WTP information obtained from respondents who have no intention of purchasing the product or service in question is unlikely to be useful. Respondents may be asked to rate their interest (e.g., "Would you say that you are very interested in being sterilized 
within the next two years, somewhat interested, or not at all interested?") or answer yes or no to a question asking if they are interested in using a contraceptive method or other reproductive health service. The researcher will probably want to exclude from the WTP analysis persons with low motivation.

The WTP technique described above assumes that only the price varies and all other factors remain equal. Researchers and managers may also want to know if clients would be willing to pay more if some aspects of the service are improved, such as reducing waiting time or installing more comfortable seats, and which factors would elicit a greater WTP. The preferred research technique in this situation is conjoint analysis, in which respondents are asked to choose between pairs of combinations of prices and service attributes. For example, "Would you prefer to pay $\$ 5$ for your IUD revisit, sit on hard plastic chairs, and wait one hour, or pay $\$ 15$ and sit on an upholstered chair and wait only 10 minutes?" The number of questions asked depends on the number of prices and service attributes probed; assessing two prices and two attributes would require a minimum of eight questions.

\section{Data Analysis}

\section{Direct estimation method for calculating the demand curve}

Current and potential users are analyzed the same way. To calculate the demand curve, we make the following assumptions:

- Clients are willing to pay the price they are currently paying for their product or service.

- An individual's maximum price is the highest price she has explicitly agreed to. If a respondent answers no to $\$ 4$ and yes to $\$ 2$, the maximum price would be $\$ 2$.

- Willingness to pay is transitive downwards: clients who are willing to pay a given price for a product or service are also willing to pay any lower price for that product or service.

- Unwillingness to pay is transitive upwards: clients who are not willing to pay a given price for a product or service are also unwilling to pay any higher price.

Once these assumptions are considered, the steps below should be followed:

1. Establish each respondent's maximum price willing to pay. ${ }^{6}$ If respondents are asked about price increases, the maximum price willing to pay is computed by adding the maximum price increase to the current price paid. If respondents are asked about absolute prices, the maximum price willing to pay is the maximum price stated.

2. Eliminate nonresponses and internally inconsistent respondents (yea-saying). Respondents who answer don 't know to all questions should be eliminated from analysis. However, a respondent who answers don't know to the standardized price probes but gives his/her maximum price willing to pay should be included, as should respondents who give yes or no answers to the price probes but are unable to state their maximum price willing to pay. In the latter case, the maximum price would be estimated as the highest price probe accepted or the current price if no price probe is accepted.

\footnotetext{
${ }^{6}$ This section assumes that all interviews end with the open-ended question, "What is the highest price [increase] you would pay?" (Question 4 in Figure 3). If the open-ended question is not asked of all respondents, the analysis is more complicated and requires removing some respondents from analysis at higher price levels.
} 
All responses with a maximum WTP price should be examined for internal consistency. The maximum price stated should be equal to or higher than the highest price probe accepted.

Respondents who state a maximum price lower than the highest price probe accepted or the current price paid should be eliminated from the analysis.

Keep track of the proportion of respondents eliminated for nonresponse or internal inconsistency. If this proportion is so large as to substantially alter the findings, the survey itself is of questionable utility, and the reasons for respondents' difficulty with the questionnaire should be investigated.

3. Run a frequency distribution of maximum price willing to pay. 
4. Establish the price increments that will be presented along the $x$-axis of the demand curve as shown in Figure 1. Plot percentage demand at each price increment using the complement of the cumulative frequency from the frequency distribution and the transitivity decision rules described above. The percentage of respondents who will accept price $x$ is calculated (100 minus the percentage whose maximum price is lower than $x$ ). Table 1 illustrates the calculation.

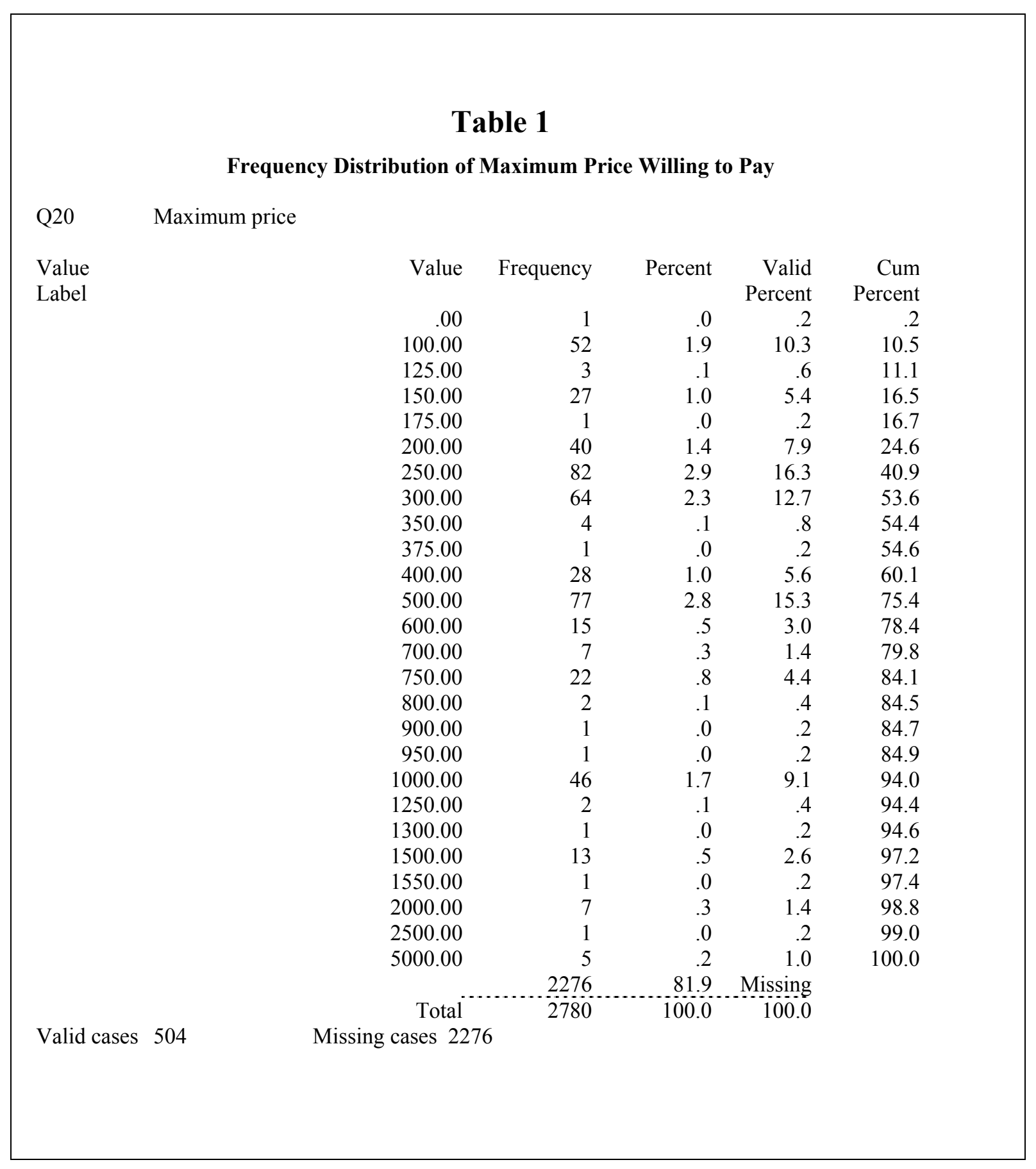


Suppose we want to plot the demand curve in 50-franc price increments, starting at 50 francs. One respondent ( 0.2 cumulative percentage) gave a maximum price of 0 ; therefore, the percentage of respondents willing to pay 50 francs is $100-0.2=99.8$ percent. Since no one gave a maximum price between 0 and 100 francs, the percentage willing to pay of 100 francs is 99.8 . Fifty-two respondents declared 100 francs and three respondents declared 125 francs as their maximum price; therefore, the percentage willing to pay 150 francs is $100-11.1=88.9$. The percentage willing to pay 200 francs is the complement of the cumulative percentage giving a lower price (175 francs): $100-16.7=83.3$, and so on.

In a similar manner, respondents may be disaggregated by socioeconcomic status (SES) and the resulting demand curves compared to determine the impact of different prices on client or potential client profiles.

The direct analysis procedure outlined above will tend to underestimate maximum WTP because only a few price probes are asked, and many respondents may simply repeat the highest probe accepted as the maximum price they are willing to pay. Health economists who conduct cost-benefit analysis often need finer estimates of maximum WTP. ${ }^{7}$ For this reason, they tend to use multiple regression modeling techniques instead of direct estimation. However, most social programs are interested in neither revenue maximization nor cost-benefit analysis. If the program manager has already determined the target price and included it as the low price probe, these procedures will provide conservative estimates of WTP prices in the target range.

Often, a program will have different prices for the same service at different locations. Depending on the manager's needs, respondents can be aggregated across all service sites to calculate a single demand curve (first calculating maximum price willing to pay by adding the highest price increment accepted or stated to the current price), or separate demand curves can be calculated for each site or group of sites with a common price.

\section{Estimating Demand at Different Price Levels}

The WTP analysis described above establishes relative demand at different prices (i.e., the percentage of respondents who would pay each price for the good or service). Estimating absolute demand - how many clients the program would have at a given price-requires an additional, independent data source. For existing sales or clientele, that data source would be current volume (corrected for seasonal variations and/or recent trends).

Following the "law of demand," we assume that client volume will decline if prices increase. We can estimate new client volume at higher prices by combining the aggregate demand curve and service statistics as follows:

1. Estimate aggregate demand for the current and proposed new price. If all respondents are currently paying the same price, the demand at the current price is 100 percent. However, if different sites charge different prices, the aggregate demand at the current price of a high-priced facility will be less than 100 percent.

2. Compute the ratio of aggregate demand at the new price divided by aggregate demand at the current price. The complement of the resulting demand ratio (100-ratio) is the predicted percentage decline that could be expected if prices were raised to the new level.

\footnotetext{
${ }^{7}$ WTP is often used in health economics to assign a monetary value to the health benefit that a client receives from a good or service. This monetary value may be defined as the maximum price the client would be willing to pay.
} 
3. Multiply the demand ratio by current service volume. The product of the demand ratio times current service volume is the predicted service volume that could be expected if prices were raised to the new level.

4. Multiply current price by current service volume. If all clients pay this price, this is the revenue currently generated. Multiply predicted service volume by the proposed new price; if all clients pay the new price, this would be the predicted revenue generated at the new price level.

While one can predict how many or what proportion of clients we would lose if prices were raised, the reverse is not necessarily true - one cannot predict from a facility-based sample survey how many clients we would gain if current prices were lowered. To tap potential additional demand one would need an estimate of how many people are currently not using our service solely because of our current price, and how much these nonusers would be willing to pay. A population-based survey might be able to provide this information, but it should be noted that surveys such as the DHS consistently find that price is a minor reason cited for not using a method.

For new products or services, one would need an independent measure of our potential market. Failure to purchase a new product at its established price will include both those unwilling to pay that price as well as those who would not use the product at any price, even if it were given away free of charge. A proxy for market size might be the proportion of respondents who seem highly motivated to use the product or service; relative demand at different prices could be compared for this subset of respondents, as above, and extrapolated to the population at large.

\section{Monitoring survey progress}

All projects need to be planned and monitored, and WTP surveys are no exception. The checklist below can help the researcher to plan and monitor the survey. The first section lists policy issues that program decisionmakers must resolve before the survey can be designed. Each question in the first column requires an answer in the next column. For example, the first Policy Issue asks the program decisionmaker why prices should be implemented or raised. If the Policy Decision is "Cost recovery", the next Policy Issue, requires them to explain what costs will be recovered.

The second section, Survey Design, lists the elements that must be selected before survey launch, such as what clinics will be included. Specific facilities will be listed in Survey Design Decision. The third section, Survey Implementation, lists the tasks to be completed during the survey, including interviewing clients and cleaning and entering the data. The second column indicates the individuals or organizations responsible for the tasks. The final column is used for task completion dates. 
Table 2

WTP Survey Decision and Task Responsibility Checklist

\begin{tabular}{|l|l|l|}
\hline I. Policy Issues & Policy Decision (illustrative) & Completion Date \\
\hline Why charge for services? & $\begin{array}{l}\text { Cost recovery } \\
\text { Increase revenue } \\
\text { Other }\end{array}$ & \\
\hline $\begin{array}{l}\text { If cost recovery, recovery } \\
\text { of what costs? }\end{array}$ & $\begin{array}{l}\text { Variable costs? } \\
\text { Commodities? }\end{array}$ & \\
\hline Which services & & \\
\hline At which facilities & & \\
\hline & & \\
\hline II. Survey Design & Survey Design Decision & \\
\hline Geographic coverage & & \\
\hline Facility coverage (types) & & \\
\hline $\begin{array}{l}\text { Unit of } \\
\text { analysis/breakdown }\end{array}$ & & \\
\hline Sample size per cell & & \\
\hline Daily client flow & & \\
\hline Budget & & \\
\hline & & \\
\hline III. Survey & Responsibility & \\
\hline Implementation & & \\
\hline Questionnaire design & & \\
\hline Sampling frame & & \\
\hline Field work & & \\
\hline Data entry/cleaning & & \\
\hline Data analysis & & \\
\hline Report preparation & & \\
\hline Dissemination & & \\
\hline & & \\
\hline Soun: Bad & & \\
\hline
\end{tabular}

Source: Based on checklist developed by The Futures Group International for use in WTP survey planning. 


\section{Applications}

In the last few years, the WTP technique has been extensively used by Family Health International's Health Services Research Group, The Futures Group International, and the Population Council's FRONTIERS Program to help managers in developing countries make pricing decisions for reproductive health products and services. Other groups using similar methodological approaches include International Planned Parenthood Federation (IPPF) Western Hemisphere Region, and the Commercial Market Strategies Project (CMS). Information on these surveys and their application is shown in Table 3. The remainder of this section presents three case studies of the WTP methodology, which includes findings on the reliability and validity of the technique.

Table 3

\section{Recent Reproductive Health Willingness to Pay Surveys}

\begin{tabular}{|c|c|c|c|}
\hline Country/Agency/Year & Sample & $\begin{array}{l}\text { Products/ } \\
\text { Services }\end{array}$ & $\mathbf{T A} *$ \\
\hline $\begin{array}{l}\text { Ghana: GSMF 1995, Contraceptive } \\
\text { social marketing of new and } \\
\text { existing products }\end{array}$ & $\begin{array}{l}\text { National representative } \\
\text { sample of } 3,016 \text { women }\end{array}$ & $\begin{array}{l}\text { Supply Contraceptives } \\
\text { Female Condom }\end{array}$ & TFGI \\
\hline $\begin{array}{l}\text { Pakistan: PPSPP Project, } 1996, \\
\text { Contraceptive social marketing of } \\
\text { new products }\end{array}$ & $\begin{array}{l}\text { Representative sample of } \\
1,753 \text { married urban and } \\
\text { peri-urban women }\end{array}$ & Supply Contraceptives & TFGI \\
\hline $\begin{array}{l}\text { Ecuador: CEMOPLAF, } 1997, \\
\text { NGO clinic services }\end{array}$ & $\begin{array}{l}\text { Systematic sample of } 3,661 \\
\text { women in } 15 \text { clinics }\end{array}$ & $\begin{array}{l}\text { IUD, Prenatal, } \\
\text { Gynecology, WTP for } \\
\text { shorter waiting times, } \\
\text { additional counseling }\end{array}$ & $\begin{array}{l}\text { FHI } \\
\text { PC } \\
\text { TFGI }\end{array}$ \\
\hline $\begin{array}{l}\text { Guatemala: APROFAM, 1999, } \\
\text { NGO clinic services }\end{array}$ & $\begin{array}{l}\text { Systematic clinic-based } \\
\text { samples; first survey } \\
\text { included } 4,856 \text { women in } \\
18 \text { clinics; the second, } \\
1,827 \text { in six clinics }\end{array}$ & $\begin{array}{l}\text { Prenatal, Gynecology, } \\
\text { Pap Smears, Supply } \\
\text { Contraceptives, Norplant }\end{array}$ & $\begin{array}{l}\text { FHI } \\
\text { PC }\end{array}$ \\
\hline $\begin{array}{l}\text { Mali: Pilplan, 1999, Contraceptive } \\
\text { Social Marketing Project }\end{array}$ & $\begin{array}{l}\text { Representative sample of } \\
2,780 \text { women and } 2,780 \\
\text { men }\end{array}$ & Supply Contraceptives & TFGI \\
\hline $\begin{array}{l}\text { Guatemala: Ministry of Health, } \\
\text { 2000, Hospital outpatient clinic and } \\
\text { policlinics }\end{array}$ & $\begin{array}{l}\text { Systematic sample of } 2,468 \\
\text { women in six clinics }\end{array}$ & $\begin{array}{l}\text { Female Sterilization, } \\
\text { Temporary } \\
\text { Contraceptives, } \\
\text { Ultrasound }\end{array}$ & $\begin{array}{l}\text { FHI } \\
\text { PC }\end{array}$ \\
\hline $\begin{array}{l}\text { Philippines: Well Family Midwife } \\
\text { Clinics, } 2000\end{array}$ & $\begin{array}{l}\text { Systematic sample of } 2,277 \\
\text { women in } 60 \text { clinics }\end{array}$ & $\begin{array}{l}\text { Pregnancy Tests, } \\
\text { Prenatal, Delivery, Pap } \\
\text { Smears, Temporary } \\
\text { Contraceptives }\end{array}$ & $\begin{array}{l}\text { FHI } \\
\text { PC }\end{array}$ \\
\hline
\end{tabular}

*TA (technical assistance): FHI = Family Health International, FRONTIERS Program; PC = Population Council INOPAL III or FRONTIERS Program; TFGI $=$ The Futures Group International. 


\section{Mali: Raising Prices for Existing Products}

The USAID-funded social marketing project in Mali launched a condom brand (Protector) in 1992 and an oral contraceptive (Pilplan) in 1993. At the beginning of the project, prices were set at 100 Mali francs (MF) per cycle of Pilplan and MF50 for a three-pack of Protector, or approximately US\$0.17 and US\$0.09 respectively, in mid-1998.

The project design called for a pricing review at the end of 1998 to increase project sustainability and improve distribution. A WTP survey was fielded in three urban sites and their immediately surrounding rural areas, including Sikasso, Mopti, and the capital city of Bamako. Sikasso and Mopti were chosen because they represented the highest and lowest sales areas, respectively. The survey sample included 2,780 women ages $15-40$ and 2,750 men ages $15-45$. It was stratified by city and urban-rural; within strata, enumeration areas were selected randomly.

The sequence of questions for current users of pills, injectables, and condoms followed the order described in Figure 3, page 6. Women who were not currently using pills or injectables were asked if they might use either of these methods in the future; similarly, men who were not currently using condoms were asked if they would use condoms in the future. A maximum price was calculated for each respondent who either was currently using or was a potential user of each method.

\section{Oral contraceptives}

Of 2,780 sexually active women interviewed, 390, or 14 percent, reported they were currently using oral contraceptives. Virtually all current pill users were able to provide details of their most recent supplyonly five $(1.3 \%)$ could not name their current pill brand and another five were unable to state the last price paid. The social marketing brand, Pilplan, was the clear market leader, accounting for 71 percent of the current users. Most Pilplan users (65\%) cited a pharmacy as their most recent source of supply; among these women, 98 percent reported that they had paid 100 francs (MF) for one cycle of pills, the established retail price.

All current pill users were able to answer the first hypothetical price increase - 79 percent said they would accept a MF100 price increase and 21 percent said they would not. After responding to two direct pricing questions, all were asked to name the highest price they were willing to pay. This maximum price was compared with the highest price increase the respondent said she would accept. To be internally consistent, the maximum price should be equal to or higher than the highest accepted price increase (plus original price paid); 93 percent of the respondents gave an internally consistent response ( $45 \%$ held at the last price asked and $48 \%$ cited an even higher price).

Female literacy is low in Mali; only 60 percent of current pill users stated that they had ever attended school. Nonetheless, schooling was not associated with ability to respond to the questionnaire. Women who had not attended school were no less likely to know the price of their oral contraceptives than women who had attended school ( $1 \%$ vs. $2 \%)$ and were only slightly more likely to give internally inconsistent responses to the WTP questions ( $8 \%$ vs. $4 \%, \mathrm{p}<.07$ ).

A few current pill users stated that their last source of supply was not their usual source ( 7 respondents, or $2 \%$ ). They were removed from further analysis, as were users who could not state the last price paid or who gave internally inconsistent answers. Willingness to pay was analyzed among the 92 percent of current pill users who met all eligibility criteria (e.g., consistent source of supply, ability to state last price paid, and internally consistent price responses). They were classified into three SES categories based on 
ownership of durable goods and education. ${ }^{8}$ Figure 4 compares WTP among current urban pill users by SES. While the differences are not large, it should be noted that the highest SES women were more likely to accept hypothetical price increases throughout the entire price range than the lowest SES respondents.

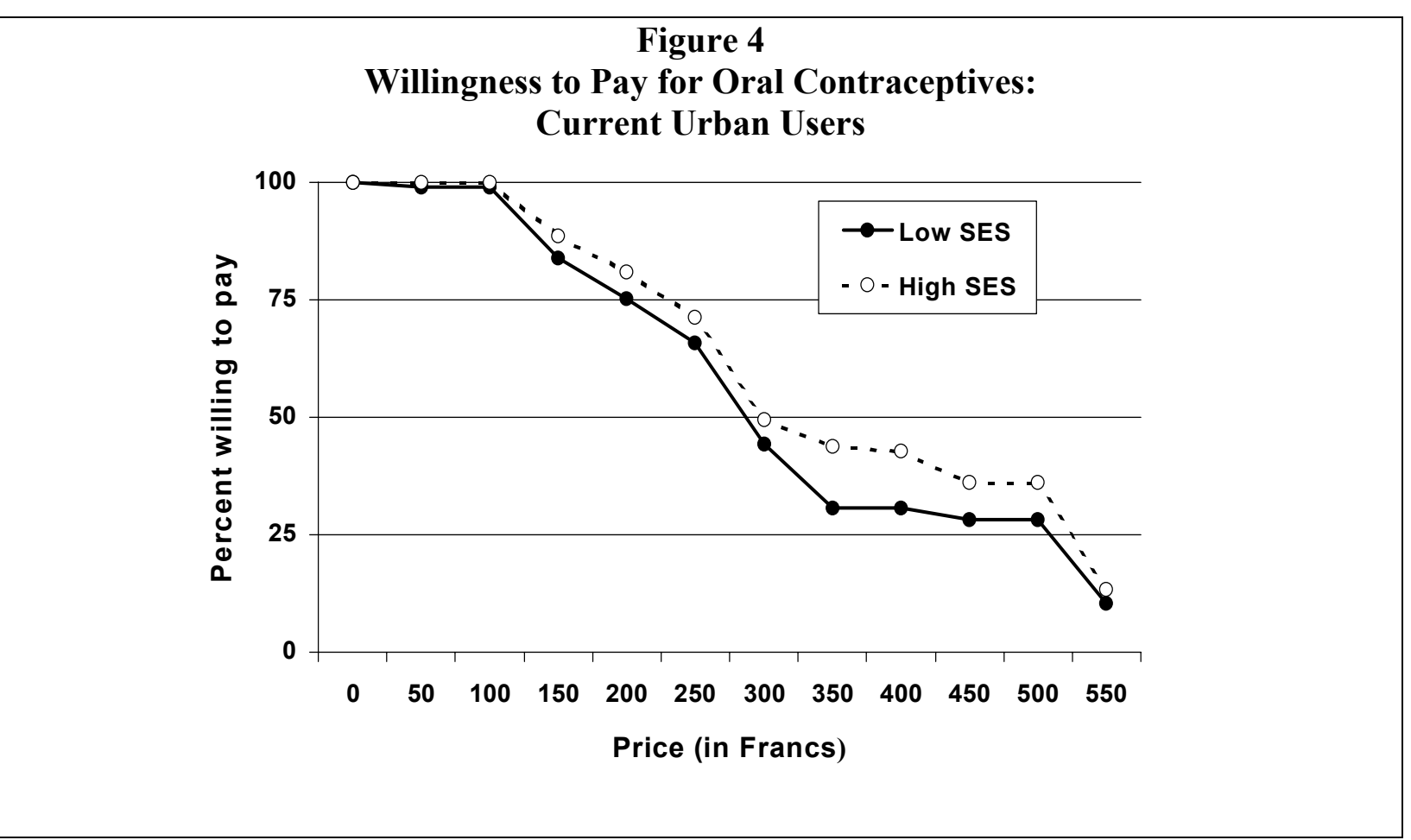

WTP was also assessed among potential pill users. These included women who were not currently using pills, injectables, or surgical contraception and who answered that they might start or resume using pills in the future; 736 women were classified as potential users.

Only 13 respondents, or 2 percent of the potential users, were unable to state a price that they were willing to pay for the method. Sixty-nine percent were willing to pay the highest price asked, MF250, and 58 percent of these went on to name a still higher price as the maximum they would be willing to pay.

Potential and current pill users showed nearly identical WTP at lower price levels, although at some of the higher prices WTP diminished slightly. However, among potential users, urban women show higher WTP than rural women, and higher SES urban women show higher willingness than lower SES urban women, as shown in Figure 5.

\footnotetext{
${ }^{8}$ Different criteria were used for urban and rural women. The absolute differences between the categories are relatively small; most families, even in urban Mali, would be considered fairly poor.
} 


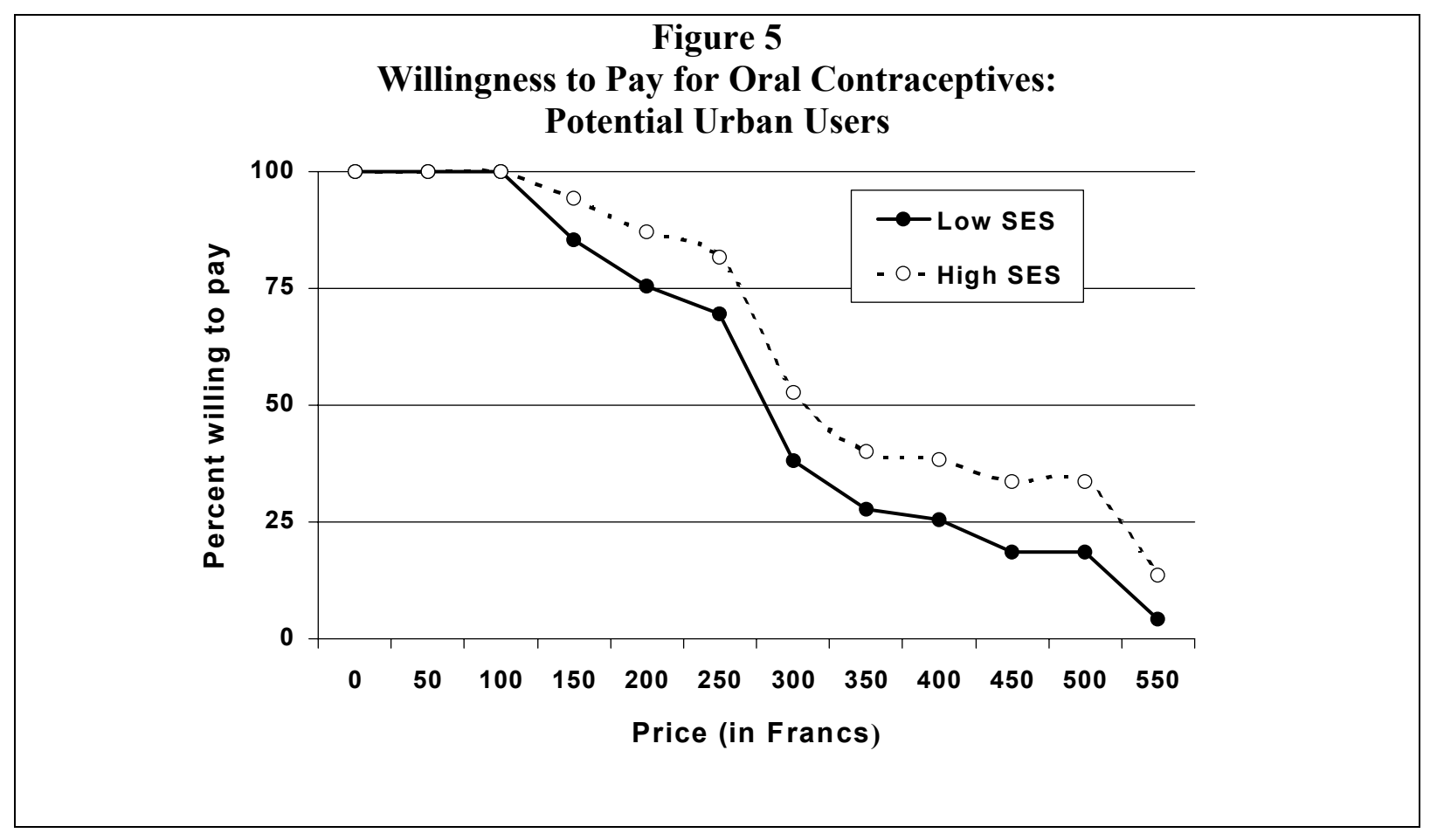

Figure 6 presents expected revenues for Pilplan at different prices. Total sales in 1998 were 761,200 cycles, representing 76 million at the current price of MF100. The highest price directly probed was MF250. Even with the expected loss of one-third of current Pilplan clients, this represents a potential revenue of MF128 million, or a MF68 million increase over current revenues. In other words, the expected loss in sales would be more than compensated for by the higher price. The dotted line in Figure 6 represents the prices at which the estimates of willingness to pay are no longer reliable.

\section{Figure 6}

\section{Expected Revenue from Oral Contraceptives}

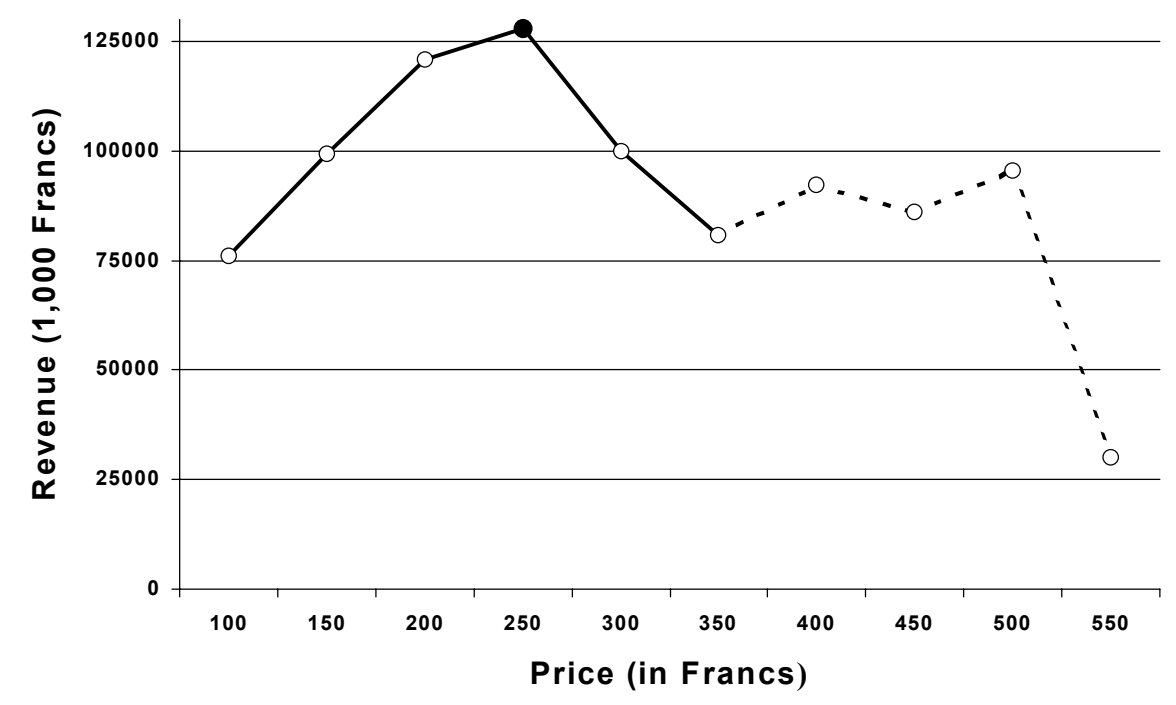




\section{Condoms}

Male respondents who answered that they had used a condom in the three months prior to the interview were classified as current condom users. A total of 742 respondents, or 27 percent, of the sample met this criterion. The Protector brand was the market leader in all areas, accounting for 90 percent of the most recent condom use. However, compared to female pill users, male condom users showed lower brand and source consistency -25 percent of current users responded that they often used another brand and/or a different source. This difference between methods is not surprising, given that condom use may be more sporadic than pill use; when asked with whom they had used a condom the last time, 46 percent of the respondents named an "occasional partner," including 36 percent of married men and 47 percent of those in a cohabiting union. When asked why they used condoms, 73 percent of current users cited only disease prevention and only 7 percent cited contraception; the remaining 20 percent cited both disease and pregnancy prevention.

Few respondents had difficulty answering current price or hypothetical WTP. Eight percent did not know their last brand and/or price; men who had had schooling were somewhat less likely to know brand and price than men who had never attended school $(9.5 \%$ vs. $4.9 \%$; $<<.07)$. All current users were able to answer the hypothetical price probes. Sixty-nine percent of current users accepted the highest price increase asked, and 81 percent of these named a still higher price that they would be willing to pay. Seven percent cited a maximum price willing to pay that was lower than the highest price agreed to. Although overall levels were low, schooling was related to internal inconsistency of response; 12 percent of men without schooling gave internally inconsistent answers versus 6 percent of men who had attended school $(\mathrm{p}<.01)$.

A total of 873 men, or 43 percent, of those who had not used a condom in the last three months responded that they would be interested in using condoms in the future. Fewer than one percent of these potential users could not state a price that they were willing to pay. Seventy-nine percent of potential condom users accepted the highest price asked MF150, and 71 percent of these named an even higher price that they would be willing to pay.

As was observed among urban pill users, high SES urban condom users showed consistently higher willingness to pay than low SES urban condom users, although the magnitude of the differences was not large. These findings are illustrated in Figure 7. Among potential condom users, urban men were more willing to pay than rural men; and among urban potential users, high SES men showed fairly substantial differences in willingness to pay compared to low SES men. An unexpected finding was that potential condom users showed higher predicted demand in the lower price range than current condom users. 


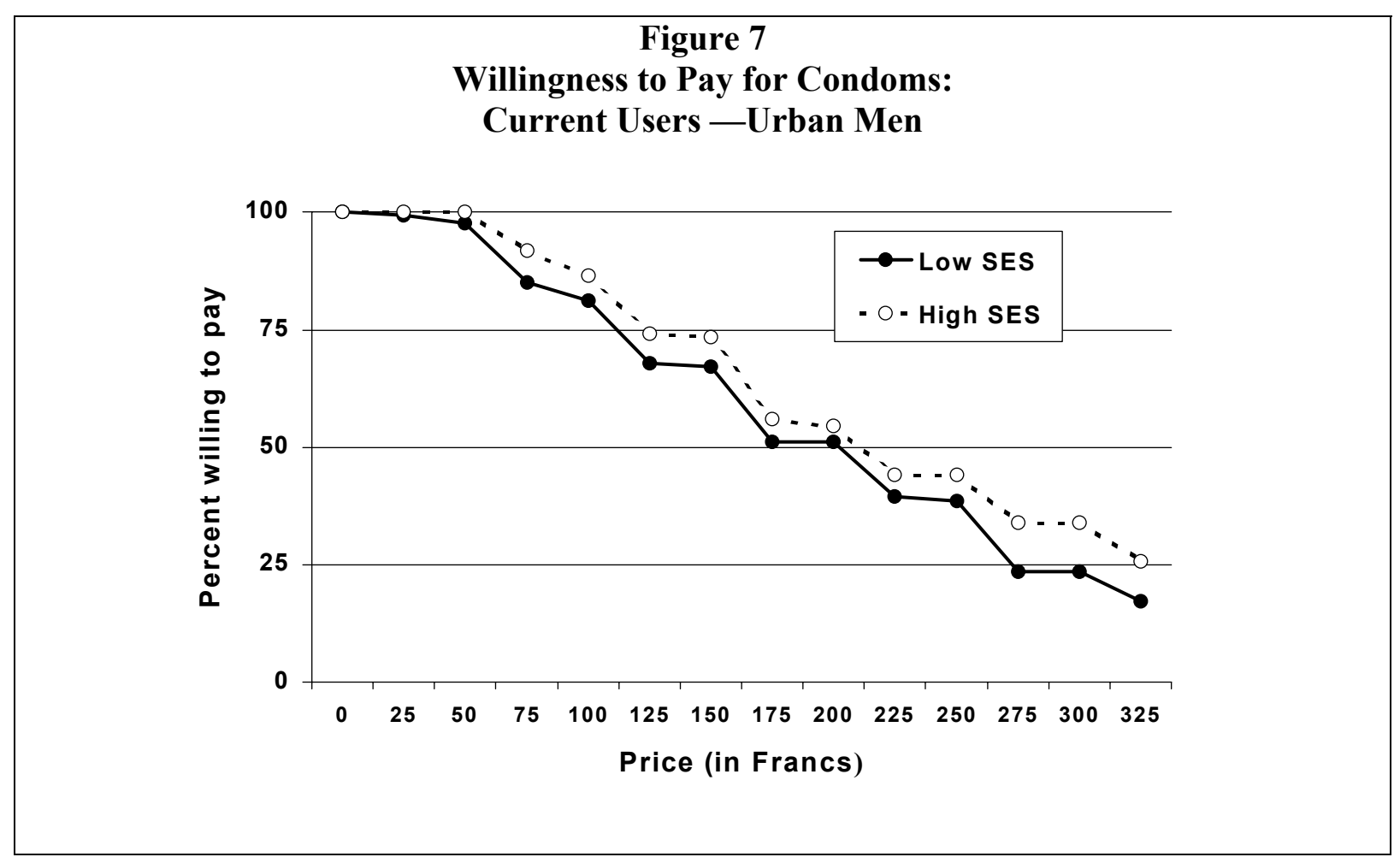

Also, as was observed for oral contraceptives, the highest potential revenue point for condoms corresponded to the highest price probed-MF150 for a packet of three condoms. Figure 8 presents the predicted revenue curve for Protector brand. Note that revenues would more than double if prices were raised from MF50 to 150, from MF85 million to MF176 million. As in Figure 6, the dotted line represents prices at which the estimates of willingness to pay are no longer reliable.

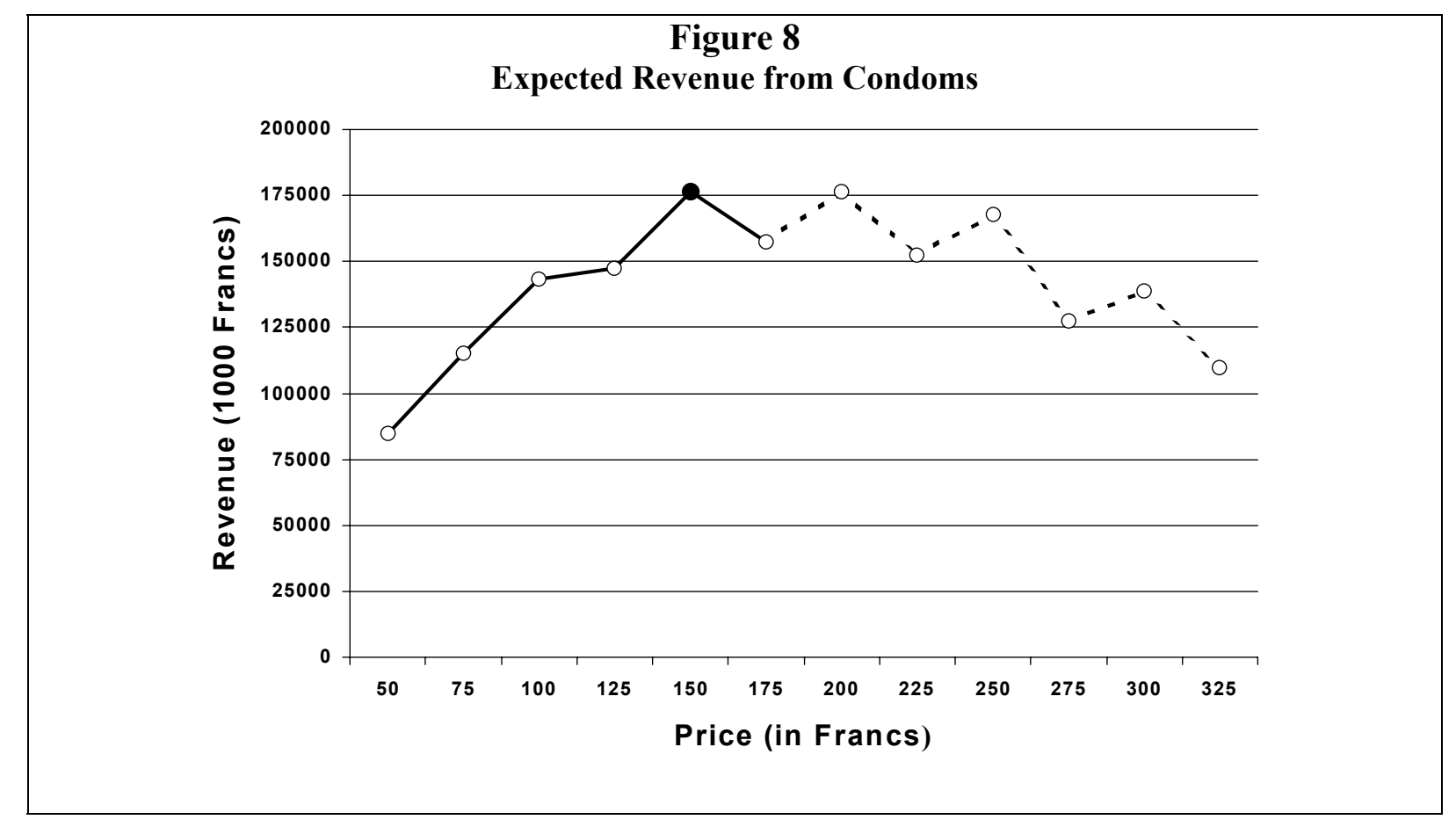


What can we conclude from the Mali application of the willingness to pay methodology?

1. Even in an area of low literacy, current users of different contraceptive methods can understand and respond coherently to questions about what they might do under different hypothetical conditions. Virtually all respondents - both current users and potential users - could give a yes or no answer to the initial hypothetical price question.

2. Asking respondents the maximum price they would be willing to pay significantly extends the range of potential prices among respondents who accept the highest price probed. Respondents who reject one or more of the price probes are less likely to offer a maximum price higher than the last price they accepted. Including the maximum price question also offers an internal check on respondents' understanding of the hypothetical questions. Few respondents give internally inconsistent answers to this question, although those without formal education are somewhat more likely to show confusion than those who have attended school.

3. Internal validity was generally high; higher SES respondents showed higher WTP than lower SES respondents, and among potential users, urban respondents showed higher WTP than rural respondents. Current and potential users did not differ consistently in their WTP.

\section{Pakistan: Setting Prices for New Products}

Setting prices for new social marketing products presents several challenges. First, since the product is new to the market, no specific data exist to guide decisionmaking. Second, even in the case where similar goods or services exist in the public or commercial sectors, the new product may be so different in its dosage, mode of delivery, and so forth, that existing information does not provide a useful comparison. WTP surveys can yield useful information in this situation as well, as shown by research in Pakistan.

The Pakistan Private Sector Population Project (PPSPP) was launched in two cities: Faisalabad and Larkana. The project design called for pills and injectables at subsidized prices that would be below fully commercial prices. WTP surveys were conducted in the two target cities in August 1996. A rural area was added to the sample because the government of Pakistan was concerned about pricing issues for public sector contraceptives in rural areas.

The target market for the PPSPP was married couples with monthly income between 1,500 rupees (PR) and PRs4,000 (US\$43-113). Likely acceptors of social marketing products were thought to be women younger than 40 years with at least one living child. The WTP survey sample was drawn from electoral wards in urban Faisalabad and Larkana where the majority of the respondents had the target income level. The rural sample was chosen from villages within five to $25 \mathrm{kms}$ of the city limits of Faisalabad, which were likely to fall within the target income range. Only women who met the age and parity requirements were interviewed. Four prices were asked: PRs 25, 15, 10, and 3, in decreasing order. The WTP price setting technique was still being developed in 1996, and the maximum price question was not included in the questionnaire.

A total sample of 1,753 women was interviewed. Although only 2 percent of the sample currently used oral contraceptives, another 6 percent responded that they might consider using pills in the future. Women whose first method choice was pills were classified as having a strong motivation to use the method, while women whose first method choice was a different method were classified as having a weak motivation to use that method. Strength of motivation was clearly associated with WTP; women whose 
first choice was pills were more willing to pay any given price than women whose first choice was not pills, as can be seen in Figure 9.

\section{Figure 9 \\ Willingness to Pay for Oral Contraceptives: Potential Users}

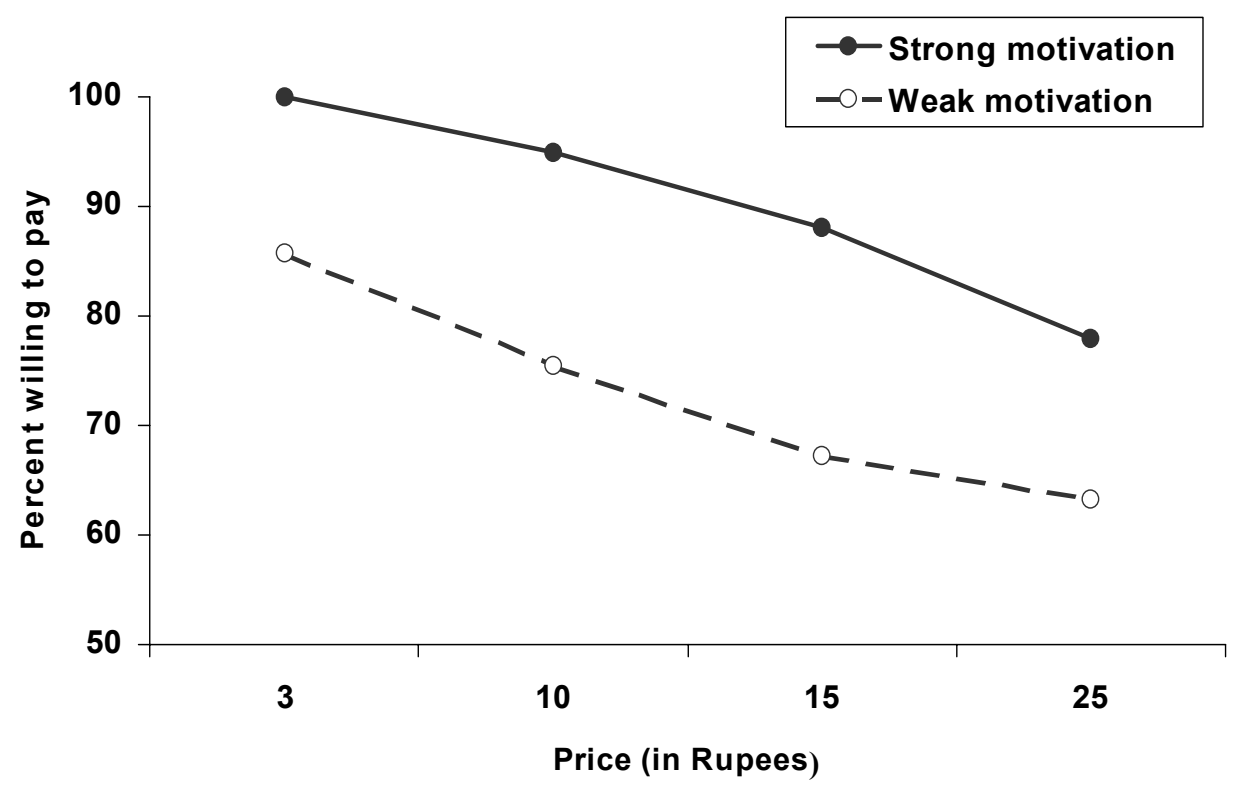

Following the WTP survey, the price of the socially marketed pill brand was set at PRs 15 per cycle, which 88 percent of the likeliest pill purchasers were willing to pay.

Unlike the Mali application, which was designed to test WTP for existing products, the Pakistan study was designed to inform price setting for new products. The methodological lessons learned in Pakistan reinforce and expand on the Mali case, as follows:

1. Nonusers of the method in question are able to answer WTP questions. Again, the rates of don't know responses were very low, and interviewers did not report problems in administering the questionnaire.

2. The recommended prices derived from the direct estimation of WTP fall within commonly used criteria of ability to pay (expressed as a percentage of household income) and are consistent with respondents' reported expenditures on preventive health care. ${ }^{9}$

3. Internal validity of the WTP methodology was supported; current nonusers with a stronger interest in using pills were more willing to pay than less motivated women.

\footnotetext{
9 "Conventional wisdom" suggests that social marketing prices for contraception should represent 1-3 percent of target users' income. At PRs15 per cycle, one year's worth of contraceptive protection (PRs195: PRs15 x 13 cycles) represents 1.3 percent or less of monthly household income in the target market segment (PRs1,500-4,000). Among women potentially interested in oral contraception, median annual household expenditures on preventive medicine were PRs300, one-half as high as a year's contraceptive protection. The price of the three-month injectable was set at PRs60, which represents no more than 1.6 percent of annual household income for one year of contraceptive protection; 80 percent of potential users were willing to pay this price.
} 


\section{Ecuador: Raising Prices for Services ${ }^{10}$}

The first two case studies demonstrate the internal consistency and reliability of the WTP technique. But how confident can a program manager be that the results of a WTP survey will, in fact, predict whether his or her clients will pay a new price? In other words, how valid is the methodology?

The following case study attempts to answer this question.

The study was conducted with Centros Medicos de Orientacíon y Planificacíon Familiar (Medical Center for Counseling and Family Planning, known by its Spanish acronym CEMOPLAF), an Ecuadoran NGO, which provides a range of reproductive health services. CEMOPLAF clients are primarily working-class urban women, 20 percent of whom live at or below the poverty line. To compensate for inflation, CEMOPLAF periodically increases prices on the order of 20 percent. Despite these increases and efforts to control costs and attract new clients, CEMOPLAF needed more revenue and in 1996 decided to test price increases greater than the usual 20 percent.

Fifteen of CEMOPLAF's 21 clinics serving clients with similar socioeconomic profiles participated in an experiment of three different price increases, preceded by a WTP baseline survey. ${ }^{11}$ Changes in clinic utilization following the price increases were compared to changes predicted by the survey.

The baseline survey was conducted two months prior to the scheduled price increases. Clinic clients arriving for obstetrics/gynecology, IUD revisits, and prenatal care were asked about their willingness to accept hypothetical price increments for their service. As in Mali, respondents were presented with a moderate price increase $(4,500$ sucres $(\mathrm{S} /)$, or US\$1.37), which was then raised (S/9,000 or US\$2.74) or lowered (S/2,500 or US\$0.76) depending on the response. Respondents who accepted the highest price increase were asked to name the highest price they would pay.

A total of 3,661 clinic clients was interviewed, of whom roughly one-third were there for IUD revisits, more than one-half for gynecology consultations, and about 12 percent for prenatal checkups. Overall, 79 percent accepted the medium price increase, and 53 percent accepted the highest price increase. There were no differences between services. Furthermore, 59 percent of those who accepted the highest price increase cited a still higher maximum price they would be willing to pay.

Figure 10 presents WTP for the three clinical services. Note that predicted demand for gynecology and prenatal services is virtually identical, and that demand for IUD revisits is parallel but somewhat lower. CEMOPLAF charges higher prices for gynecology and prenatal services to subsidize IUD services; the median initial price for gynecology and prenatal services was $S / 8,000$, compared to $S / 6,500$ for IUD revisits.

\footnotetext{
${ }^{10}$ For details of the study, see de Vargas et al. (1998).

${ }^{11}$ A cluster analysis was performed to identify clinics serving clientele with similar socioeconomic characteristics. It was based on four variables: percentage of clients working for pay outside the home, percentage who owned a refrigerator, percentage who had consumed meat on at least two of the three previous days, and median family income (see Bratt et al. 1998).
} 


\section{Figure 10 \\ Willingness to Pay for Clinical Services}

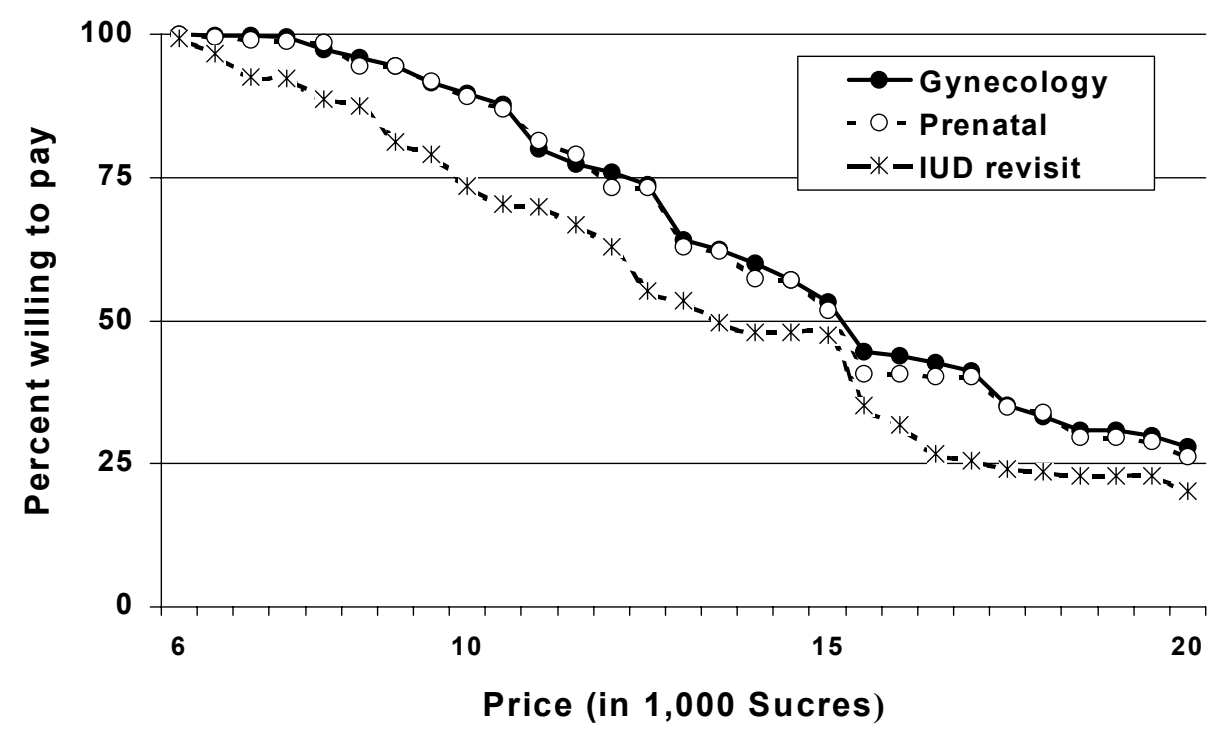

Predictive validity. Two months following the WTP survey, the 15 clinics that participated in the survey randomly instituted different price increases $(20 \%, 40 \%$, or $60 \%)$ for IUD revisits, gynecology consultations, and prenatal checkups. Mean monthly client volume during the three months preceding the price increases was compared to mean monthly client volume following the price increase.

Figure 11 presents predicted and observed demand for the three clinical services following the price change. ${ }^{12}$ Note the close correspondence between predicted and observed demand for IUD revisits and gynecology. For both of these services, observed demand decreased with increasing price; however, the inter-price differences were not statistically reliable. WTP predictions were less accurate for prenatal services, and, paradoxically, the highest post-price increase in demand was observed at the highest price change. Again, the observed inter-price differences failed to show statistical reliability.

\footnotetext{
12 The aggregate demand curves shown in Figure 10 were used to calculate demand for each service at each clinic at its new price, using the methodology described in Section III. Figure 11 presents predicted demand as a percentage of baseline volume (e.g., the ratio of the aggregate demand at the new price divided by the aggregate demand at the original price.)
} 


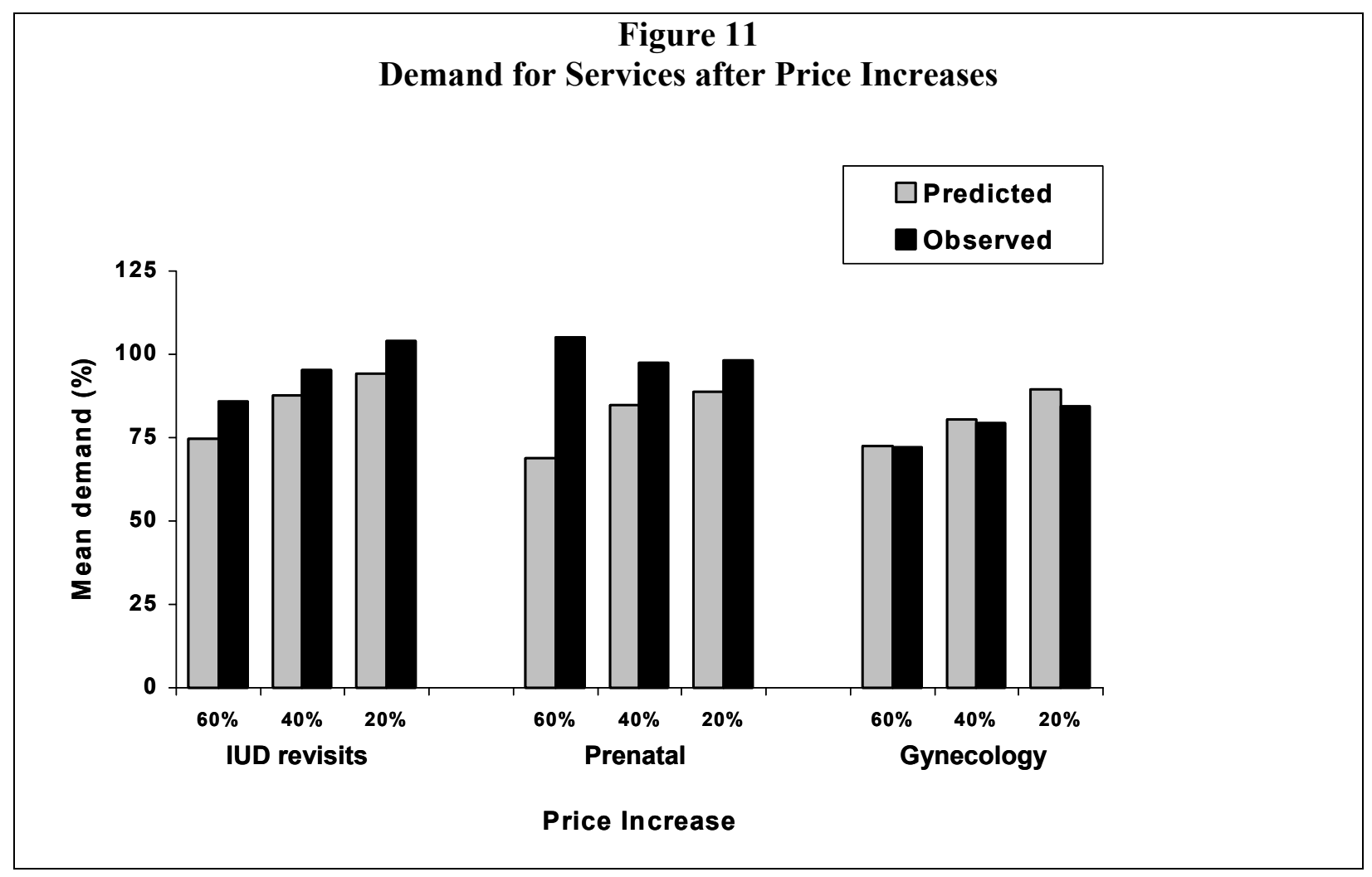

Analysis of client volume (number of consultations) following price increases showed that predicted percentage change was within \pm 5 percent of observed percentage change in 12 of 44 clinic-service combinations $(27 \%)$, and was within \pm 10 percent of observed percent change in 21 (48\%) cases. Finally, the WTP predictions overestimated client loss (i.e., predicted greater loss than actually observed) in 68 percent of the cases. Client loss was underestimated by less than 5 percent in an additional 14 percent of cases. Figure 12 shows the distribution of over- and underestimated client loss, demonstrating that the direct estimation technique helps protect programs from underestimating client loss. 


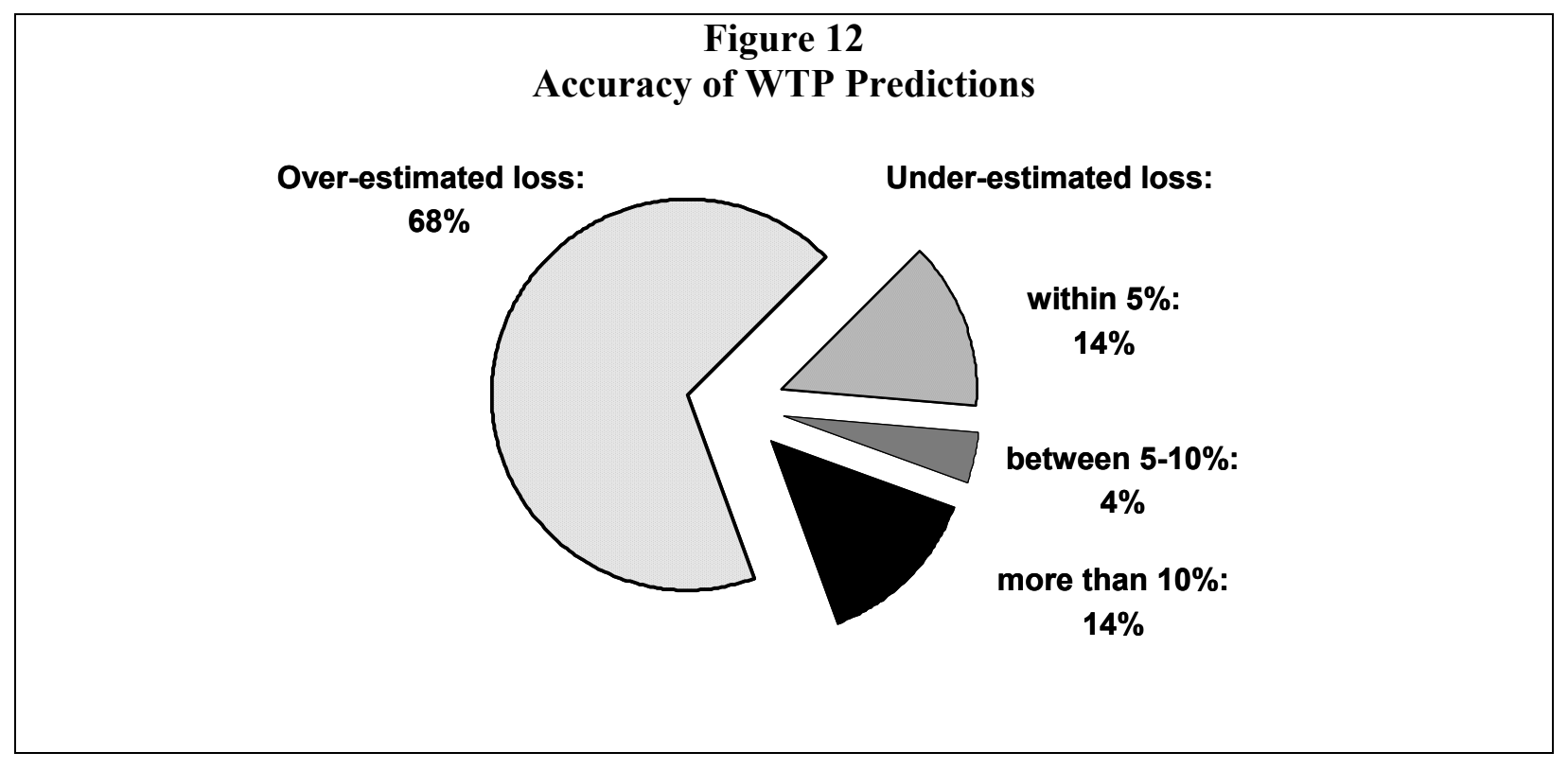

WTP estimates were a better predictor of post-price increase service volume than other variables available to program managers, such as initial service volume or magnitude of the price increase. As a conservative test of predictive validity, hierarchical multiple regression was used, entering first baseline clinic volume, price increase, and then the WTP predictions. Not surprisingly, future volume was almost perfectly correlated with baseline volume $\left(\mathrm{R}^{2}=.93\right)$. However, the WTP predictions significantly improved the prediction of change from baseline levels, from $\mathrm{R}^{2}=.095$ for baseline volume alone to $\mathrm{R}^{2}=.331$. Regardless of the dependent variable, price increases never predicted future performance.

The Ecuador study reinforces the lessons learned in Mali and Pakistan and adds a methodology for experimentally validating the estimates derived from WTP questionnaires:

1. Clinic clients had little difficulty answering questions about hypothetical price increases or the maximum price they were willing to pay. The inclusion of the maximum price question expanded the range of potential price increases without significantly lengthening the questionnaire.

2. The experimental validation of three price increases was consistent with the prediction of decreasing demand with increasing prices. The WTP estimates significantly improved managers' ability to predict the impact of the price changes. The systematic tendency to overestimate the decline in demand after a price increase makes WTP surveys especially useful for price setting in the not-forprofit sector where the need to maintain caseloads dictates the use of a conservative method of estimation. 


\section{Testing Predictive Validity}

To date, the only published predictive validity of WTP surveys in reproductive health is the CEMOPLAF study in Ecuador. More testing of predictive validity needs to be done. But different methodological considerations apply for different WTP applications.

Testing price increases for current users of products or services. Depending on the service or product, one of two approaches may be used. The first approach uses data from current clients to predict the behavior of future clients. It assumes that both current and future clients are drawn from the same population and have similar ability and willingness to pay. In this approach, predictive validity is assessed through the following steps: (1) baseline information on utilization is collected, usually through service statistics or sales data; (2) a WTP survey is conducted to obtain predicted utilization data; (3) prices are randomly increased in subsets of clinics (validation by multiple regression analysis, as in the CEMOPLAF study, requires at least two price levels); and (4) the accuracy of the prediction is compared with observed utilization, which is measured through post price-increase service statistics data. The number of observations can be maximized by using clinic-service combinations as the unit of analysis. (For example, if prices are to be increased for four services in 10 clinics, the number of observations is 4 $\mathrm{x} 10=40$.) The researcher should use as large a number of cases as possible because programs are very "noisy" with a great deal of variability. Both clinics and services often display seasonality, and the timing of seasons may vary by individual clinic and service. Some clinics may have a trajectory characterized by increasing utilization over time, while others may be characterized by decreasing or flat utilization.

The second possibility for assessing the predictive validity of the WTP survey occurs when the behavior of individual users can be tracked over time. The most stringent validity test for a given survey is to compare its results with respondents' subsequent behavior. For example, Griffin et al. (1995) asked respondents in India if they would be willing to pay a connection fee and monthly charges for an improved water system. After the water system was improved, households in the survey were reinterviewed. Ninety-one percent of the families who said they would connect to the water system in 1988 actually did so in 1991, and 94 percent of the families who said they would not, did not. Opportunities to conduct longitudinal studies are relatively rare in reproductive health programs, partly because of the time and effort involved and partly because many reproductive health services and products are not used consistently over relatively long periods. For example, prenatal clients will stop returning to the clinic after their baby is born, and IUD acceptors may need only few and infrequent checkups during many years of method use.

Setting prices for new products or services. The predictive validity of the WTP techniques when used for setting prices for new reproductive health products or services appears never to have been tested. In some situations, it may be possible to use a longitudinal approach, like the one reported by Griffin et al. (1995). But for most products and services, such an approach will not be possible. The problems that must be solved before the predictive validity of WTP surveys for new products can be validated include lack of baseline data for comparison purposes and the fact that the uptake of a new product or service can be influenced by a large number of factors other than price. 


\section{Bibliography}

Aker, B., M. Boroush, and S. Smith. 1989. "The Choice to Contracept in Liberia: Sensitivities to Changes in Incomes and Contraceptive Prices." SOMARC Report. Washington D.C.: The Futures Group International.

Akin, John S. and Brad Schwartz. 1988. "The Effect of Economic Factors on Contraceptive Choice in Jamaica and Thailand: A Comparison of Mixed Multinomial Logit Results," Economic Development and Cultural Change 36(3): 503-527.

Bratt, John H., James Foreit, and Teresa de Vargas. 1998. "Three Strategies to Promote Sustainability of CEMOPLAF Clinics in Ecuador," Studies in Family Planning 29(1): 58-68.

Foreit, J.R. \& Foreit, K.G. 2003. The reliability and validity of willingness to pay surveys for reproductive health pricing decisions in developing countries. Health Policy 63 (1): 37-47.

Griffin, C., J. Briscoe, B. Singh, R. Ramasubban, and R. Bhatia. 1995. "Contingent Valuation and Actual Behavior: Predicting Connections to New Water Systems in the State of Kerala, India," The World Bank Economic Review 9(3): 373-395.

Jensen, Eric R., N. Kak, K. Satjawinata, D.N. Wirawan, N. Nanjoy, and Suproyoko. 1993. “Contraceptive Pricing and Prevalence: Family Planning Self-Sufficiency in Indonesia," paper presented at the annual meeting of the Population Association of America, Cincinnati, Ohio.

Leon, Federico R. and Augustin Cuesta. 1993. "The Need for Quasi-Experimental Methodology to Evaluate Pricing Effects," Studies in Family Planning 24(6), part 1:375-381.

Lewis, Maureen A. 1986. “Do Contraceptive Prices Affect Demand?" Studies in Family Planning (17)3: 126-135.

National Institute of Population Studies and IRD/Macro International. 1992. Pakistan Demographic and Health Survey 1990/1991. Columbia, MD: National Institute of Population Studies (Pakistan) and IRD/Macro International Inc.

Oliver, Raylynn. 1994. "The Effect of the Quality, Price, and Availability of Family Planning on Contraceptive Use in Ghana.” Living Standards Measurement Working Paper, World Bank, Africa Technical and Policy Research departments. Washington, D.C.: World Bank.

Phillips, Kathryn A., Rick K. Homan, Harold S. Luft, Patricia H. Hiatt, Kent R. Olson, Thomas E. Kearney, and Stuart E. Heard. 1997. "Willingness to Pay for Poison Control Centers," Journal of Health Economics 16: 347.

Portnoy, Paul R. 1994. "The Contingent Valuation Debate: Why Economists Should Care," Journal of Economic Perspectives (8)4: 3-17.

de Vargas, Teresa, John H. Bratt, Varuni Dayaratna, James R. Foreit, and Daniel H. Kress. 1998. "Estimating Consumer Response to Price Changes in Family Planning and Reproductive Health Services," paper presented at the annual meeting of the Population Association of America, Chicago, Illinois. 


\section{APPENDIX I MODEL QUESTIONNAIRES \\ Model for Current and Potential Users of Clinical Services (Facility Exit Interview) \\ Household Survey for Condom Users and Potential Users (Household Interview)}




\section{Reproductive Health \\ Willingness to Pay \\ Model Questionnaire for Facility Exit Interviews}

\section{Informed Consent}

The first tasks facing the interviewer are to introduce herself, inform the potential respondent about the objectives, risks and benefits of the research, and obtain the consent of the respondent to be interviewed. Most research organizations require that the interviewee give informed consent. Informed consent derives from medical research where there are risks and benefits. Consent forms should use simple sentences and direct statements, appropriate to the literacy or educational level of the setting. The study participant must have an opportunity to ask questions and be fully informed before signing the consent form. Where informed consent is required, the following elements must be included:

1. Purpose of study.

2. Risks to the study participant, including physical, social, and emotional.

3. Benefits to the study participant, including, if necessary, a statement that there are none.

4. Information on confidentiality, including the use of identifiers and access to personal data.

5. Place to go with questions or problems at any time.

6. Information regarding withdrawal from the study. The study participant has the right to leave at any time without penalty.

7. Guarantee that services are available whether or not the potential respondent agrees to participate in the study, or if $\mathrm{s} /$ he withdraws.

8. Information on study procedures and duration.

In terms of placement, the form should be on a separate sheet of paper. Note that the researcher must be able to link the informed consent form to the relevant questionnaire with a numerical indicator. For data collection that represents low risk, oral consent is sufficient, but the form should be signed by the interviewer as part of the documentation.

Different organizations have different ways of assuring informed consent. The questionnaire contains one example of an informed consent statement. 


\section{Reproductive Health \\ Willingness to Pay \\ Model Questionnaire for Facility Exit Interviews}

MODEL FOR CURRENT AND POTENTIAL USERS OF CLINICAL SERVICES

[INSTRUCTIONS TO THE INTERVIEWER: The following statement should be read to every potential interviewee.] May I have a minute of your time, please? AGENCY wants to continue providing you with convenient, high quality services. In order to do this, it will be necessary for AGENCY to raise the prices of some services. We want to know how you will be affected by these price changes. There are no right or wrong answers, so please be honest and tell us what is true for you. The information being collected is for planning purposes only and there are no personal risks or benefits to your participation. I do not need to know your name and address. Everything that you say will be confidential, and the only identifier on the questionnaire will be a number, not your name. No one, including the staff of this clinic, will be told what you personally have told us, and no one will be given your name. The services will be available to you whether or not you agree to participate in this study. The interview takes about fifteen minutes. You can terminate the interview whenever you want without consequences. Do you have any questions? Would you like to participate? If you would like to know more about this study, please contact at
1. Participation
YES (proceed to interview)
NO (thank respondent and wish her a nice day)

[All questionnaires will be saved by the interviewer regardless of the respondent's decision to participate or not to participate.]

2. Questionnaire Number: [_] [_] [_] [_]

3. Clinic Number: [__ ] $]$

4. Interviewer Name:

5. Interview Date: Mo. Day__ Yr.

6. Time Interview Began:

7. Time Interview Completed: 
A. Demographic Questions

\begin{tabular}{|c|c|c|c|}
\hline Q. & QUESTION & RESPONSE CODE & SKIP \\
\hline 100 & How old were you at your last birthday? & Years & \\
\hline 101 & What is your marital status? & $\begin{array}{ll}\text { Married/In-union } & 1 \\
\text { Widowed, Separated, Divorced } & 2 \\
\text { Single } & 3 \\
\end{array}$ & \\
\hline 102 & How many living children do you have? & $\begin{array}{l}\text { None } \\
\text { Number }\end{array}$ & GO TO 104 \\
\hline 103 & $\begin{array}{l}\text { How many living children do you have in the } \\
\text { following age groups? }\end{array}$ & $\begin{array}{ll}\text { AGE GROUP } & \text { NO. OF CHILDREN } \\
<1 & \\
1-3 & \\
4 \text { or older } & \\
\end{array}$ & \\
\hline 104 & $\begin{array}{l}\text { What is the highest grade/year you completed? } \\
\text { PROBE FOR THE HIGHEST YEAR } \\
\text { COMPLETED }\end{array}$ & 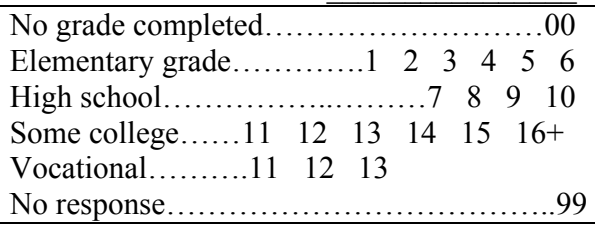 & \\
\hline
\end{tabular}

\section{B. Ability to Pay Questions}

\begin{tabular}{|c|c|c|c|c|}
\hline Q. & QUESTION & RESPONSE CODE & & SKIP \\
\hline 200 & $\begin{array}{l}\text { Does your household have: } \\
\text { Electricity } \\
\text { Piped water } \\
\text { Flush toilet } \\
\text { Radio } \\
\text { TV } \\
\text { VCR } \\
\text { Telephone } \\
\text { Car/pick-up truck }\end{array}$ & $\begin{array}{c}\text { YES } \\
1 \\
1 \\
1 \\
1 \\
1 \\
1 \\
1 \\
1\end{array}$ & & \\
\hline 201 & Do you work outside the home? & $\begin{array}{l}\text { Yes } \\
\text { No }\end{array}$ & $\begin{array}{l}1 \\
2 \\
\end{array}$ & GO TO 204 \\
\hline 202 & What type of job do you have? & Job & & \\
\hline 203 & How much do you make per month? & Amount & & \\
\hline 204 & What type of job does your spouse/partner have? & $\begin{array}{l}\text { Do not have partner } \\
\text { Job } \\
\text { Does not work }\end{array}$ & & $\begin{array}{l}\text { GO TO } 206 \\
\text { GO TO } 206\end{array}$ \\
\hline 205 & $\begin{array}{l}\text { How much does your spouse/partner make per } \\
\text { month? }\end{array}$ & Amount & & \\
\hline 206 & $\begin{array}{l}\text { Who provides monetary support for your family? } \\
\text { MONETARY SUPPORT INCLUDES } \\
\text { INCOME, GIFTS, ETC. }\end{array}$ & $\begin{array}{l}\text { Interviewee } \\
\text { Spouse/Partner } \\
\text { Children } \\
\text { Other }\end{array}$ & $\begin{array}{l}1 \\
2 \\
3 \\
4\end{array}$ & \\
\hline 207 & $\begin{array}{l}\text { What is your family's TOTAL income per } \\
\text { month? } \\
\text { PROBE FOR ALL SOURCES OF INCOME } \\
\text { (e.g. RENT, GIFTS, ETC.) } \\
\text { AMOUNT MUST BE GREATER THAN OR } \\
\text { EQUAL TO (Q203 + Q205) }\end{array}$ & Total ALL SOURCES & & \\
\hline
\end{tabular}


C. Type of Visit

\begin{tabular}{|c|c|c|c|c|}
\hline $\mathbf{Q}$. & QUESTION & RESPONSE CODE & & SKIP \\
\hline 300 & Is this your first visit to AGENCY? & $\begin{array}{l}\text { Yes } \\
\text { No }\end{array}$ & $\begin{array}{l}1 \\
2\end{array}$ & GO TO 302 \\
\hline 301 & $\begin{array}{l}\text { Is your visit today a "revisit" scheduled during } \\
\text { a previous appointment? }\end{array}$ & $\begin{array}{l}\text { Yes } \\
\text { No }\end{array}$ & $\begin{array}{l}1 \\
2\end{array}$ & \\
\hline 302 & What is the main service you received today? & $\begin{array}{l}\text { Gynecology } \\
\text { Injectable Contraceptive } \\
\text { IUD Insertion } \\
\text { IUD Revisit } \\
\text { Pill Visit } \\
\text { Prenatal Care } \\
\text { Other: specify }\end{array}$ & $\begin{array}{l}1 \\
2 \\
3 \\
4 \\
5 \\
6 \\
\\
88 \\
\end{array}$ & $\begin{array}{l}\text { GO TO } 400 \\
\text { GO TO } 500 \\
\text { GO TO } 600 \\
\text { GO TO } 700 \\
\text { GO TO } 800 \\
\text { GO TO } 900 \\
\text { GO TO END }\end{array}$ \\
\hline
\end{tabular}




\section{Willingness to Pay Questions: Current Users}

1. Gynecology

\begin{tabular}{|c|c|c|c|c|}
\hline Q. & QUESTION & \multicolumn{2}{|l|}{ RESPONSE CODE } & SKIP \\
\hline 400 & \multicolumn{3}{|c|}{$\begin{array}{l}\text { READ TO CLIENT: } \\
\text { The current price of a gynecology consultation is } \mathrm{I} / 10 \text { Intis. This is just the cost of the consultation, } \\
\text { your total cost may have been greater if other tests recommended by clinic personnel were } \\
\text { performed. }\end{array}$} & \\
\hline 401 & $\begin{array}{l}\text { Did you pay the consultation price posted } \\
\text { above? }\end{array}$ & $\begin{array}{l}\text { Yes } \\
\text { No }\end{array}$ & $\begin{array}{l}1 \\
2\end{array}$ & GO TO 404 \\
\hline 402 & How much did you pay? & Amount: & & \\
\hline 403 & $\begin{array}{l}\text { Why did you pay more/less than the posted } \\
\text { price? } \\
\text { DETERMINE IF DIFFERENCE IN PRICE } \\
\text { IS DUE TO PAYING FOR OTHER } \\
\text { SERVICES. IF YES, CONTINUE } \\
\text { INTERVIEW. IF NO, RECORD REASON } \\
\text { AND END INTERVIEW. }\end{array}$ & Reason: & & \\
\hline 404 & \multicolumn{3}{|c|}{$\begin{array}{l}\text { READ TO CLIENT: } \\
\text { I would now like to ask you some questions about your response to potential changes in the price of } \\
\text { this consultation fee. In answering these questions, please bear in mind the following: } \\
\text { 1. Assume that your income will stay the same even if AGENCY prices change. } \\
\text { 2. Alternatives do exist for AGENCY services (i.e., Ministry of Health, private clinic, etc.). }\end{array}$} & \\
\hline 405 & $\begin{array}{l}\text { Suppose that the price of a gynecology } \\
\text { consultation increased by } I / 5 \text { to } / / 15 \text {. Would } \\
\text { you use AGENCY for your gynecology visits if } \\
\text { the price were } I / 15 \text { ? }\end{array}$ & $\begin{array}{l}\text { Yes } \\
\text { No } \\
\text { Don't Know }\end{array}$ & $\begin{array}{l}1 \\
2 \\
99\end{array}$ & $\begin{array}{l}\text { GO TO } 407 \\
\text { GO TO } 407\end{array}$ \\
\hline 406 & $\begin{array}{l}\text { Suppose that the price of a gynecology } \\
\text { consultation increased even further-by } \mathrm{I} / 10 \text { to } \\
\mathrm{I} / 20 \text {. At this price would you use AGENCY for } \\
\text { your gynecology visits if the price were } \mathrm{I} / 20 \text { ? }\end{array}$ & $\begin{array}{l}\text { Yes } \\
\text { No } \\
\text { Don't Know }\end{array}$ & $\begin{array}{l}1 \\
2 \\
99\end{array}$ & $\begin{array}{l}\text { GO TO } 408 \\
\text { GO TO } 408 \\
\text { GO TO } 408\end{array}$ \\
\hline 407 & $\begin{array}{l}\text { Suppose that the price increase was less than } \\
\text { the previous amount. Suppose the price of a } \\
\text { gynecology consultation increased by } \mathrm{I} / 2 \text { to } \\
\mathrm{I} / 12 \text {. Would you use AGENCY for your } \\
\text { gynecology visits if the price were } \mathrm{I} / 12 \text { ? }\end{array}$ & $\begin{array}{l}\text { Yes } \\
\text { No } \\
\text { Don't Know }\end{array}$ & $\begin{array}{l}1 \\
2 \\
99\end{array}$ & \\
\hline 408 & $\begin{array}{l}\text { What would be the highest price you would be } \\
\text { willing to pay for gynecology services from } \\
\text { AGENCY? }\end{array}$ & Amount & & \\
\hline 409 & $\begin{array}{l}\text { If AGENCY increased the price of the } \\
\text { gynecology service beyond what you were } \\
\text { willing or able to pay, what would you do? }\end{array}$ & $\begin{array}{l}\text { Go without service } \\
\text { Go somewhere else } \\
\text { I don't know } \\
\text { Other: specify }\end{array}$ & $\begin{array}{l}1 \\
2 \\
99 \\
88\end{array}$ & $\begin{array}{l}\text { GO TO } 1000 \\
\text { GO TO } 410 \\
\text { GO TO } 1000 \\
\text { GO TO } 1000\end{array}$ \\
\hline 410 & $\begin{array}{l}\text { Where would you go? } \\
\text { DO NOT READ CHOICES } \\
\text { CODE ALL MENTIONED }\end{array}$ & $\begin{array}{l}\text { Public Sector } \\
\text { Other NGO } \\
\text { Private Sector } \\
\text { Pharmacy } \\
\text { Other: specify } \\
\text { I don't know }\end{array}$ & $\begin{array}{l}1 \\
2 \\
3 \\
4 \\
88 \\
99\end{array}$ & $\begin{array}{l}\text { GO TO } 1000 \\
\text { GO TO } 1000 \\
\text { GO TO } 1000 \\
\text { GO TO } 1000 \\
\text { GO TO } 1000 \\
\text { GO TO } 1000\end{array}$ \\
\hline
\end{tabular}


2. Injectable Contraceptive

\begin{tabular}{|c|c|c|c|c|}
\hline Q. & QUESTION & \multicolumn{2}{|l|}{ RESPONSE CODE } & SKIP \\
\hline 500 & \multicolumn{3}{|c|}{$\begin{array}{l}\text { READ TO CLIENT: } \\
\text { The current cost of the injectable contraceptive is } \mathrm{I} / 12 \text { Intis. This is just the cost of the consultation } \\
\text { and the injection, your total cost may be greater if other tests recommended by clinic personnel were } \\
\text { performed. }\end{array}$} & \\
\hline 501 & Did you pay the price posted above? & $\begin{array}{l}\text { Yes } \\
\text { No }\end{array}$ & $\begin{array}{l}1 \\
2\end{array}$ & GO TO 504 \\
\hline 502 & How much did you pay? & Amount: & & \\
\hline 503 & $\begin{array}{l}\text { Why did you pay more/less than the posted } \\
\text { price? } \\
\text { DETERMINE IF DIFFERENCE IN PRICE } \\
\text { IS DUE TO PAYING FOR OTHER } \\
\text { SERVICES. IF YES, CONTINUE } \\
\text { INTERVIEW. IF NO, RECORD REASON } \\
\text { AND END INTERVIEW. }\end{array}$ & Reason: & & \\
\hline 504 & \multicolumn{3}{|c|}{$\begin{array}{l}\text { READ TO CLIENT: } \\
\text { I would now like to ask you some questions about your response to potential changes in the price of } \\
\text { this consultation fee. In answering these questions, please bear in mind the following: } \\
\text { 1. Assume that your income will stay the same even if AGENCY prices change. } \\
\text { 2. Alternatives do exist for AGENCY services (i.e., Ministry of Health, private clinic, etc.). }\end{array}$} & \\
\hline 505 & $\begin{array}{l}\text { Suppose that the price of the injectable } \\
\text { contraceptive increased by } I / 5 \text { to } I / 17 \text {. Would } \\
\text { you come to AGENCY for your injection if the } \\
\text { price were } I / 17 \text { ? }\end{array}$ & $\begin{array}{l}\text { Yes } \\
\text { No } \\
\text { Don't Know }\end{array}$ & $\begin{array}{l}1 \\
2 \\
99\end{array}$ & $\begin{array}{l}\text { GO TO } 507 \\
\text { GO TO } 507\end{array}$ \\
\hline 506 & $\begin{array}{l}\text { Suppose that the price of the injectable } \\
\text { contraceptive increased even further, by } I / 10 \text { to } \\
\mathrm{I} / 22 \text {. Would you come to AGENCY for your } \\
\text { injection if the price were } \mathrm{I} / 22 \text { ? }\end{array}$ & $\begin{array}{l}\text { Yes } \\
\text { No } \\
\text { Don't Know }\end{array}$ & $\begin{array}{l}1 \\
2 \\
99\end{array}$ & $\begin{array}{l}\text { GO TO } 508 \\
\text { GO TO } 508 \\
\text { GO TO } 508\end{array}$ \\
\hline 507 & $\begin{array}{l}\text { Suppose that the price increase was less than } \\
\text { the previous amount. Suppose the price of the } \\
\text { injectable contraceptive increased by } \mathrm{I} / 3 \text { to } \mathrm{I} / 15 \text {. } \\
\text { Would you come to AGENCY for your } \\
\text { injection if the price were I/15? }\end{array}$ & $\begin{array}{l}\text { Yes } \\
\text { No } \\
\text { Don't Know }\end{array}$ & $\begin{array}{l}1 \\
2 \\
99\end{array}$ & \\
\hline 508 & $\begin{array}{l}\text { What would be the highest price you would be } \\
\text { willing to pay for the injectable contraceptive } \\
\text { from AGENCY? }\end{array}$ & Amount & & \\
\hline 509 & $\begin{array}{l}\text { If AGENCY increased the price of the } \\
\text { injectable contraceptive beyond what you were } \\
\text { willing or able to pay, what would you do? }\end{array}$ & $\begin{array}{l}\text { Not use a contraceptive method } \\
\text { Go somewhere else } \\
\text { Switch to a cheaper method } \\
\quad \text { Specify: } \\
\text { Other: specify } \\
\text { I don't know }\end{array}$ & $\begin{array}{l}1 \\
2 \\
3 \\
88 \\
99\end{array}$ & $\begin{array}{l}\text { GO TO } 1000 \\
\text { GO TO } 510 \\
\text { GO TO } 1000 \\
\text { GO TO } 1000 \\
\text { GO TO } 1000 \\
\text { GO TO } 1000\end{array}$ \\
\hline 510 & $\begin{array}{l}\text { Where would you go? } \\
\text { DO NOT READ CHOICES } \\
\text { CODE ALL MENTIONED }\end{array}$ & $\begin{array}{l}\text { Public Sector } \\
\text { Other NGO } \\
\text { Private Sector } \\
\text { Pharmacy } \\
\text { Other: specify } \\
\text { I don't know }\end{array}$ & $\begin{array}{l}1 \\
2 \\
3 \\
4 \\
88 \\
99 \\
\end{array}$ & $\begin{array}{ll}\text { GO TO } 1000 \\
\text { GO TO } 1000 \\
\text { GO TO } 1000 \\
\text { GO TO } 1000 \\
\text { GO TO } 1000 \\
\text { GO TO } 1000\end{array}$ \\
\hline
\end{tabular}


3. IUD Insertion

\begin{tabular}{|c|c|c|c|c|}
\hline $\mathbf{Q}$. & QUESTION & \multicolumn{2}{|l|}{ RESPONSE CODE } & SKIP \\
\hline 600 & \multicolumn{3}{|c|}{$\begin{array}{l}\text { READ TO CLIENT: } \\
\text { The current cost of an IUD insertion is } \mathrm{I} / 15 \text { Intis. This is just the cost of the consultation and the } \\
\text { IUD, your total cost may be greater if other tests recommended by clinic personnel were performed. }\end{array}$} & \\
\hline 601 & Did you pay the price posted above? & $\begin{array}{l}\text { Yes } \\
\text { No }\end{array}$ & & GO TO 604 \\
\hline 602 & How much did you pay? & Amount: & & \\
\hline 603 & $\begin{array}{l}\text { Why did you pay more/less than the posted } \\
\text { price? } \\
\text { DETERMINE IF DIFFERENCE IN PRICE } \\
\text { IS DUE TO PAYING FOR OTHER } \\
\text { SERVICES. IF YES, CONTINUE } \\
\text { INTERVIEW. IF NO, RECORD REASON } \\
\text { AND END INTERVIEW. }\end{array}$ & Reason: & & \\
\hline 604 & \multicolumn{3}{|c|}{$\begin{array}{l}\text { READ TO CLIENT: } \\
\text { I would now like to ask you some questions about your response to potential changes in the price of } \\
\text { this consultation fee. In answering these questions, please bear in mind the following: } \\
\text { 1. Assume that your income will stay the same even if AGENCY prices change. } \\
\text { 2. Alternatives do exist for AGENCY services. }\end{array}$} & \\
\hline 605 & $\begin{array}{l}\text { Suppose that the price of an IUD insertion } \\
\text { increased by } I / 5 \text { to } / 20 \text {, would you come to } \\
\text { AGENCY for your IUD insertion if the price } \\
\text { were } I / 20 \text { ? }\end{array}$ & $\begin{array}{l}\text { Yes } \\
\text { No } \\
\text { Don't Know }\end{array}$ & $\begin{array}{l}1 \\
2 \\
99\end{array}$ & $\begin{array}{l}\text { GO TO } 607 \\
\text { GO TO } 607\end{array}$ \\
\hline 606 & $\begin{array}{l}\text { Suppose that the price of an IUD insertion } \\
\text { increased even further, by } I / 10 \text { to I/25. Would } \\
\text { you come to AGENCY for your IUD insertion } \\
\text { if the price were I/25? }\end{array}$ & $\begin{array}{l}\text { Yes } \\
\text { No } \\
\text { Don't Know }\end{array}$ & $\begin{array}{l}1 \\
2 \\
99\end{array}$ & $\begin{array}{l}\text { GO TO } 608 \\
\text { GO TO } 608 \\
\text { GO TO } 608\end{array}$ \\
\hline 607 & $\begin{array}{l}\text { Suppose that the price increase was less than } \\
\text { the previous amount. Suppose the price of an } \\
\text { IUD insertion increased by } I / 3 \text { to I/ } 18 \text {. Would } \\
\text { you come to AGENCY for your IUD insertion } \\
\text { if the price were I/ } 18 \text { ? }\end{array}$ & $\begin{array}{l}\text { Yes } \\
\text { No } \\
\text { Don't Know }\end{array}$ & $\begin{array}{l}1 \\
2 \\
99\end{array}$ & \\
\hline 608 & $\begin{array}{l}\text { What would be the highest price you would be } \\
\text { willing to pay for an IUD insertion from } \\
\text { AGENCY? }\end{array}$ & Amount & & \\
\hline 609 & $\begin{array}{l}\text { If AGENCY increased the price of an IUD } \\
\text { insertion beyond what you were willing or able } \\
\text { to pay, what would you do? }\end{array}$ & $\begin{array}{l}\text { Not use a contraceptive method } \\
\text { Go somewhere else } \\
\text { Switch to a cheaper method } \\
\quad \text { Specify: } \\
\text { Other: specify } \\
\text { I don't know }\end{array}$ & $\begin{array}{l}1 \\
2 \\
3 \\
88 \\
99 \\
\end{array}$ & $\begin{array}{l}\text { GO TO } 1000 \\
\text { GO TO } 610 \\
\text { GO TO } 1000 \\
\text { GO TO } 1000 \\
\text { GO TO } 1000 \\
\text { GO TO } 1000\end{array}$ \\
\hline 610 & $\begin{array}{l}\text { Where would you go? } \\
\text { DO NOT READ CHOICES } \\
\text { CODE ALL MENTIONED }\end{array}$ & $\begin{array}{l}\text { Public Sector } \\
\text { Other NGO } \\
\text { Private Sector } \\
\text { Pharmacy } \\
\text { Other: specify } \\
\text { I don't know }\end{array}$ & $\begin{array}{l}1 \\
2 \\
3 \\
4 \\
88 \\
99\end{array}$ & $\begin{array}{l}\text { GO TO } 1000 \\
\text { GO TO } 1000 \\
\text { GO TO } 1000 \\
\text { GO TO } 1000 \\
\text { GO TO } 1000 \\
\text { GO TO } 1000\end{array}$ \\
\hline
\end{tabular}


4. IUD Revisit

\begin{tabular}{|c|c|c|c|c|}
\hline Q. & QUESTION & \multicolumn{2}{|l|}{ RESPONSE CODE } & SKIP \\
\hline 700 & \multicolumn{3}{|c|}{$\begin{array}{l}\text { READ TO CLIENT: } \\
\text { The current cost of an IUD revisit is I/10 Intis. This is just the cost of the consultation, your total } \\
\text { cost may be greater if other tests recommended by clinic personnel were performed. }\end{array}$} & \\
\hline 701 & Did you pay the price posted above? & $\begin{array}{l}\text { Yes } \\
\text { No }\end{array}$ & & GO TO 704 \\
\hline 702 & How much did you pay? & Amount: & & \\
\hline 703 & $\begin{array}{l}\text { Why did you pay more/less than the posted } \\
\text { price? } \\
\text { DETERMINE IF DIFFERENCE IN PRICE } \\
\text { IS DUE TO PAYING FOR OTHER } \\
\text { SERVICES. IF YES, CONTINUE } \\
\text { INTERVIEW. IF NO, RECORD REASON } \\
\text { AND END INTERVIEW. }\end{array}$ & Reason: & & \\
\hline 704 & \multicolumn{3}{|c|}{$\begin{array}{l}\text { READ TO CLIENT: } \\
\text { I would now like to ask you some questions about your response to potential changes in the price of } \\
\text { this consultation fee. In answering these questions, please bear in mind the following: } \\
\text { 1. Assume that your income will stay the same even if AGENCY prices change. } \\
\text { 2. Alternatives do exist for AGENCY services. }\end{array}$} & \\
\hline 705 & $\begin{array}{l}\text { Suppose that the price of an IUD revisit } \\
\text { increased by I/5 to I/15. Would you come to } \\
\text { AGENCY for your IUD revisit if the price were } \\
\text { I/15? }\end{array}$ & $\begin{array}{l}\text { Yes } \\
\text { No } \\
\text { Don't Know }\end{array}$ & $\begin{array}{l}1 \\
2 \\
99\end{array}$ & $\begin{array}{l}\text { GO TO } 707 \\
\text { GO TO } 707\end{array}$ \\
\hline 706 & $\begin{array}{l}\text { Suppose that the price of an IUD revisit } \\
\text { increased even further, by } I / 10 \text { to } / 20 \text {. Would } \\
\text { you come to AGENCY for your IUD revisit if } \\
\text { the price were } I / 20 \text { ? }\end{array}$ & $\begin{array}{l}\text { Yes } \\
\text { No } \\
\text { Don't Know }\end{array}$ & $\begin{array}{l}1 \\
2 \\
99\end{array}$ & $\begin{array}{l}\text { GO TO } 708 \\
\text { GO TO } 708 \\
\text { GO TO } 708\end{array}$ \\
\hline 707 & $\begin{array}{l}\text { Suppose that the price increase was less than } \\
\text { the previous amount. Suppose the price of an } \\
\text { IUD revisit increased by } I / 2 \text { to } I / 12 \text {. Would you } \\
\text { come to AGENCY for your IUD revisit if the } \\
\text { price were } I / 12 \text { ? }\end{array}$ & $\begin{array}{l}\text { Yes } \\
\text { No } \\
\text { Don't Know }\end{array}$ & $\begin{array}{l}1 \\
2 \\
99\end{array}$ & \\
\hline 708 & $\begin{array}{l}\text { What would be the highest price you would be } \\
\text { willing to pay for an IUD revisit from } \\
\text { AGENCY? }\end{array}$ & Amount & & \\
\hline 709 & $\begin{array}{l}\text { If AGENCY increased the price of an IUD } \\
\text { revisit beyond what you were willing or able to } \\
\text { pay, what would you do? }\end{array}$ & $\begin{array}{l}\text { Go without service } \\
\text { Go somewhere else } \\
\text { I don't know } \\
\text { Other: specify }\end{array}$ & $\begin{array}{l}1 \\
2 \\
99 \\
88\end{array}$ & $\begin{array}{l}\text { GO TO } 1000 \\
\text { GO TO } 710 \\
\text { GO TO } 1000 \\
\text { GO TO } 1000\end{array}$ \\
\hline 710 & $\begin{array}{l}\text { Where would you go? } \\
\text { DO NOT READ CHOICES } \\
\text { CODE ALL MENTIONED }\end{array}$ & $\begin{array}{l}\text { Public Sector } \\
\text { Other NGO } \\
\text { Private Sector } \\
\text { Pharmacy } \\
\text { Other: specify } \\
\text { I don't know }\end{array}$ & $\begin{array}{l}1 \\
2 \\
3 \\
4 \\
88 \\
99\end{array}$ & $\begin{array}{l}\text { GO TO } 1000 \\
\text { GO TO } 1000 \\
\text { GO TO } 1000 \\
\text { GO TO } 1000 \\
\text { GO TO } 1000 \\
\text { GO TO } 1000\end{array}$ \\
\hline
\end{tabular}


5. Pill Purchase

\begin{tabular}{|c|c|c|c|c|}
\hline Q. & QUESTION & \multicolumn{2}{|l|}{ RESPONSE CODE } & SKIP \\
\hline 800 & \multicolumn{3}{|c|}{$\begin{array}{l}\text { READ TO CLIENT: } \\
\text { The current cost of BRAND oral contraceptives is I/3 Intis. This is just the cost of one cycle of pills, } \\
\text { your total cost may be greater if other tests recommended by clinic personnel were performed. }\end{array}$} & \\
\hline 801 & Did you pay the price posted above? & $\begin{array}{l}\text { Yes } \\
\text { No }\end{array}$ & $\begin{array}{l}1 \\
2\end{array}$ & GO TO 804 \\
\hline 802 & How much did you pay? & Amount: & & \\
\hline 803 & $\begin{array}{l}\text { Why did you pay more/less than the posted } \\
\text { price? } \\
\text { DETERMINE IF DIFFERENCE IN PRICE } \\
\text { IS DUE TO PAYING FOR OTHER } \\
\text { SERVICES. IF YES, CONTINUE } \\
\text { INTERVIEW. IF NO, RECORD REASON } \\
\text { AND END INTERVIEW. }\end{array}$ & Reason: & & \\
\hline 804 & \multicolumn{3}{|c|}{$\begin{array}{l}\text { READ TO CLIENT: } \\
\text { I would now like to ask you some questions about your response to potential changes in the price of } \\
\text { this consultation fee. In answering these questions, please bear in mind the following: } \\
\text { 1. Assume that your income will stay the same even if AGENCY prices change. } \\
\text { 2. Alternatives do exist for AGENCY services. }\end{array}$} & \\
\hline 805 & $\begin{array}{l}\text { Suppose that the price of BRAND oral } \\
\text { contraceptives increased by } \mathrm{I} / 2 \text { to } \mathrm{I} / 5 \text {. Would } \\
\text { you purchase your pills from AGENCY if the } \\
\text { price were I/5? }\end{array}$ & $\begin{array}{l}\text { Yes } \\
\text { No } \\
\text { Don't Know }\end{array}$ & $\begin{array}{l}1 \\
2 \\
99\end{array}$ & $\begin{array}{l}\text { GO TO } 807 \\
\text { GO TO } 807\end{array}$ \\
\hline 806 & $\begin{array}{l}\text { Suppose that the price of BRAND oral } \\
\text { contraceptives increased even further, by I/3 to } \\
\text { I/6. Would you purchase your pills from } \\
\text { AGENCY if the price were } I / 6 \text { ? }\end{array}$ & $\begin{array}{l}\text { Yes } \\
\text { No } \\
\text { Don't Know }\end{array}$ & $\begin{array}{l}1 \\
2 \\
99\end{array}$ & $\begin{array}{l}\text { GO TO } 808 \\
\text { GO TO } 808 \\
\text { GO TO } 808\end{array}$ \\
\hline 807 & $\begin{array}{l}\text { Suppose that the price increase was less than } \\
\text { the previous amount. Suppose the price of } \\
\text { BRAND oral contraceptives increased by I/ } 1 \text { to } \\
\text { I/4. Would you purchase your pills from } \\
\text { AGENCY if the price were I/4? }\end{array}$ & $\begin{array}{l}\text { Yes } \\
\text { No } \\
\text { Don't Know }\end{array}$ & $\begin{array}{l}1 \\
2 \\
99\end{array}$ & \\
\hline 808 & $\begin{array}{l}\text { What would be the highest price you would be } \\
\text { willing to pay for BRAND oral contraceptives } \\
\text { from AGENCY? }\end{array}$ & Amount & & \\
\hline 809 & $\begin{array}{l}\text { If AGENCY increased the price of BRAND } \\
\text { oral contraceptives beyond what you were } \\
\text { willing or able to pay, what would you do? }\end{array}$ & $\begin{array}{l}\text { Not use a contraceptive method } \\
\text { Go somewhere else } \\
\text { Switch to a cheaper method } \\
\quad \text { Specify: } \\
\text { Other: specify } \\
\text { I don't know }\end{array}$ & $\begin{array}{l}1 \\
2 \\
3 \\
88 \\
99 \\
\end{array}$ & $\begin{array}{l}\text { GO TO } 1000 \\
\text { GO TO } 810 \\
\text { GO TO } 1000 \\
\text { GO TO } 1000 \\
\text { GO TO } 1000 \\
\text { GO TO } 1000\end{array}$ \\
\hline 810 & $\begin{array}{l}\text { Where would you go? } \\
\text { DO NOT READ CHOICES } \\
\text { CODE ALL MENTIONED }\end{array}$ & $\begin{array}{l}\text { Public Sector } \\
\text { Other NGO } \\
\text { Private Sector } \\
\text { Pharmacy } \\
\text { Other: specify } \\
\text { I don't know }\end{array}$ & $\begin{array}{l}1 \\
2 \\
3 \\
4 \\
88 \\
99 \\
\end{array}$ & $\begin{array}{l}\text { GO TO } 1000 \\
\text { GO TO } 1000 \\
\text { GO TO } 1000 \\
\text { GO TO } 1000 \\
\text { GO TO } 1000 \\
\text { GO TO } 1000\end{array}$ \\
\hline
\end{tabular}


6. Prenatal Care

\begin{tabular}{|c|c|c|c|c|}
\hline Q. & QUESTION & \multicolumn{2}{|l|}{ RESPONSE CODE } & SKIP \\
\hline 900 & \multicolumn{3}{|c|}{$\begin{array}{l}\text { READ TO CLIENT: } \\
\text { The current cost of prenatal care is } \mathrm{I} / 15 \text { Intis. This is just the cost of the consultation, your total cost } \\
\text { may be greater if other tests recommended by clinic personnel were performed. }\end{array}$} & \\
\hline 901 & Did you pay the price posted above? & $\begin{array}{l}\text { Yes } \\
\text { No }\end{array}$ & $\begin{array}{l}1 \\
2\end{array}$ & GO TO 904 \\
\hline 902 & How much did you pay? & Amount: & & \\
\hline 903 & $\begin{array}{l}\text { Why did you pay more/less than the posted } \\
\text { price? } \\
\text { DETERMINE IF DIFFERENCE IN PRICE } \\
\text { IS DUE TO PAYING FOR OTHER } \\
\text { SERVICES. IF YES, CONTINUE } \\
\text { INTERVIEW. IF NO, RECORD REASON } \\
\text { AND END INTERVIEW. }\end{array}$ & Reason: & & \\
\hline 904 & \multicolumn{3}{|c|}{$\begin{array}{l}\text { READ TO CLIENT: } \\
\text { I would now like to ask you some questions about your response to potential changes in the price of } \\
\text { this consultation fee. In answering these questions, please bear in mind the following: } \\
\text { 1. Assume that your income will stay the same even if AGENCY prices change. } \\
\text { 2. Alternatives do exist for AGENCY services. }\end{array}$} & \\
\hline 905 & $\begin{array}{l}\text { Suppose that the price of prenatal care } \\
\text { increased by } I / 5 \text { to } I / 20 \text {. Would you come to } \\
\text { AGENCY for your prenatal care if the price } \\
\text { were } I / 20 \text { ? }\end{array}$ & $\begin{array}{l}\text { Yes } \\
\text { No } \\
\text { Don't Know }\end{array}$ & $\begin{array}{l}1 \\
2 \\
99\end{array}$ & $\begin{array}{l}\text { GO TO } 907 \\
\text { GO TO } 907\end{array}$ \\
\hline 906 & $\begin{array}{l}\text { Suppose that the price of prenatal care } \\
\text { increased even further, by } I / 10 \text { to } I / 25 \text {. Would } \\
\text { you come to AGENCY for your prenatal care if } \\
\text { the price were } I / 25 \text { ? }\end{array}$ & $\begin{array}{l}\text { Yes } \\
\text { No } \\
\text { Don't Know }\end{array}$ & $\begin{array}{l}1 \\
2 \\
99\end{array}$ & $\begin{array}{l}\text { GO TO } 908 \\
\text { GO TO } 908 \\
\text { GO TO } 908\end{array}$ \\
\hline 907 & $\begin{array}{l}\text { Suppose that the price increase was less than } \\
\text { the previous amount. Suppose the price of } \\
\text { prenatal care increased by } I / 2 \text { to } I / 17 \text {. Would } \\
\text { you come to AGENCY for your prenatal care if } \\
\text { the price were } I / 17 \text { ? }\end{array}$ & $\begin{array}{l}\text { Yes } \\
\text { No } \\
\text { Don't Know }\end{array}$ & $\begin{array}{l}1 \\
2 \\
99\end{array}$ & \\
\hline 908 & $\begin{array}{l}\text { What would be the highest price you would be } \\
\text { willing to pay for prenatal care from } \\
\text { AGENCY? }\end{array}$ & Amount & & \\
\hline 909 & $\begin{array}{l}\text { If AGENCY increased the price of prenatal } \\
\text { care beyond what you were willing or able to } \\
\text { pay, what would you do? }\end{array}$ & $\begin{array}{l}\text { Go without service } \\
\text { Go somewhere else } \\
\text { I don't know } \\
\text { Other: specify }\end{array}$ & $\begin{array}{l}1 \\
2 \\
99 \\
88\end{array}$ & $\begin{array}{l}\text { GO TO } 1000 \\
\text { GO TO } 910 \\
\text { GO TO } 1000 \\
\text { GO TO } 1000\end{array}$ \\
\hline 910 & $\begin{array}{l}\text { Where would you go? } \\
\text { DO NOT READ CHOICES } \\
\text { CODE ALL MENTIONED }\end{array}$ & $\begin{array}{l}\text { Public Sector } \\
\text { Other NGO } \\
\text { Private Sector } \\
\text { Pharmacy } \\
\text { Other: specify } \\
\text { I don't know }\end{array}$ & $\begin{array}{l}1 \\
2 \\
3 \\
4 \\
88 \\
99\end{array}$ & $\begin{array}{l}\text { GO TO } 1000 \\
\text { GO TO } 1000 \\
\text { GO TO } 1000 \\
\text { GO TO } 1000 \\
\text { GO TO } 1000 \\
\text { GO TO } 1000\end{array}$ \\
\hline
\end{tabular}




\section{(THE FOLLOWING QUESTIONS ARE ASKED OF ALL INTERVIEWEES WHO COMPLETED AN EARLIER WTP SEQUENCE)}

\section{E. WTP Questions: Potential Users}

1. Female Sterilization

\begin{tabular}{|c|c|c|c|c|}
\hline Q. & QUESTION & RESPONSE CODE & & SKIP \\
\hline 1000 & $\begin{array}{l}\text { Have you heard of the operation to have no } \\
\text { more children (VSC)? }\end{array}$ & $\begin{array}{l}\text { Yes } \\
\text { No } \\
\text { Don't Know }\end{array}$ & $\begin{array}{l}1 \\
2 \\
99\end{array}$ & $\begin{array}{l}\text { GO TO } 1100 \\
\text { GO TO } 1100\end{array}$ \\
\hline 1001 & $\begin{array}{l}\text { Are you interested in having this operation if } \\
\text { the next two years? }\end{array}$ & $\begin{array}{l}\text { Yes } \\
\text { No } \\
\text { Already Had It } \\
\text { Don't Know }\end{array}$ & $\begin{array}{l}1 \\
2 \\
3 \\
99 \\
\end{array}$ & $\begin{array}{l}\text { GO TO } 1100 \\
\text { GO TO } 1100 \\
\text { GO TO } 1100\end{array}$ \\
\hline 1002 & \multicolumn{3}{|c|}{$\begin{array}{l}\text { READ TO CLIENT: } \\
\text { I would now like to ask you some questions about the possible price of this operation. In answering } \\
\text { these questions, please bear in mind the following: } \\
\text { 1. Assume that your income will stay the same even if AGENCY prices change. } \\
\text { 2. Alternatives do exist for AGENCY services. }\end{array}$} & \\
\hline 1003 & $\begin{array}{l}\text { If the price of this operation were } / / 200 \text {, would } \\
\text { you purchase this service from AGENCY? }\end{array}$ & $\begin{array}{l}\text { Yes } \\
\text { No } \\
\text { Don't Know }\end{array}$ & $\begin{array}{l}1 \\
2 \\
99 \\
\end{array}$ & $\begin{array}{l}\text { GO TO } 1005 \\
\text { GO TO } 1005\end{array}$ \\
\hline 1004 & $\begin{array}{l}\text { If the price of this operation were } I / 300 \text {, would } \\
\text { you purchase this service from AGENCY? }\end{array}$ & $\begin{array}{l}\text { Yes } \\
\text { No } \\
\text { Don't Know }\end{array}$ & $\begin{array}{l}1 \\
2 \\
99 \\
\end{array}$ & $\begin{array}{l}\text { GO TO } 1006 \\
\text { GO TO } 1006 \\
\text { GO TO } 1006 \\
\end{array}$ \\
\hline 1005 & $\begin{array}{l}\text { If the price of this operation were } \mathrm{I} / 100, \text { would } \\
\text { you purchase this service from AGENCY? }\end{array}$ & $\begin{array}{l}\text { Yes } \\
\text { No } \\
\text { Don't Know }\end{array}$ & $\begin{array}{l}1 \\
2 \\
99\end{array}$ & \\
\hline 1006 & $\begin{array}{l}\text { What would be the highest price you would be } \\
\text { willing to pay for this operation from } \\
\text { AGENCY? }\end{array}$ & Amount & & \\
\hline 1007 & $\begin{array}{l}\text { If you were interested in having this operation } \\
\text { but were unable to pay AGENCY price, what } \\
\text { would you do? }\end{array}$ & $\begin{array}{l}\text { Go without service } \\
\text { Go somewhere else for this service } \\
\text { Other: specify } \\
\text { I don't know }\end{array}$ & $\begin{array}{l}1 \\
2 \\
88 \\
99\end{array}$ & $\begin{array}{l}\text { GO TO } 1008 \\
\text { GO TO } 1009 \\
\text { GO TO } 1100 \\
\text { GO TO } 1100\end{array}$ \\
\hline 1008 & $\begin{array}{l}\text { You said you would not have this operation if } \\
\text { you were unable to pay AGENCY price. Would } \\
\text { you use another contraceptive method? }\end{array}$ & $\begin{array}{l}\text { Yes: specify } \\
\text { No } \\
\text { I don't know }\end{array}$ & $\begin{array}{l}1 \\
2 \\
99\end{array}$ & $\begin{array}{l}\text { GO TO } 1100 \\
\text { GO TO } 1100 \\
\text { GO TO } 1100\end{array}$ \\
\hline 1009 & $\begin{array}{l}\text { Where would you go? } \\
\text { DO NOT READ CHOICES } \\
\text { CODE ALL MENTIONED }\end{array}$ & $\begin{array}{l}\text { Public Sector } \\
\text { Other NGO } \\
\text { Private Sector } \\
\text { Other: specify } \\
\text { I don't know }\end{array}$ & \begin{tabular}{l|}
1 \\
2 \\
3 \\
88 \\
99 \\
\end{tabular} & \\
\hline
\end{tabular}

\section{F. WTP for Amenities and Quality Improvements}

1. WTP for Reduced Waiting Time

\begin{tabular}{|c|c|c|c|c|}
\hline $\mathbf{Q}$. & QUESTION & RESPONSE CODE & & SKIP \\
\hline 1100 & $\begin{array}{l}\text { How long did you have to wait before you were } \\
\text { seen by clinic staff? }\end{array}$ & Time in Minutes & & \\
\hline 1101 & $\begin{array}{l}\text { Do you consider this wait to be excessive, } \\
\text { reasonable, or short? }\end{array}$ & $\begin{array}{l}\text { Excessive } \\
\text { Reasonable } \\
\text { Short }\end{array}$ & $\begin{array}{l}1 \\
2 \\
3\end{array}$ & \\
\hline 1102 & $\begin{array}{l}\text { Suppose we could cut your waiting time in half } \\
\text { but your consultation would cost } 3 \text { Intis more, } \\
\text { or AMOUNT PAID+3. Would you be willing } \\
\text { to pay for this improvement? }\end{array}$ & $\begin{array}{l}\text { Yes } \\
\text { No } \\
\text { Don't know }\end{array}$ & $\begin{array}{c}1 \\
2 \\
99\end{array}$ & $\begin{array}{l}\text { GO TO } 1104 \\
\text { GO TO } 1104\end{array}$ \\
\hline
\end{tabular}




\begin{tabular}{|c|c|c|c|c|}
\hline 1103 & $\begin{array}{l}\text { Suppose we could cut your waiting time in half } \\
\text { but your consultation would cost } 6 \text { Intis more, } \\
\text { or AMOUNT PAID+6. Would you be willing } \\
\text { to pay for this improvement? }\end{array}$ & $\begin{array}{l}\text { Yes } \\
\text { No } \\
\text { Don't know }\end{array}$ & $\begin{array}{c}1 \\
2 \\
99\end{array}$ & $\begin{array}{l}\text { GO TO } 1105 \\
\text { GO TO } 1105 \\
\text { GO TO } 1105\end{array}$ \\
\hline 1104 & $\begin{array}{l}\text { Suppose we could cut your waiting time in half } \\
\text { but your consultation would cost one Inti more, } \\
\text { or AMOUNT PAID+1. Would you be willing } \\
\text { to pay for this improvement? }\end{array}$ & $\begin{array}{l}\text { Yes } \\
\text { No } \\
\text { Don't know }\end{array}$ & $\begin{array}{c}1 \\
2 \\
99\end{array}$ & \\
\hline 1105 & $\begin{array}{l}\text { What is the most you would be willing to pay } \\
\text { for your consultation if this improvement were } \\
\text { made? }\end{array}$ & Amount & & \\
\hline
\end{tabular}

2. WTP for Counseling

\begin{tabular}{|c|c|c|c|c|}
\hline $\mathbf{Q}$. & QUESTION & RESPONSE CODE & & SKIP \\
\hline 1200 & $\begin{array}{l}\text { How much time did your provider spend with } \\
\text { you explaining procedures and counseling you } \\
\text { on your reproductive health problems? }\end{array}$ & Time in Minutes & & \\
\hline 1201 & $\begin{array}{l}\text { Do you consider the amount of time the } \\
\text { provider spent with you to be excessive, } \\
\text { reasonable, or short? }\end{array}$ & $\begin{array}{l}\text { Excessive } \\
\text { Reasonable } \\
\text { Short }\end{array}$ & $\begin{array}{l}1 \\
2 \\
3\end{array}$ & GO TO 1300 \\
\hline 1202 & $\begin{array}{l}\text { Suppose we could increase counseling time you } \\
\text { could spend with your provider by an additional } \\
10 \text { minutes but your consultation would cost } \\
\text { three Intis more, or AMOUNT PAID+3. } \\
\text { Would you be willing to pay for this } \\
\text { improvement? }\end{array}$ & $\begin{array}{l}\text { Yes } \\
\text { No } \\
\text { Don't know }\end{array}$ & $\begin{array}{c}1 \\
2 \\
99\end{array}$ & $\begin{array}{l}\text { GO TO } 1204 \\
\text { GO TO } 1204\end{array}$ \\
\hline 1203 & $\begin{array}{l}\text { Suppose we could increase counseling time you } \\
\text { could spend with your provider by an additional } \\
10 \text { minutes but your consultation would cost six } \\
\text { Intis more, or AMOUNT PAID+6. Would you } \\
\text { be willing to pay for this improvement? }\end{array}$ & $\begin{array}{l}\text { Yes } \\
\text { No } \\
\text { Don't know }\end{array}$ & $\begin{array}{c}1 \\
2 \\
99\end{array}$ & $\begin{array}{l}\text { GO TO } 1205 \\
\text { GO TO } 1205 \\
\text { GO TO } 1205\end{array}$ \\
\hline 1204 & $\begin{array}{l}\text { Suppose we could increase counseling time you } \\
\text { could spend with your provider by an additional } \\
10 \text { minutes but your consultation would cost } \\
\text { one Inti more, or AMOUNT PAID+1. Would } \\
\text { you be willing to pay for this improvement? }\end{array}$ & $\begin{array}{l}\text { Yes } \\
\text { No } \\
\text { Don't know }\end{array}$ & $\begin{array}{c}1 \\
2 \\
99\end{array}$ & \\
\hline 1205 & $\begin{array}{l}\text { What is the most you would be willing to pay } \\
\text { for your consultation if this improvement were } \\
\text { made? }\end{array}$ & Amount & & \\
\hline
\end{tabular}

3. WTP for Clinic Improvements

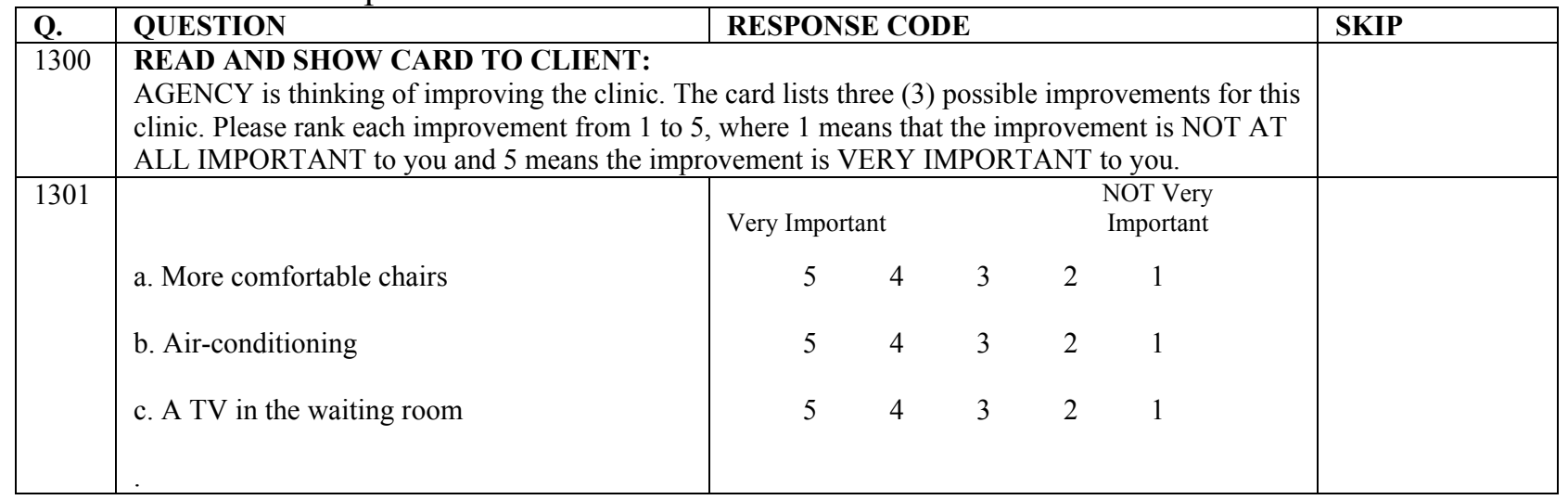




\begin{tabular}{|l|l|l|}
\hline 1302 & $\begin{array}{l}\text { NOTE: IF RESPONDENT HAS TWO OR MORE SELECTIONS WITH THE SAME HIGHEST } \\
\text { SCORE, ASK HER WHICH AMENITY IS MOST IMPORTANT TO HER; IF SHE HAD TO } \\
\text { CHOOSE, WHICH WOULD SHE CHOOSE. }\end{array}$ & \\
& $\begin{aligned} \text { If "a" is most important GO TO } 1303 . \\
\text { If "b" is most important GO TO } 1307 . \\
\text { If "c" is most important GO TO } 1311 .\end{aligned}$ & \\
\hline
\end{tabular}

\begin{tabular}{|c|c|c|c|c|}
\hline 1303 & $\begin{array}{l}\text { You ranked more comfortable chairs as the } \\
\text { most important improvement. Would you be } \\
\text { willing to pay two Intis more, or AMOUNT } \\
\text { PAID+2, for your next visit if the clinic added } \\
\text { this amenity? }\end{array}$ & $\begin{array}{l}\text { Yes } \\
\text { No } \\
\text { Don't know }\end{array}$ & $\begin{array}{c}1 \\
2 \\
99\end{array}$ & $\begin{array}{l}\text { GO TO } 1305 \\
\text { GO TO } 1305\end{array}$ \\
\hline 1304 & $\begin{array}{l}\text { Would you be willing to pay three Intis more, } \\
\text { or AMOUNT PAID+3, for your next visit if } \\
\text { the clinic added this amenity? }\end{array}$ & $\begin{array}{l}\text { Yes } \\
\text { No } \\
\text { Don't know }\end{array}$ & $\begin{array}{c}1 \\
2 \\
99\end{array}$ & $\begin{array}{l}\text { GO TO } 1306 \\
\text { GO TO } 1306 \\
\text { GO TO } 1306\end{array}$ \\
\hline 1305 & $\begin{array}{l}\text { Would you be willing to pay one more Inti, or } \\
\text { AMOUNT PAID+1, for your next visit if the } \\
\text { clinic added this amenity? }\end{array}$ & $\begin{array}{l}\text { Yes } \\
\text { No } \\
\text { Don't know }\end{array}$ & $\begin{array}{c}1 \\
2 \\
99 \\
\end{array}$ & \\
\hline 1306 & $\begin{array}{l}\text { What would be the most you would be willing } \\
\text { to pay for your consultation if this improvement } \\
\text { were made? }\end{array}$ & Amount & & \\
\hline 1307 & $\begin{array}{l}\text { You ranked air-conditioning as the most } \\
\text { important improvement., Would you be willing } \\
\text { to pay two Intis more, or AMOUNT PAID+2, } \\
\text { for your next visit if the clinic added this } \\
\text { amenity? }\end{array}$ & $\begin{array}{l}\text { Yes } \\
\text { No } \\
\text { Don't know }\end{array}$ & $\begin{array}{c}1 \\
2 \\
99\end{array}$ & $\begin{array}{l}\text { GO TO } 1309 \\
\text { GO TO } 1309\end{array}$ \\
\hline 1308 & $\begin{array}{l}\text { Would you be willing to pay three Intis more, } \\
\text { or AMOUNT PAID }+3 \text {, for your next visit if } \\
\text { the clinic added this amenity? }\end{array}$ & $\begin{array}{l}\text { Yes } \\
\text { No } \\
\text { Don't know }\end{array}$ & $\begin{array}{c}1 \\
2 \\
99 \\
\end{array}$ & $\begin{array}{l}\text { GO TO } 1310 \\
\text { GO TO } 1310 \\
\text { GO TO } 1310\end{array}$ \\
\hline 1309 & $\begin{array}{l}\text { Would you be willing to pay one more Inti, or } \\
\text { AMOUNT PAID+1, for your next visit if the } \\
\text { clinic added this amenity? }\end{array}$ & $\begin{array}{l}\text { Yes } \\
\text { No } \\
\text { Don't know }\end{array}$ & $\begin{array}{c}1 \\
2 \\
99 \\
\end{array}$ & \\
\hline 1310 & $\begin{array}{l}\text { What would be the most you would be willing } \\
\text { to pay for your consultation if this improvement } \\
\text { were made? }\end{array}$ & Amount & & \\
\hline 1311 & $\begin{array}{l}\text { You ranked TV as the most important } \\
\text { improvement. Would you be willing to pay two } \\
\text { Intis more, or AMOUNT PAID+2, for your } \\
\text { next visit if the clinic added this amenity? }\end{array}$ & $\begin{array}{l}\text { Yes } \\
\text { No } \\
\text { Don't know }\end{array}$ & $\begin{array}{c}1 \\
2 \\
99\end{array}$ & $\begin{array}{l}\text { GO TO } 1313 \\
\text { GO TO } 1313\end{array}$ \\
\hline 1312 & $\begin{array}{l}\text { Would you be willing to pay three Intis more, } \\
\text { or AMOUNT PAID+3, for your next visit if } \\
\text { the clinic added this amenity? }\end{array}$ & $\begin{array}{l}\text { Yes } \\
\text { No } \\
\text { Don't know }\end{array}$ & $\begin{array}{c}1 \\
2 \\
99 \\
\end{array}$ & $\begin{array}{l}\text { GO TO } 1314 \\
\text { GO TO } 1314 \\
\text { GO TO } 1314 \\
\end{array}$ \\
\hline 1313 & $\begin{array}{l}\text { Would you be willing to pay one more Inti, or } \\
\text { AMOUNT PAID+1, for your next visit if the } \\
\text { clinic added this amenity? }\end{array}$ & $\begin{array}{l}\text { Yes } \\
\text { No } \\
\text { Don't know }\end{array}$ & $\begin{array}{c}1 \\
2 \\
99\end{array}$ & \\
\hline 1314 & $\begin{array}{l}\text { What would be the most you would be willing } \\
\text { to pay for your consultation if this improvement } \\
\text { were made? }\end{array}$ & Amount & & \\
\hline
\end{tabular}

\section{\begin{tabular}{|l|l} 
END & END INTERVIEW AND THANK RESPONDENT FOR HER TIME.
\end{tabular}}




\section{Condoms \\ Willingness to Pay \\ Model Questionnaire for Married Men \\ or Sexually Active Men, Ages 15-45 years \\ (Based on a Futures Group/INFO-STAT Study in Mali, 1999) \\ HOUSEHOLD SURVEY FOR CONDOM USERS AND POTENTIAL USERS}

Hello! My name is . I work for a research agency called . I would like to ask you some questions on condoms, a product that can be used to stop or prevent pregnancy, sexually transmitted infections, and AIDS. The interview is not required, but I would be very grateful if you would answer a few questions. Everything you say will be confidential, and no one will know how you personally answered the questions I am going to ask.

Participation Yes-- $\rightarrow$ Continue

No-- $\rightarrow$ End Interview

Questionnaire Number:

Date:

Name of interviewer:
Region:
1. Bamako
2. Sikasso
3. Mopti

Zone:

1. Urban

2. Rural

Town/Village:

Neighborhood:

Name of respondent:

Note: Questions based on condoms sold in packages of 3 


\begin{tabular}{|c|c|c|}
\hline QUESTION & RESPONSE CODE & SKIP \\
\hline 1. How old are you? & $\frac{\mid}{(\text { minim. }}=15$ years, $\operatorname{maxim}=45$ years $)$ & \\
\hline 2. Marital status/Sexual activity & $\begin{array}{l}\text { 1. Married (Marriage } \\
\text { consummate) } \\
\text { 2. Living with someone } \\
\text { 3. Not in a relationship, } \\
\text { sexually active } \\
\text { 4. Not in a relationship, not } \\
\text { sexually active }\end{array}$ & \\
\hline $\begin{array}{l}\text { 3. How many living children do } \\
\text { you have? }\end{array}$ & L_ا & \\
\hline 4. Have you attended school? & $\begin{array}{ll}\text { 1. } & \text { Yes } \\
\text { 2. } & \text { No }\end{array}$ & $\rightarrow$ Go to question 6 \\
\hline $\begin{array}{l}\text { 5. What is the level that you } \\
\text { reached? }\end{array}$ & $\begin{array}{ll}\text { 1. } & \text { Primary } \\
\text { 2. } & \text { Secondary } \\
\text { 3. } & \text { High school } \\
\text { 4. } & \text { Higher education }\end{array}$ & \\
\hline 6. What is your profession? & $\begin{array}{ll}\text { 1. } & \text { Student } \\
\text { 2. } & \text { Unemployed } \\
\text { 3. } & \text { Office worker } \\
\text { 4. } & \text { Shop-keeper } \\
\text { 5. } & \text { Self-employed } \\
\text { 6. } & \text { Farmer } \\
\text { 7. } & \text { Herder/Breeder } \\
\text { 8. } & \text { Fisherman } \\
\text { 88. } & \text { Other, } \\
\end{array}$ & \\
\hline 7. Does your household have: & $\begin{array}{l}\mid \text { - Television } \\
\text { - Refrigerator } \\
\text { - Car } \\
\text { - Motorcycle } \\
\text { - Radio } \\
\text { - Bike } \\
\text { - Horse-drawn cart } \\
\text { - Plow } \\
\text { - Oxen } \\
\text { Codes: } 1=\text { Yes } \quad 2=\text { No }\end{array}$ & \\
\hline
\end{tabular}


Interviewer: Explain to respondent that you will now ask him a series of questions about his condom use.

\begin{tabular}{|c|c|c|}
\hline QUESTION & RESPONSE CODE & SKIP \\
\hline $\begin{array}{l}\text { 8. Have you ever heard of the } \\
\text { condom, a birth control and disease } \\
\text { prevention method that a man uses? }\end{array}$ & $\begin{array}{ll}\text { 1. } & \text { Yes } \\
\text { 2. } & \text { No }\end{array}$ & $\rightarrow$ Terminate interview \\
\hline 9. Have you ever used a condom? & $\begin{array}{ll}\text { 1. } & \text { Yes } \\
\text { 2. } & \text { No }\end{array}$ & $\rightarrow$ Go to question 27 \\
\hline $\begin{array}{l}\text { 10. Have you used a condom in the } \\
\text { last } 3 \text { months? }\end{array}$ & $\begin{array}{ll}\text { 1. } & \text { Yes } \\
\text { 2. } & \text { No }\end{array}$ & $\rightarrow$ Go to question 23 \\
\hline $\begin{array}{l}\text { 11. The last time that you used a } \\
\text { condom what brand was it? (show } \\
\text { packaging if necessary, only one } \\
\text { response) }\end{array}$ & $\begin{array}{l}\text { 1. Condom Protector } \\
\text { 88. Other than } \\
\text { Protector, } \\
\text { 99. I don't remember at all }\end{array}$ & \\
\hline $\begin{array}{l}\text { 12. What other brand (s) have you } \\
\text { used in the last three months? } \\
\text { (several responses possible) }\end{array}$ & $\begin{array}{l}\text { 1. Nothing else } \\
\text { 88. Other, } \\
\text { 99. Don't remember }\end{array}$ & \\
\hline $\begin{array}{l}\text { 13. The last time you used a } \\
\text { condom, where did you get it? }\end{array}$ & $\begin{array}{ll}\text { 1. } & \text { Store } \\
\text { 2. } & \text { Pharmacy } \\
\text { 3. } & \text { Community health center } \\
& (\mathrm{CSCOM}) \\
\text { 4. Other health center } \\
\text { 5. }\end{array}$ & \\
\hline $\begin{array}{l}\text { 14. The last time you bought } \\
\text { condoms how many packages of } 3 \\
\text { did you buy? }\end{array}$ & & \\
\hline $\begin{array}{l}\text { 15. The last time you bought } \\
\text { condoms, how much did you pay } \\
\text { per } 3 \text { pack? } \\
\text { Interviewer: if the amount in } \\
\text { question } 14 \text { is more than } 3 \text {, then } \\
\text { help respondent figure out } \\
\text { amount paid per } 3 \text {-pack by } \\
\text { dividing total paid by number of } \\
\text { packages purchased. }\end{array}$ & $\begin{array}{l}\text { F CFA } \\
\text { Code } 0 \text { F= nothing/ free } \\
\text { Code 99= I don't remember }\end{array}$ & \\
\hline
\end{tabular}




\begin{tabular}{|c|c|c|}
\hline QUESTION & RESPONSE CODE & SKIP \\
\hline $\begin{array}{l}\text { 16. You have said that you last } \\
\text { bought a pack of } 3 \text { condoms } \\
\text { for (cite price in question } \\
\text { 15). If the price increased to } \\
\text { (amount paid }+50 \mathrm{~F}) \text {, would you } \\
\text { continue to buy these condoms? }\end{array}$ & $\begin{array}{ll}\text { 1. } & \text { Yes } \\
\text { 2. } & \text { No }\end{array}$ & $\rightarrow$ Go to question 18 \\
\hline $\begin{array}{l}\text { 17. If the price increased to (amount } \\
\text { paid }+100 \mathrm{~F} \text { ) would you continue to } \\
\text { buy these condoms? }\end{array}$ & $\begin{array}{ll}\text { 1. } & \text { Yes } \\
\text { 2. } & \text { No }\end{array}$ & $\begin{array}{l}\rightarrow \text { Go to question } 19 \\
\rightarrow \text { Go to question } 19\end{array}$ \\
\hline $\begin{array}{l}\text { 18. If the price increased to (amount } \\
\text { paid }+25 \mathrm{~F} \text { ), would you continue to } \\
\text { buy these condoms? }\end{array}$ & $\begin{array}{ll}\text { 1. } & \text { Yes } \\
\text { 2. } & \text { No }\end{array}$ & \\
\hline $\begin{array}{l}\text { 19. What is the maximum price you } \\
\text { would be willing to pay for a pack } \\
\text { of } 3 \text { condoms? }\end{array}$ & F CFA & \\
\hline $\begin{array}{l}\text { 20. If the price of condoms at } \\
\text { (cite place from questions } \\
\text { 13) exceeds what you would be } \\
\text { willing or able to pay, what would } \\
\text { you do? (cite the responses) }\end{array}$ & $\begin{array}{l}\text { 1. Look for a cheaper brand at } \\
\text { the same place } \\
\text { 2. Look for the same brand at a } \\
\text { cheaper location } \\
\text { 3. Look for a cheaper brand and } \\
\text { a cheaper place } \\
\text { 4. Stop using them } \\
\text { 88. Other, }\end{array}$ & \\
\hline $\begin{array}{l}\text { 21. What is the primary reason that } \\
\text { you use condoms? }\end{array}$ & $\begin{array}{ll}\text { 1. } & \text { Prevent pregnancy } \\
\text { 2. } & \text { Protect against } \\
& \text { STI/HIV/AIDS } \\
\text { 3. } & \text { Both }\end{array}$ & \\
\hline $\begin{array}{l}\text { 22. With whom did you use } \\
\text { condoms the last time you used one? }\end{array}$ & $\begin{array}{l}\text { 1. My wife } \\
\text { 2. A regular partner who is not } \\
\text { my wife } \\
\text { 3. An occasional partner } \\
\text { 88. Other, } \\
\text { 99. No response }\end{array}$ & $\rightarrow$ Terminate interview \\
\hline $\begin{array}{l}\text { 23. How long ago was the last time } \\
\text { you used a condom? }\end{array}$ & $\begin{array}{ll}\text { 1. } & 4-6 \text { months } \\
\text { 2. } & 7-12 \text { months } \\
\text { 3. } & \text { More that } 1 \text { year } \\
\text { 99. I don't remember }\end{array}$ & $\begin{array}{l}\rightarrow \text { Go to question } 27 \\
\rightarrow \text { Go to question } 27\end{array}$ \\
\hline $\begin{array}{l}\text { 24. For what reason did you use } \\
\text { condoms in the past? }\end{array}$ & $\begin{array}{ll}\text { 1. } & \text { Prevent pregnancy } \\
\text { 2. } & \text { Protect against } \\
& \text { STI/HIV/AIDS } \\
\text { 3. } & \text { Both }\end{array}$ & \\
\hline
\end{tabular}




\begin{tabular}{|c|c|c|}
\hline QUESTION & RESPONSE CODE & SKIP \\
\hline $\begin{array}{l}\text { 25. With whom did you use } \\
\text { condoms the last time? }\end{array}$ & $\begin{array}{l}\text { 1. My wife } \\
\text { 2. A regular partner who is not } \\
\text { my wife } \\
\text { 3. An occasional partner } \\
\text { 88. Other, } \\
\text { 99. No response }\end{array}$ & \\
\hline $\begin{array}{l}\text { 26. Where do you normally buy } \\
\text { condoms? }\end{array}$ & $\begin{array}{ll}\text { 1. } & \text { Store } \\
\text { 2. } & \text { Pharmacy } \\
\text { 3. } & \text { Community health center } \\
& (\mathrm{CSCOM}) \\
\text { 4. } & \text { Other health center } \\
\text { 5. } & \text { Community-based } \\
\text { distribution agent } \\
\text { 88. } \\
\text { 9thers, } \\
\text { 99. Don't know/ Don't } \\
\text { remember }\end{array}$ & \\
\hline $\begin{array}{l}\text { 27. For what reason did you stop } \\
\text { using condoms? }\end{array}$ & $\begin{array}{l}\text { 1. No means/too expensive } \\
\text { 2. Wanted children } \\
\text { 3. No longer like to use, reason } \\
\text { 4. Not easy to obtain } \\
\text { 5. Not sexually active } \\
\text { 88. Other, specifically }\end{array}$ & \\
\hline $\begin{array}{l}28 . \text { Would you use a condom in the } \\
\text { future? }\end{array}$ & $\begin{array}{ll}\text { 1. } & \text { Yes } \\
\text { 2. } & \text { No } \\
\text { 99. } & \text { Don’t know }\end{array}$ & $\begin{array}{l}\rightarrow \text { Go to question } 34 \\
\rightarrow \text { Terminate interview }\end{array}$ \\
\hline $\begin{array}{l}\text { 29. Would you buy a packet of } 3 \\
\text { condoms for } 100 \mathrm{~F} \text { ? }\end{array}$ & $\begin{array}{ll}\text { 1. } & \text { Yes } \\
\text { 2. } & \text { No }\end{array}$ & $\rightarrow$ Go to question 31 \\
\hline $\begin{array}{l}\text { 30. Would you buy a packet of } 3 \\
\text { condoms for } 150 \mathrm{~F} \text { ? }\end{array}$ & $\begin{array}{ll}\text { 1. } & \text { Yes } \\
\text { 2. } & \text { No }\end{array}$ & $\begin{array}{l}\rightarrow \text { Go to question } 32 \\
\rightarrow \text { Go to question } 32\end{array}$ \\
\hline $\begin{array}{l}\text { 31. Would you buy a packet of } 3 \\
\text { condoms for } 75 \mathrm{~F} \text { ? }\end{array}$ & $\begin{array}{ll}\text { 1. } & \text { Yes } \\
\text { 2. } & \text { No }\end{array}$ & $\begin{array}{l}\rightarrow \text { Go to question } 32 \\
\rightarrow \text { Go to question } 32\end{array}$ \\
\hline $\begin{array}{l}\text { 32. What is the maximum price that } \\
\text { you would be willing to pay for a } \\
\text { packet of } 3 \text { condoms? }\end{array}$ & $\begin{array}{l}\text { F CFA } \\
\mathbf{0}=\mathbf{\text { No purchase }}\end{array}$ & \\
\hline $\begin{array}{l}\text { 33. What is the primary reason that } \\
\text { you would use condoms in the } \\
\text { future? }\end{array}$ & $\begin{array}{ll}\text { 1. } & \text { Prevent pregnancy } \\
\text { 2. } & \text { Protect against } \\
\text { STI/HIV/AIDS } \\
\text { 3. } & \text { Both }\end{array}$ & \\
\hline
\end{tabular}




\begin{tabular}{|l|l|l|}
\hline QUESTION & RESPONSE CODE & SKIP \\
\hline 34. For what reasons would you not & 1. Religion & \\
use condoms? (Circle all that & 2. Limited pleasure & \\
apply) & 3. Condoms encourage & \\
& 4. Utilize another method of & \\
& 5. Price panning \\
& 6. Access to condoms not easy & \\
& 7. Against family planning & \\
& 8. Don't have a sex partner & \\
\hline
\end{tabular}

END OF INTERVIEW

Interviewer: Verify that you have not forgotten any question. Thank the respondent for his attention. 


\section{APPENDIX II}

\section{MODEL INTERVIEWERS’ MANUAL}

Instructions For Completing Price Increment and Related Questions for Model Questionnaire: Current and Potential Users of Clinical Services (Facility Exit Interview)

\section{MODEL CODING MANUAL}

Instructions for Coding Model Questionnaire: Current and Potential Users of Clinical Services (Facility Exit Interview) 


\section{Willingness to Pay}

\section{Model Interviewers' Manual}

Instructions for Completing Price Increment and Related Questions for Model Questionnaire: Current and Potential Users of Clinical Services (Facility Exit Interview)

\section{GENERAL INSTRUCTIONS}

A. Always use a pencil (soft or medium lead).

B. Print all letters and numbers clearly.

C. Fill out all questions that are applicable to the person being interviewed.

D. Do not leave a blank. If the answer to a question is a non-response, circle 99 for No Response. If a number is zero, write 00 .

E. Comments should be written down when they are made. Inform your supervisor of all comments or questions as soon as possible.

F. The supervisor should make a note of all comments and questions and report them to the study coordinator.

G. All instructions for interviewers should be in capital letters and boldface type. These instructions should not be read to the interviewee. For example:

\begin{tabular}{|l|l|l|l|}
\hline Q. & QUESTION & RESPONSE CODE & SKIP \\
\hline 207 & What is your family's TOTAL income per month? & Total ALL SOURCES & \\
& $\begin{array}{l}\text { PROBE FOR ALL SOURCES OF INCOME } \\
\text { (i.e., RENT, GIFTS, ETC.) }\end{array}$ & & \\
& $\begin{array}{l}\text { AMOUNT MUST BE GREATER THAN OR } \\
\text { EQUAL TO (Q.203 + Q.205) }\end{array}$ & & \\
\hline
\end{tabular}

\section{QUESTIONNAIRE STRUCTURE}

\section{A. Organization}

The questionnaire is organized into rows and columns. For example:

\begin{tabular}{|l|l|l|l|}
\hline Q. & QUESTION & RESPONSE CODE & SKIP \\
\hline 300 & Is this your first visit to AGENCY? & Yes & GO TO 302 \\
\hline 301 & $\begin{array}{l}\text { No your visit today a "revisit" scheduled during a } \\
\text { previous appointment? }\end{array}$ & Yes & 2 \\
\hline
\end{tabular}


The first column contains the question number. The second column gives the question that must be read to the interviewee as well as any instructions for the interviewer. These instructions are given in bold.

The third column contains the responses and their codes. Be sure to circle the appropriate code (for example in question 300 the code for "Yes" is 1 and the code for "No" is 2). For open-ended questions, be sure to record the response verbatim. For example:

\begin{tabular}{|c|c|c|c|c|}
\hline Q. & QUESTION & RESPONSE CODE & & SKIP \\
\hline 201 & Do you work outside the home? & $\begin{array}{l}\text { Yes } \\
\text { No }\end{array}$ & $\begin{array}{l}1 \\
2\end{array}$ & GO TO 204 \\
\hline 202 & What type of job do you have? & Job & & \\
\hline
\end{tabular}

The fourth column contains the skip instructions, if any.

\section{B. Skips}

The instructions in the fourth column, labeled "SKIP," tell the interviewer what question to go to. Different answers in column three often skip respondents to different questions.

For example:

\begin{tabular}{|l|l|ll|l|}
\hline Q. & QUESTION & RESPONSE CODE & SKIP \\
\hline 302 & What is the main service you received today? & Gynecology & GO TO 400 \\
& & Injectable Contraceptive & 2 & GO TO 500 \\
& & IUD Insertion & 3 & GO TO 600 \\
& & IUD Revisit & 4 & GO TO 700 \\
& & Pill Visit & 5 & GO TO 800 \\
& & Prenatal Care & 6 & GO TO 900 \\
& & Other: specify & 88 & GO TO END \\
\hline
\end{tabular}

In the case of question 302, respondents who state that they came to the clinic for a gynecology service are skipped to question 400 . Those who answered that they came for an IUD insertion are skipped to question 600 .

Skips are probably the most difficult part of any questionnaire for an interviewer. Take extra care when dealing with skip instructions. If you miss a skip, the result will be lost data and respondent confusion. Supervisors should carefully review all questionnaires for skip pattern errors.

\section{Dates}

When a date is requested (for example, date of interview), always use two numbers. For example, if the date is May 6, 2000, it should be written as: day $\underline{06}$ mo $\underline{05}$ yr $\underline{00}$.

\section{Money}

Do not use decimals. For example, write 25 pesos instead of 25.00 . If the respondent quotes a figure that is not a whole number, round down. For example, a response of 10.75 pesos should be rounded to 10 pesos and a figure of less than one peso should be rounded to 00 . Sums of less than 10 should be preceded by a zero. For example, 5 pesos should be written as 05 pesos. 


\section{SELECTION OF WOMEN TO BE INTERVIEWED}

A. Only interview women who have come for one of the services listed on the questionnaire. These services include

- Gynecology

- Injectable contraceptive

- IUD insertion

- IUD revisit

- Pill visit

- Prenatal care

B. Interviews should be conducted in the clinic during clinic working hours.

C. The midwife should introduce the client to the interviewer when the client finishes seeing the midwife and has received all services and made all purchases.

D. The interviewer should fill out the questionnaire number, the code of the clinic, the interviewer's name, the date and the time the interview began prior to beginning the interview. The code of the clinic should be furnished to the interviewer on a separate card or sheet of paper.

\section{INTRODUCTION}

The first tasks facing the interviewer are to introduce herself, inform the potential respondent about the objectives, risks and benefits of the research, and obtain the consent of the respondent to be interviewed. Most research organizations require that the interviewee give informed consent. Informed consent derives from medical research where there are risks and benefits. Consent forms should use simple sentences and direct statements, appropriate to the literacy or educational level of the setting. The study participant must have an opportunity to ask questions and be fully informed before signing the consent form. Where informed consent is required, the following elements must be included:

1. Purpose of study.

2. Risks to the study participant, including physical, social, and emotional.

3. Benefits to the study participant, including, if necessary, a statement that there are none.

4. Information on confidentiality, including the use of identifiers and access to personal data.

5. Place to go with questions or problems at any time.

6. Information regarding withdrawal from the study. The study participant has the right to leave at any time without penalty.

7. Guarantee that services are available whether or not the potential respondent agrees to participate in the study, or if s/he withdraws.

8. Information on study procedures and duration.

In terms of placement, the form should be on a separate sheet of paper. Note that the researcher must be able to link the informed consent form to the relevant questionnaire with a numerical indicator. For data collection that represents low risk, oral consent is sufficient, but the form should be signed by the interviewer as part of the documentation.

Different organizations have different ways of assuring informed consent. Below is one example from a WTP survey.

\section{INSTRUCTIONS TO THE INTERVIEWER: The following statement should be read to every potential interviewee:}

May I have a minute of your time, please? AGENCY wants to continue providing you with convenient, high quality services. In order to do this, it will be necessary for AGENCY to raise the prices of some services. We want to know how you will be affected by these price changes. There are no right or wrong answers, so please be honest and tell us what is true for you. The information being collected is for planning purposes only and there are no personal risks or benefits to your participation. I do not need to know your name and address. Everything that you say will be confidential, and the only identifier on the questionnaire will be a number, not your name. No one, including the staff of this clinic, will be told what 
you personally have told us, and no one will be given your name. The services will be available to you whether or not you agree to participate in this study. The interview takes about fifteen minutes. You can terminate the interview whenever you want without consequences. Do you have any questions? Would you like to participate? If you would like to know more about this study, please contact at
1. Participation
YES (proceed to interview)
NO (thank respondent and wish her a nice day)

All questionnaires will be saved by the interviewer regardless of the respondent's decision to participate or not to participate.

\section{INSTRUCTIONS FOR COMPLETING INDIVIDUAL QUESTIONS}

The final interviewer's manual should contain complete instructions for filling out every question in the questionnaire. For example:

Question 302: This is the most important question in the questionnaire. It directs you to the different sections that need to be filled out, based on the main service the client received.

\begin{tabular}{|c|c|c|c|c|}
\hline Q. & QUESTION & RESPONSE CODE & & SKIP \\
\hline \multirow[t]{7}{*}{302} & What is the main service you received today? & Gynecology & 1 & GO TO 400 \\
\hline & & Injectable Contraceptive & 2 & GO TO 500 \\
\hline & & IUD Insertion & 3 & GO TO 600 \\
\hline & & IUD Revisit & 4 & GO TO 700 \\
\hline & & Pill Visit & 5 & GO TO 800 \\
\hline & & Prenatal Care & 6 & GO TO 900 \\
\hline & & Other: specify & 88 & GO TO END \\
\hline
\end{tabular}

Based on the answer to this question, the interviewer needs to make a correct skip to the next section. Once the interviewer is in the correct section, she must ask all questions included in that section.

If the woman has received two or more services, the interviewer must probe by asking "What is the main service you received today?" In all cases, the respondent must identify a single main service. The respondent must identify the main service received; the interviewer must not identify it for her.

\section{WILLINGNESS TO PAY QUESTIONS}

The focus of this survey is to determine the client's willingness to pay for the services included in this questionnaire. The first task facing the interviewer is to determine how much the respondent has just paid for the service that she received. Once at the appropriate section, the questionnaire instructs the interviewer to tell the client what the current cost of the service is and stress that this is only the cost of the main service she received and that the total price she paid may have been higher. Next, the client is asked if she has paid the current price.

\begin{tabular}{|l|l|l|c|}
\hline Q. & QUESTION & RESPONSE CODE & SKIP \\
\hline 400 & $\begin{array}{l}\text { READ TO CLIENT: } \\
\text { The current cost of a gynecology consultation is I/10 Intis. This is just the cost of the consultation, }\end{array}$ & \\
& $\begin{array}{l}\text { your total cost may have been greater if other tests recommended by clinic personnel were } \\
\text { performed. }\end{array}$ & $\begin{array}{l}\text { Yes } \\
\text { No }\end{array}$ & GO TO 404 \\
\hline 401 & Did you pay the consultation price posted above? & \multicolumn{2}{|l}{} \\
\hline
\end{tabular}

If the client answers No in question 401, the interviewer is instructed to ask the reason. At this point the interviewer must determine if the difference is due to the cost of other purchased services, a previous balance, or if the client received a discount because she was unable to pay the posted price. This may mean asking the physician or clinic 
cashier. If it is determined that the client is too poor to pay the current price, the interviewer will thank the client and end the interview. If the reason for giving a price different from the standard price was confusion because of multiple purchases or payment of a previous balance, the interviewer should enter the standard price, and continue the interview.

\begin{tabular}{|l|l|l|l|}
\hline Q. & QUESTION & RESPONSE CODE & SKIP \\
\hline 402 & How much did you pay? & Amount: & \\
\hline 403 & Why did you pay more/less than the posted price? & Reason: & \\
& $\begin{array}{l}\text { DETERMINE IF DIFFERENCE IN PRICE IS } \\
\text { DUE TO PAYING FOR OTHER SERVICES. } \\
\text { IF YES, CONTINUE INTERVIEW. IF NO, } \\
\text { RECORD REASON AND END INTERVIEW. }\end{array}$ & & \\
\hline
\end{tabular}

The second task is to read the following statement to the client:

\section{\begin{tabular}{l|l}
\hline 404 & READ TO CLIENT:
\end{tabular}}

I would now like to ask you some questions about your response to potential changes in the price of this consultation fee. In answering these questions, please bear in mind the following:

1. Assume that your income will stay the same even if AGENCY prices change.

2. Alternatives do exist for AGENCY services. (i.e., Ministry of Health, private clinic, etc.)

It is essential that the client understands the above assumptions.

The willingness to pay (WTP) question sequence. Once the interviewer has verified the client has paid the current price and has read her the above assumptions, the interviewer goes on to ask the willingness to pay questions. The willingness to pay sequence consists of questions about two pre-determined price increases and a third, open-ended, question to determine the maximum amount the woman would be willing to pay for the service.

The first step in asking willingness to pay questions is to tell the woman to assume that the price of the service will increase by a given amount, for example by I/5 Intis.

\begin{tabular}{|l|l|ll|l|}
\hline Q. & QUESTION & RESPONSE CODE & SKIP \\
\hline 405 & $\begin{array}{l}\text { Suppose that the price of a gynecology } \\
\text { consultation increased by I/5 to I/15. Would you } \\
\text { use AGENCY for your gynecology visits if the } \\
\text { price were I/15? }\end{array}$ & $\begin{array}{l}\text { Yes } \\
\text { Don't Know }\end{array}$ & 2 & GO TO 407 \\
GO TO 407 \\
\hline
\end{tabular}

If the client is willing to pay an increase of $\mathrm{I} / 5$, we continue to the next question (406) to determine if she is willing to pay an even higher price increase.

\begin{tabular}{|c|c|c|c|c|}
\hline Q. & QUESTION & RESPONSE CODE & & SKIP \\
\hline 406 & $\begin{array}{l}\text { Suppose that the price of a gynecology } \\
\text { consultation increased even further-by } \mathrm{I} / 10 \text { to } \\
\mathrm{I} / 20 \text {. Would you use AGENCY for your } \\
\text { gynecology visits if the price were } \mathrm{I} / 20 \text { ? }\end{array}$ & $\begin{array}{l}\text { Yes } \\
\text { No } \\
\text { Don't Know }\end{array}$ & $\begin{array}{l}1 \\
2 \\
99\end{array}$ & $\begin{array}{l}\text { GO TO } 408 \\
\text { GO TO } 408 \\
\text { GO TO } 408\end{array}$ \\
\hline
\end{tabular}

If the client is not willing to pay an increase of $\mathrm{I} / 5$ Intis in question 405 , we skip to question 407 to determine if she is willing to pay a lower price increase.

\begin{tabular}{|c|c|c|c|c|}
\hline Q. & QUESTION & RESPONSE CODE & & SKIP \\
\hline 407 & $\begin{array}{l}\text { Suppose that the price increase was less than the } \\
\text { previous amount. Suppose the price of a } \\
\text { gynecology consultation increased by I/2 to I/ } 12 \text {. } \\
\text { Would you use AGENCY for your gynecology } \\
\text { visits if the price were } I / 12 \text { ? }\end{array}$ & $\begin{array}{l}\text { Yes } \\
\text { No } \\
\text { Don't Know }\end{array}$ & $\begin{array}{l}1 \\
2 \\
99\end{array}$ & \\
\hline
\end{tabular}


Please note that there is a total of three closed willingness to pay questions, but no respondent is asked more than two closed willingness to pay questions.

All clients, regardless of their answers to the above questions, are asked the following open-ended question about the maximum price they would be willing to pay.

\begin{tabular}{|l|l|l|l|}
\hline Q. & QUESTION & RESPONSE CODE & SKIP \\
\hline 408 & $\begin{array}{l}\text { What would be the highest price you would be } \\
\text { willing to pay for gynecology services from } \\
\text { AGENCY? }\end{array}$ & Amount & \\
\hline
\end{tabular}

Finally, we ask what the woman would do if the price of the service increased to the point where the respondent would be unwilling or unable to pay (409 and 410). In the case of contraceptive methods, "Switch to a cheaper method" is added as a possible response.

\begin{tabular}{|c|c|c|c|c|}
\hline Q. & QUESTION & RESPONSE CODE & & SKIP \\
\hline 409 & $\begin{array}{l}\text { If AGENCY increased the price of the } \\
\text { gynecology service beyond what you were } \\
\text { willing or able to pay, what would you do? }\end{array}$ & $\begin{array}{l}\text { Go without service } \\
\text { Go somewhere else } \\
\text { I don't know } \\
\text { Other: specify }\end{array}$ & $\begin{array}{l}1 \\
2 \\
99 \\
88 \\
\end{array}$ & $\begin{array}{l}\text { GO TO } 1000 \\
\text { GO TO } 410 \\
\text { GO TO } 1000 \\
\text { GO TO } 1000 \\
\end{array}$ \\
\hline 410 & $\begin{array}{l}\text { Where would you go? } \\
\text { DO NOT READ CHOICES } \\
\text { CODE ALL MENTIONED }\end{array}$ & $\begin{array}{l}\text { Public Sector } \\
\text { Other NGO } \\
\text { Private Sector } \\
\text { Pharmacy } \\
\text { Other: specify } \\
\text { I don't know }\end{array}$ & $\begin{array}{l}1 \\
2 \\
3 \\
4 \\
88 \\
99 \\
\end{array}$ & $\begin{array}{l}\text { GO TO } 1000 \\
\text { GO TO } 1000 \\
\text { GO TO } 1000 \\
\text { GO TO } 1000 \\
\text { GO TO } 1000 \\
\text { GO TO } 1000\end{array}$ \\
\hline
\end{tabular}

At the end of this section, the interviewer will find a skip instruction that will move the interview to the 1000 section and the remainder of the questionnaire (WTP for potential users and WTP for amenities and quality improvements). These questions are asked of all interviewees that have completed the above willingness to pay sequence. 
Reproductive Health

Willingness to Pay

Model Coding Manual

Model Questionnaire for Current and Potential Users

of Clinical Services (Facility Interviews)

Population Council

June 2001

DATA DICTIONARY AND CODING GUIDE

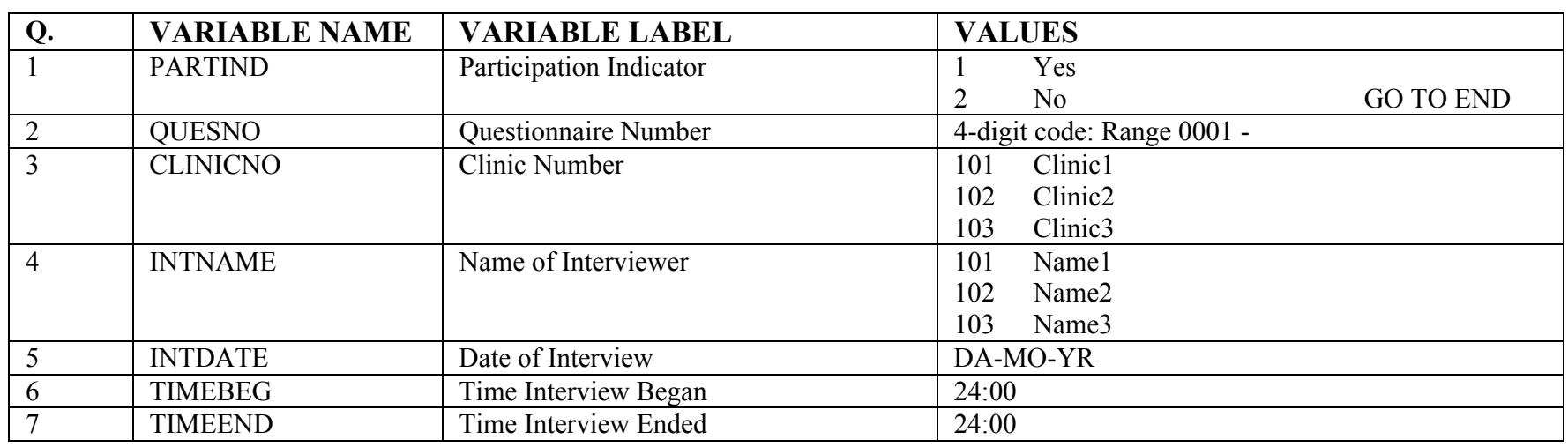

\section{A. Demographic Questions}

\begin{tabular}{|c|c|c|c|}
\hline 100 & $\mathrm{AGE}$ & Age at last birthday & 2 digit code \\
\hline 101 & MARITAL & Marital status & $\begin{array}{ll}1 & \text { Married/In-Union } \\
2 & \text { Widowed, Separated, Divorced } \\
3 & \text { Single }\end{array}$ \\
\hline 102 & CHILDREN & Number of living children TOTAL & 2 digit code $\quad$ IF 00, GO TO 104 \\
\hline 103 & CHILD1 & Number of living children age $<1$ & 1 digit code \\
\hline 103 & CHILD2 & Number of living children age 1-3 & 1 digit code \\
\hline 103 & CHILD3 & Number of living children age 4 or older & 2 digit code \\
\hline 104 & EDULEVEL & Highest grade/year completed & $\begin{array}{ll}00 & \text { No grade completed } \\
1 & \text { Elementary grade } 1 \\
2 & \text { Elementary grade } 2 \\
3 & \text { Elementary grade } 3 \\
4 & \text { Elementary grade } 4 \\
5 & \text { Elementary grade } 5 \\
6 & \text { Elementary grade } 6 \\
7 & \text { High school grade } 7 \\
8 & \text { High school grade } 8 \\
9 & \text { High school grade } 9 \\
10 & \text { High school grade } 10 \\
11 & \text { Some college/Vocational } 11 \\
12 & \text { Some college/Vocational } 12 \\
13 & \text { Some college/Vocational } 13 \\
14 & \text { Some college } 14 \\
15 & \text { Some college } 15 \\
16+ & \text { Some college } 16 \\
99 & \text { No response }\end{array}$ \\
\hline
\end{tabular}


B. Ability to Pay Questions

\begin{tabular}{|c|c|c|c|c|c|}
\hline 200 & HHELEC & Does household have electricity? & $\begin{array}{l}1 \\
2 \\
99\end{array}$ & $\begin{array}{l}\text { Yes } \\
\text { No } \\
\text { No response }\end{array}$ & \\
\hline 200 & HHWATER & Does household have piped water? & $\begin{array}{l}1 \\
2 \\
99\end{array}$ & $\begin{array}{l}\text { Yes } \\
\text { No } \\
\text { No response }\end{array}$ & \\
\hline 200 & HHFLTOIL & Does household have flush toilet? & $\begin{array}{l}1 \\
2 \\
99\end{array}$ & $\begin{array}{l}\text { Yes } \\
\text { No } \\
\text { No response }\end{array}$ & \\
\hline 200 & HHRADIO & Does household have a radio? & $\begin{array}{l}1 \\
2 \\
99\end{array}$ & $\begin{array}{l}\text { Yes } \\
\text { No } \\
\text { No response }\end{array}$ & \\
\hline 200 & HHTV & Does household have a television? & $\begin{array}{l}1 \\
2 \\
99 \\
\end{array}$ & $\begin{array}{l}\text { Yes } \\
\text { No } \\
\text { No response }\end{array}$ & \\
\hline 200 & HHVCR & Does household have a VCR? & $\begin{array}{l}1 \\
2 \\
99\end{array}$ & $\begin{array}{l}\text { Yes } \\
\text { No } \\
\text { No response }\end{array}$ & \\
\hline 200 & HHTELE & Does household have a telephone? & $\begin{array}{l}1 \\
2 \\
99\end{array}$ & $\begin{array}{l}\text { Yes } \\
\text { No } \\
\text { No response }\end{array}$ & \\
\hline 200 & HHVEHCL & $\begin{array}{l}\text { Does household have a car or pick-up } \\
\text { truck? }\end{array}$ & $\begin{array}{l}1 \\
2 \\
99 \\
\end{array}$ & $\begin{array}{l}\text { Yes } \\
\text { No } \\
\text { No response }\end{array}$ & \\
\hline 201 & WORKOUT & Do you work outside of the home? & $\begin{array}{l}1 \\
2 \\
99 \\
\end{array}$ & $\begin{array}{l}\text { Yes } \\
\text { No } \\
\text { No response }\end{array}$ & \\
\hline 202 & JOBTYPE & What type of job do you have? & \multicolumn{3}{|c|}{ Recode verbatim response } \\
\hline 203 & MOINC1 & Interviewee monthly income & \multicolumn{3}{|c|}{4 digit code } \\
\hline 204 & WORKPART & Does partner work? & $\begin{array}{l}1 \\
2 \\
3 \\
99\end{array}$ & $\begin{array}{l}\text { Yes } \\
\text { No } \\
\text { Do not have partner } \\
\text { No response }\end{array}$ & $\begin{array}{l}\text { GO TO } 206 \\
\text { GO TO } 206 \\
\text { GO TO } 206\end{array}$ \\
\hline 204 & JOBTYPEP & Type of job of partner & \multicolumn{3}{|c|}{ Recode verbatim response } \\
\hline 205 & MOINC2 & Partner monthly income & \multicolumn{3}{|c|}{4 digit code } \\
\hline 206 & SUPPORT & $\begin{array}{l}\text { Who provides the family with monetary } \\
\text { support? }\end{array}$ & $\begin{array}{l}1 \\
2 \\
3 \\
4\end{array}$ & $\begin{array}{l}\text { Interviewee } \\
\text { Spouse/partner } \\
\text { Children } \\
\text { Other }\end{array}$ & \\
\hline 207 & INCTOTAL & Total family income - ALL SOURCES & \multicolumn{3}{|c|}{4 digit code } \\
\hline
\end{tabular}

\section{Type of Visit}

\begin{tabular}{|c|c|c|c|c|c|}
\hline 300 & VISIT1 & First visit to AGENCY? & $\begin{array}{l}1 \\
2 \\
\end{array}$ & $\begin{array}{l}\text { Yes } \\
\text { No }\end{array}$ & GO TO 302 \\
\hline 301 & REVISIT & Revisit scheduled at previous visit? & $\begin{array}{l}1 \\
2\end{array}$ & $\begin{array}{l}\text { Yes } \\
\text { No }\end{array}$ & \\
\hline 302 & SERVICE & Main service received & $\begin{array}{l}1 \\
2 \\
3 \\
4 \\
5 \\
6 \\
88\end{array}$ & $\begin{array}{l}\text { Gynecology } \\
\text { Injectable contraceptive } \\
\text { IUD insertion } \\
\text { IUD revisit } \\
\text { Pill visit } \\
\text { Prenatal } \\
\text { Other }\end{array}$ & $\begin{array}{l}\text { GO TO } 401 \\
\text { GO TO } 501 \\
\text { GO TO } 601 \\
\text { GO TO } 701 \\
\text { GO TO } 801 \\
\text { GO TO } 901 \\
\text { GO TO END }\end{array}$ \\
\hline
\end{tabular}




\section{Willingness to Pay Questions: Current Users}

1. Gynecology

\begin{tabular}{|c|c|c|c|c|c|}
\hline 401 & GYNPAY & Did you pay posted consultation price? & $\begin{array}{l}1 \\
2 \\
99\end{array}$ & $\begin{array}{l}\text { Yes } \\
\text { No } \\
\text { No response }\end{array}$ & GO TO 405 \\
\hline 402 & GYNPAID & Amount paid & \multicolumn{3}{|c|}{2 digit code } \\
\hline 403 & GYNREAS & Reason for not paying posted price & \multicolumn{3}{|c|}{ Recode verbatim response } \\
\hline 405 & GYNWTPM & $\begin{array}{l}\text { Willing to pay I/5 more for gynecology } \\
\text { services }\end{array}$ & $\begin{array}{l}1 \\
2 \\
99\end{array}$ & $\begin{array}{l}\text { Yes } \\
\text { No } \\
\text { Don't know }\end{array}$ & $\begin{array}{l}\text { GO TO } 407 \\
\text { GO TO } 407\end{array}$ \\
\hline 406 & GYNWTPH & $\begin{array}{l}\text { Willing to pay } \mathrm{I} / 10 \text { more for gynecology } \\
\text { services }\end{array}$ & $\begin{array}{l}1 \\
2 \\
99\end{array}$ & $\begin{array}{l}\text { Yes } \\
\text { No } \\
\text { Don't know }\end{array}$ & $\begin{array}{l}\text { GO TO } 408 \\
\text { GO TO } 408 \\
\text { GO TO } 408\end{array}$ \\
\hline 407 & GYNWTPL & $\begin{array}{l}\text { Willing to pay I/2 more for gynecology } \\
\text { services }\end{array}$ & $\begin{array}{l}1 \\
2 \\
99\end{array}$ & $\begin{array}{l}\text { Yes } \\
\text { No } \\
\text { Don't know }\end{array}$ & \\
\hline 408 & GYNWTPS & $\begin{array}{l}\text { Maximum amount willing to pay for } \\
\text { gynecology services. }\end{array}$ & \multicolumn{3}{|c|}{3 digit code } \\
\hline 409 & GYNALT & $\begin{array}{l}\text { What would you do if price were too } \\
\text { high? }\end{array}$ & $\begin{array}{l}1 \\
2 \\
88 \\
99\end{array}$ & $\begin{array}{l}\text { Go without service } \\
\text { Go somewhere else } \\
\text { Other } \\
\text { I don't know }\end{array}$ & $\begin{array}{l}\text { GO TO } 1000 \\
\text { GO TO } 410 \\
\text { GO TO } 1000 \\
\text { GO TO } 1000\end{array}$ \\
\hline 410 & GYNALTP & $\begin{array}{l}\text { Gynecology service provider alternative } \\
\text { if price is too high }\end{array}$ & $\begin{array}{l}1 \\
2 \\
3 \\
4 \\
88 \\
99\end{array}$ & $\begin{array}{l}\text { Public sector } \\
\text { Other NGO } \\
\text { Private sector } \\
\text { Pharmacy } \\
\text { Other } \\
\text { I don't know }\end{array}$ & $\begin{array}{l}\text { GO TO } 1000 \\
\text { GO TO } 1000 \\
\text { GO TO } 1000 \\
\text { GO TO } 1000 \\
\text { GO TO } 1000 \\
\text { GO TO } 1000\end{array}$ \\
\hline
\end{tabular}

2. Injectable Contraceptive

\begin{tabular}{|c|c|c|c|c|c|}
\hline 501 & INCPAY & Did you pay posted consultation price? & $\begin{array}{l}1 \\
2 \\
99 \\
\end{array}$ & $\begin{array}{l}\text { Yes } \\
\text { No } \\
\text { No response }\end{array}$ & GO TO 505 \\
\hline 502 & INCPAID & Amount paid & \multicolumn{3}{|c|}{3 digit code } \\
\hline 503 & INCREAS & Reason for not paying posted price & \multicolumn{3}{|c|}{ Recode verbatim response } \\
\hline 505 & INCWTPM & $\begin{array}{l}\text { Willing to pay I/5 more for injectable } \\
\text { contraceptive }\end{array}$ & $\begin{array}{l}1 \\
2 \\
99\end{array}$ & $\begin{array}{l}\text { Yes } \\
\text { No } \\
\text { Don't know }\end{array}$ & $\begin{array}{l}\text { GO TO } 507 \\
\text { GO TO } 507\end{array}$ \\
\hline 506 & INCWTPH & $\begin{array}{l}\text { Willing to pay } \mathrm{I} / 10 \text { more for injectable } \\
\text { contraceptive }\end{array}$ & $\begin{array}{l}1 \\
2 \\
99\end{array}$ & $\begin{array}{l}\text { Yes } \\
\text { No } \\
\text { Don't know }\end{array}$ & $\begin{array}{l}\text { GO TO } 508 \\
\text { GO TO } 508 \\
\text { GO TO } 508\end{array}$ \\
\hline 507 & INCWTPL & $\begin{array}{l}\text { Willing to pay I/3 more for injectable } \\
\text { contraceptive }\end{array}$ & $\begin{array}{l}1 \\
2 \\
99 \\
\end{array}$ & $\begin{array}{l}\text { Yes } \\
\text { No } \\
\text { Don't know }\end{array}$ & \\
\hline 508 & INCWTPS & $\begin{array}{l}\text { Maximum amount willing to pay for } \\
\text { injectable contraceptive. }\end{array}$ & \multicolumn{3}{|c|}{3 digit code } \\
\hline 509 & INCALT & $\begin{array}{l}\text { What would you do if price were too } \\
\text { high? }\end{array}$ & $\begin{array}{l}1 \\
2 \\
3 \\
88 \\
99 \\
\end{array}$ & $\begin{array}{l}\text { Not use contraception } \\
\text { Go somewhere else } \\
\text { Switch to a cheaper method } \\
\text { Other } \\
\text { I don't know }\end{array}$ & $\begin{array}{l}\text { GO TO } 1000 \\
\text { GO TO } 510 \\
\text { GO TO } 1000 \\
\text { GO TO } 1000 \\
\text { GO TO } 1000\end{array}$ \\
\hline 510 & INCALTP & $\begin{array}{l}\text { Injectable contraceptive provider } \\
\text { alternative if price is too high }\end{array}$ & $\begin{array}{l}1 \\
2 \\
3 \\
4 \\
88 \\
99 \\
\end{array}$ & $\begin{array}{l}\text { Public sector } \\
\text { Other NGO } \\
\text { Private sector } \\
\text { Pharmacy } \\
\text { Other } \\
\text { I don't know }\end{array}$ & $\begin{array}{l}\text { GO TO } 1000 \\
\text { GO TO } 1000 \\
\text { GO TO } 1000 \\
\text { GO TO } 1000 \\
\text { GO TO } 1000 \\
\text { GO TO } 1000\end{array}$ \\
\hline
\end{tabular}




\begin{tabular}{|c|c|c|c|c|c|}
\hline 601 & IUDPAY & Did you pay posted consultation price? & $\begin{array}{l}1 \\
2 \\
99\end{array}$ & $\begin{array}{l}\text { Yes } \\
\text { No } \\
\text { No response }\end{array}$ & GO TO 605 \\
\hline 602 & IUDPAID & Amount paid & \multicolumn{3}{|c|}{2 digit code } \\
\hline 603 & IUDREAS & Reason for not paying posted price & \multicolumn{3}{|c|}{ Recode verbatim response } \\
\hline 605 & IUDWTPM & Willing to pay $\mathrm{I} / 5$ more for IUD insertion & $\begin{array}{l}1 \\
2 \\
99\end{array}$ & $\begin{array}{l}\text { Yes } \\
\text { No } \\
\text { Don't know }\end{array}$ & $\begin{array}{l}\text { GO TO } 607 \\
\text { GO TO } 607\end{array}$ \\
\hline 606 & IUDWTPH & $\begin{array}{l}\text { Willing to pay } \mathrm{I} / 10 \text { more for IUD } \\
\text { insertion }\end{array}$ & $\begin{array}{l}1 \\
2 \\
99\end{array}$ & $\begin{array}{l}\text { Yes } \\
\text { No } \\
\text { Don't know }\end{array}$ & $\begin{array}{l}\text { GO TO } 608 \\
\text { GO TO } 608 \\
\text { GO TO } 608\end{array}$ \\
\hline 607 & IUDWTPL & Willing to pay I/3 more for IUD insertion & $\begin{array}{l}1 \\
2 \\
99 \\
\end{array}$ & $\begin{array}{l}\text { Yes } \\
\text { No } \\
\text { Don't know }\end{array}$ & \\
\hline 608 & IUDWTPS & $\begin{array}{l}\text { Maximum amount willing to pay for IUD } \\
\text { insertion. }\end{array}$ & \multicolumn{3}{|c|}{3 digit code } \\
\hline 609 & IUDALT & $\begin{array}{l}\text { What would you do if price were too } \\
\text { high? }\end{array}$ & $\begin{array}{l}1 \\
2 \\
3 \\
88 \\
99 \\
\end{array}$ & $\begin{array}{l}\text { Not use contraception } \\
\text { Go somewhere else } \\
\text { Switch to a cheaper method } \\
\text { Other } \\
\text { I don't know }\end{array}$ & $\begin{array}{l}\text { GO TO } 1000 \\
\text { GO TO } 610 \\
\text { GO TO } 1000 \\
\text { GO TO } 1000 \\
\text { GO TO } 1000\end{array}$ \\
\hline 610 & INCALTP & $\begin{array}{l}\text { IUD insertion provider alternative if price } \\
\text { is too high }\end{array}$ & $\begin{array}{l}1 \\
2 \\
3 \\
4 \\
88 \\
99\end{array}$ & $\begin{array}{l}\text { Public sector } \\
\text { Other NGO } \\
\text { Private sector } \\
\text { Pharmacy } \\
\text { Other } \\
\text { I don't know }\end{array}$ & $\begin{array}{l}\text { GO TO } 1000 \\
\text { GO TO } 1000 \\
\text { GO TO } 1000 \\
\text { GO TO } 1000 \\
\text { GO TO } 1000 \\
\text { GO TO } 1000\end{array}$ \\
\hline
\end{tabular}

\section{IUD Revisit}

\begin{tabular}{|c|c|c|c|c|c|}
\hline 701 & IREPAY & Did you pay posted consultation price? & $\begin{array}{l}1 \\
2 \\
99\end{array}$ & $\begin{array}{l}\text { Yes } \\
\text { No } \\
\text { Don't know }\end{array}$ & GO TO 705 \\
\hline 702 & IREPAID & Amount paid & \multicolumn{3}{|c|}{2 digit code } \\
\hline 703 & IREREAS & Reason for not paying posted price & \multicolumn{3}{|c|}{ Recode verbatim response } \\
\hline 705 & IREWTPM & Willing to pay I/5 more for IUD revisit & $\begin{array}{l}1 \\
2 \\
99\end{array}$ & $\begin{array}{l}\text { Yes } \\
\text { No } \\
\text { Don't know }\end{array}$ & $\begin{array}{l}\text { GO TO } 707 \\
\text { GO TO } 707\end{array}$ \\
\hline 706 & IREWTPH & Willing to pay $\mathrm{I} / 10$ more for IUD revisit & $\begin{array}{l}1 \\
2 \\
99 \\
\end{array}$ & $\begin{array}{l}\text { Yes } \\
\text { No } \\
\text { Don't know }\end{array}$ & $\begin{array}{l}\text { GO TO } 708 \\
\text { GO TO } 708 \\
\text { GO TO } 708 \\
\end{array}$ \\
\hline 707 & IREWTPL & Willing to pay I/2 more for IUD revisit & & $\begin{array}{l}\text { Yes } \\
\text { No } \\
\text { Don't know }\end{array}$ & \\
\hline 708 & IREWTPS & $\begin{array}{l}\text { Maximum amount willing to pay for IUD } \\
\text { revisit. }\end{array}$ & \multicolumn{3}{|c|}{3 digit code } \\
\hline 709 & IREALT & $\begin{array}{l}\text { What would you do if price were too } \\
\text { high? }\end{array}$ & $\begin{array}{l}1 \\
2 \\
88 \\
99\end{array}$ & $\begin{array}{l}\text { Go without service } \\
\text { Go somewhere else } \\
\text { Other } \\
\text { I don't know }\end{array}$ & $\begin{array}{l}\text { GO TO } 1000 \\
\text { GO TO } 710 \\
\text { GO TO } 1000 \\
\text { GO TO } 1000\end{array}$ \\
\hline 710 & IREALTP & $\begin{array}{l}\text { IUD revisit provider alternative if price is } \\
\text { too high }\end{array}$ & \begin{tabular}{l|}
1 \\
2 \\
3 \\
4 \\
88 \\
99
\end{tabular} & $\begin{array}{l}\text { Public sector } \\
\text { Other NGO } \\
\text { Private sector } \\
\text { Pharmacy } \\
\text { Other } \\
\text { I don't know }\end{array}$ & $\begin{array}{l}\text { GO TO } 1000 \\
\text { GO TO } 1000 \\
\text { GO TO } 1000 \\
\text { GO TO } 1000 \\
\text { GO TO } 1000 \\
\text { GO TO } 1000\end{array}$ \\
\hline
\end{tabular}


5. Pill Purchase

\begin{tabular}{|c|c|c|c|c|c|}
\hline 801 & OCPAY & Did you pay posted consultation price? & $\begin{array}{l}1 \\
2 \\
99\end{array}$ & $\begin{array}{l}\text { Yes } \\
\text { No } \\
\text { Don't know }\end{array}$ & GO TO 804 \\
\hline 802 & OCPAID & Amount paid & \multicolumn{3}{|c|}{2 digit code } \\
\hline 803 & OCREAS & Reason for not paying posted price & \multicolumn{3}{|c|}{ Recode verbatim response } \\
\hline 805 & OCWTPM & $\begin{array}{l}\text { Willing to pay } \mathrm{I} / 2 \text { more for oral } \\
\text { contraceptives }\end{array}$ & $\begin{array}{l}1 \\
2 \\
99 \\
\end{array}$ & $\begin{array}{l}\text { Yes } \\
\text { No } \\
\text { Don't know }\end{array}$ & $\begin{array}{l}\text { GO TO } 807 \\
\text { GO TO } 807\end{array}$ \\
\hline 806 & OCWTPH & $\begin{array}{l}\text { Willing to pay } \mathrm{I} / 3 \text { more for oral } \\
\text { contraceptives }\end{array}$ & $\begin{array}{l}1 \\
2 \\
99 \\
\end{array}$ & $\begin{array}{l}\text { Yes } \\
\text { No } \\
\text { Don't know }\end{array}$ & $\begin{array}{l}\text { GO TO } 808 \\
\text { GO TO } 808 \\
\text { GO TO } 808\end{array}$ \\
\hline 807 & OCWTPL & $\begin{array}{l}\text { Willing to pay } \mathrm{I} / 1 \text { more for oral } \\
\text { contraceptives }\end{array}$ & & $\begin{array}{l}\text { Yes } \\
\text { No } \\
\text { Don't know }\end{array}$ & \\
\hline 808 & OCWTPS & $\begin{array}{l}\text { Maximum amount willing to pay for oral } \\
\text { contraceptives. }\end{array}$ & \multicolumn{3}{|c|}{3 digit code } \\
\hline 809 & OCALT & $\begin{array}{l}\text { What would you do if price were too } \\
\text { high? }\end{array}$ & $\begin{array}{l}1 \\
2 \\
3 \\
88 \\
99 \\
\end{array}$ & $\begin{array}{l}\text { Not use contraception } \\
\text { Go somewhere else } \\
\text { Switch to a cheaper method } \\
\text { Other } \\
\text { I don't know } \\
\end{array}$ & $\begin{array}{l}\text { GO TO } 1000 \\
\text { GO TO } 810 \\
\text { GO TO } 1000 \\
\text { GO TO } 1000 \\
\text { GO TO } 1000 \\
\end{array}$ \\
\hline 810 & OCALTP & $\begin{array}{l}\text { Oral contraceptive provider alternative if } \\
\text { price is too high }\end{array}$ & $\begin{array}{l}1 \\
2 \\
3 \\
4 \\
88 \\
99\end{array}$ & $\begin{array}{l}\text { Public sector } \\
\text { Other NGO } \\
\text { Private sector } \\
\text { Pharmacy } \\
\text { Other } \\
\text { I don't know }\end{array}$ & $\begin{array}{l}\text { GO TO } 1000 \\
\text { GO TO } 1000 \\
\text { GO TO } 1000 \\
\text { GO TO } 1000 \\
\text { GO TO } 1000 \\
\text { GO TO } 1000\end{array}$ \\
\hline
\end{tabular}

6.Prenatal Care

\begin{tabular}{|c|c|c|c|c|c|}
\hline 901 & PNCPAY & Did you pay posted consultation price? & $\begin{array}{l}1 \\
2 \\
99 \\
\end{array}$ & $\begin{array}{l}\text { Yes } \\
\text { No } \\
\text { Don't know }\end{array}$ & GO TO 905 \\
\hline 902 & PNCPAID & Amount paid & \multicolumn{3}{|c|}{3 digit code } \\
\hline 903 & PNCREAS & Reason for not paying posted price & \multicolumn{3}{|c|}{ Recode verbatim response } \\
\hline 905 & PNCWTPM & Willing to pay $\mathrm{I} / 5$ more for prenatal care & $\begin{array}{l}1 \\
2 \\
99\end{array}$ & $\begin{array}{l}\text { Yes } \\
\text { No } \\
\text { Don't know }\end{array}$ & $\begin{array}{l}\text { GO TO } 907 \\
\text { GO TO } 907\end{array}$ \\
\hline 906 & PNCWTPH & Willing to pay $\mathrm{I} / 10$ more for prenatal care & $\begin{array}{l}1 \\
2 \\
99\end{array}$ & $\begin{array}{l}\text { Yes } \\
\text { No } \\
\text { Don't know }\end{array}$ & $\begin{array}{l}\text { GO TO } 908 \\
\text { GO TO } 908 \\
\text { GO TO } 908\end{array}$ \\
\hline 907 & PNCWTPL & Willing to pay $\mathrm{I} / 2$ more for prenatal care & $\begin{array}{l}1 \\
2 \\
99\end{array}$ & $\begin{array}{l}\text { Yes } \\
\text { No } \\
\text { Don't know }\end{array}$ & \\
\hline 908 & PNCWTPS & $\begin{array}{l}\text { Maximum amount willing to pay for } \\
\text { prenatal care. }\end{array}$ & \multicolumn{3}{|c|}{3 digit code } \\
\hline 909 & PNCALT & $\begin{array}{l}\text { What would you do if price were too } \\
\text { high? }\end{array}$ & $\begin{array}{l}1 \\
2 \\
88 \\
99\end{array}$ & $\begin{array}{l}\text { Go without service } \\
\text { Go somewhere else } \\
\text { Other } \\
\text { I don't know }\end{array}$ & $\begin{array}{l}\text { GO TO } 1000 \\
\text { GO TO } 910 \\
\text { GO TO } 1000 \\
\text { GO TO } 1000\end{array}$ \\
\hline 910 & PNCALTP & $\begin{array}{l}\text { Prenatal care provider alternative if price } \\
\text { is too high }\end{array}$ & $\begin{array}{l}1 \\
2 \\
3 \\
4 \\
88 \\
99\end{array}$ & $\begin{array}{l}\text { Public sector } \\
\text { Other NGO } \\
\text { Private sector } \\
\text { Pharmacy } \\
\text { Other } \\
\text { I don't know }\end{array}$ & $\begin{array}{l}\text { GO TO } 1000 \\
\text { GO TO } 1000 \\
\text { GO TO } 1000 \\
\text { GO TO } 1000 \\
\text { GO TO } 1000 \\
\text { GO TO } 1000\end{array}$ \\
\hline
\end{tabular}




\section{E. WTP Questions: Potential Users}

1. Female Sterilization

\begin{tabular}{|c|c|c|c|c|c|}
\hline 1000 & VSCKNOW & $\begin{array}{l}\text { Heard of voluntary surgical } \\
\text { contraception? }\end{array}$ & $\begin{array}{l}1 \\
2 \\
99\end{array}$ & $\begin{array}{l}\text { Yes } \\
\text { No } \\
\text { Don't know }\end{array}$ & $\begin{array}{l}\text { GO TO } 1100 \\
\text { GO TO } 1100\end{array}$ \\
\hline 1001 & VSCINT & Future interest in VSC (in next 2 years) & $\begin{array}{l}1 \\
2 \\
3 \\
99\end{array}$ & $\begin{array}{l}\text { Yes } \\
\text { No } \\
\text { Already had it } \\
\text { Don't know }\end{array}$ & $\begin{array}{l}\text { GO TO } 1100 \\
\text { GO TO } 1100 \\
\text { GO TO } 1100\end{array}$ \\
\hline 1003 & VSCWTPM & Willing to pay $\mathrm{I} / 200$ for operation. & $\begin{array}{l}1 \\
2 \\
99\end{array}$ & $\begin{array}{l}\text { Yes } \\
\text { No } \\
\text { Don't know }\end{array}$ & $\begin{array}{l}\text { GO TO } 1105 \\
\text { GO TO } 1105\end{array}$ \\
\hline 1004 & VSCWTPH & Willing to pay $\mathrm{I} / 300$ for operation. & $\begin{array}{l}1 \\
2 \\
99 \\
\end{array}$ & $\begin{array}{l}\text { Yes } \\
\text { No } \\
\text { Don't know }\end{array}$ & $\begin{array}{l}\text { GO TO } 1106 \\
\text { GO TO } 1106 \\
\text { GO TO } 1106 \\
\end{array}$ \\
\hline 1005 & VSCWTPL & Willing to pay $\mathrm{I} / 100$ for operation. & $\begin{array}{l}1 \\
2 \\
99\end{array}$ & $\begin{array}{l}\text { Yes } \\
\text { No } \\
\text { Don't know }\end{array}$ & \\
\hline 1006 & VSCWTPS & Maximum willing to pay for operation. & \multicolumn{3}{|c|}{4 digit code } \\
\hline 1007 & VSCALT & VSC alternative if cost is too high & $\begin{array}{l}1 \\
2 \\
88 \\
99\end{array}$ & $\begin{array}{l}\text { Go without service } \\
\text { Go somewhere else } \\
\text { Other } \\
\text { I don't know }\end{array}$ & $\begin{array}{l}\text { GO TO } 1008 \\
\text { GO TO } 1009 \\
\text { GO TO } 1100 \\
\text { GO TO } 1100\end{array}$ \\
\hline 1008 & CONTCONT & $\begin{array}{l}\text { If no operation, continue using } \\
\text { contraception? }\end{array}$ & $\begin{array}{l}1 \\
2 \\
99\end{array}$ & $\begin{array}{l}\text { Yes } \\
\text { No } \\
\text { Don't know }\end{array}$ & $\begin{array}{l}\text { GO TO } 1100 \\
\text { GO TO } 1100 \\
\text { GO TO } 1100\end{array}$ \\
\hline 1009 & VSCALTP & $\begin{array}{l}\text { VSC provider alternative if cost is too } \\
\text { high }\end{array}$ & $\begin{array}{l}1 \\
2 \\
3 \\
88 \\
99\end{array}$ & $\begin{array}{l}\text { Public sector } \\
\text { Other NGO } \\
\text { Private sector } \\
\text { Other } \\
\text { I don't know }\end{array}$ & \\
\hline
\end{tabular}

\section{F. WTP for Amenities and Quality Improvements}

1. WTP for Reduced Waiting Time

\begin{tabular}{|c|c|c|c|c|c|}
\hline 1100 & WAITTIME & Amount of time waiting before being & \multicolumn{3}{|c|}{ Time in minutes } \\
\hline 1101 & WTPERC & $\begin{array}{l}\text { What is your opinion of this length of } \\
\text { wait? }\end{array}$ & $\begin{array}{l}1 \\
2 \\
3\end{array}$ & $\begin{array}{l}\text { Excessive } \\
\text { Reasonable } \\
\text { Short }\end{array}$ & \\
\hline 1102 & WTWTPM & $\begin{array}{l}\text { Willing to pay } \mathrm{I} / 3 \text { more for reduced } \\
\text { waiting time }\end{array}$ & $\begin{array}{l}1 \\
2 \\
99\end{array}$ & $\begin{array}{l}\text { Yes } \\
\text { No } \\
\text { Don't know }\end{array}$ & $\begin{array}{l}\text { GO TO } 1104 \\
\text { GO TO } 1104\end{array}$ \\
\hline 1103 & WTWTPH & $\begin{array}{l}\text { Willing to pay } \mathrm{I} / 6 \text { more for reduced } \\
\text { waiting time }\end{array}$ & $\begin{array}{l}1 \\
2 \\
99\end{array}$ & $\begin{array}{l}\text { Yes } \\
\text { No } \\
\text { Don't know }\end{array}$ & $\begin{array}{l}\text { GO TO } 1105 \\
\text { GO TO } 1105 \\
\text { GO TO } 1105\end{array}$ \\
\hline 1104 & WTWTPL & $\begin{array}{l}\text { Willing to pay } \mathrm{I} / 1 \text { more for reduced } \\
\text { waiting time }\end{array}$ & & $\begin{array}{l}\text { Yes } \\
\text { No } \\
\text { Don't know }\end{array}$ & \\
\hline 1105 & WTWTPS & $\begin{array}{l}\text { Maximum amount willing to pay for } \\
\text { reduced waiting time. }\end{array}$ & \multicolumn{3}{|c|}{2 digit code } \\
\hline
\end{tabular}


2. WTP for Counseling

\begin{tabular}{|c|c|c|c|c|c|}
\hline 1200 & CNSLTIME & Amount of time provider spent & \multicolumn{3}{|c|}{ Time in minutes } \\
\hline 1201 & CNSLPERC & $\begin{array}{l}\text { What is your opinion of this length of } \\
\text { counseling time? }\end{array}$ & & $\begin{array}{l}\text { Excessive } \\
\text { Reasonable } \\
\text { Short }\end{array}$ & GO TO 1300 \\
\hline 1202 & CNSWTPM & $\begin{array}{l}\text { Willing to pay } \mathrm{I} / 3 \text { more for increased } \\
\text { counseling time }\end{array}$ & $\begin{array}{l}1 \\
2 \\
99 \\
\end{array}$ & $\begin{array}{l}\text { Yes } \\
\text { No } \\
\text { Don't know }\end{array}$ & $\begin{array}{l}\text { GO TO } 1204 \\
\text { GO TO } 1204\end{array}$ \\
\hline 1203 & CNSWTPH & $\begin{array}{l}\text { Willing to pay I/6 more for increased } \\
\text { counseling time }\end{array}$ & $\begin{array}{l}1 \\
2 \\
99 \\
\end{array}$ & $\begin{array}{l}\text { Yes } \\
\text { No } \\
\text { Don't know }\end{array}$ & $\begin{array}{ll}\text { GO TO } 1205 \\
\text { GO TO } 1205 \\
\text { GO TO } 1205\end{array}$ \\
\hline 1204 & CNSWTPL & $\begin{array}{l}\text { Willing to pay I/1 more for increased } \\
\text { counseling time }\end{array}$ & $\begin{array}{l}1 \\
2 \\
99\end{array}$ & $\begin{array}{l}\text { Yes } \\
\text { No } \\
\text { Don't know }\end{array}$ & \\
\hline 1205 & CNSWTPS & $\begin{array}{l}\text { Maximum amount willing to pay for } \\
\text { increased counseling time. }\end{array}$ & \multicolumn{3}{|c|}{2 digit code } \\
\hline
\end{tabular}

3. WTP for Clinic Improvements

\begin{tabular}{|c|c|c|c|c|c|}
\hline 1301 & WRCHAIR & $\begin{array}{l}\text { Importance to interviewee of more } \\
\text { comfortable chairs in waiting room }\end{array}$ & $\begin{array}{l}1 \\
2 \\
3 \\
4 \\
5\end{array}$ & $\begin{array}{l}\text { Not very important } \\
\text { Very important }\end{array}$ & \\
\hline 1301 & WRAC & $\begin{array}{l}\text { Importance to interviewee of air- } \\
\text { conditioning in waiting room }\end{array}$ & $\begin{array}{l}1 \\
2 \\
3 \\
4 \\
5\end{array}$ & $\begin{array}{l}\text { Not very important } \\
\text { Very important }\end{array}$ & \\
\hline 1301 & WRTV & $\begin{array}{l}\text { Importance to interviewee of a television } \\
\text { in waiting room }\end{array}$ & $\begin{array}{l}1 \\
2 \\
3 \\
4 \\
5\end{array}$ & $\begin{array}{l}\text { Not very important } \\
\text { Very important }\end{array}$ & \\
\hline 1302 & MOSTIMP & $\begin{array}{l}\text { Most important improvement to } \\
\text { interviewee }\end{array}$ & $\begin{array}{l}1 \\
2 \\
3\end{array}$ & $\begin{array}{l}\text { More comfortable chairs } \\
\text { Air-conditioning } \\
\text { TV }\end{array}$ & $\begin{array}{ll}\text { GO TO } 1303 \\
\text { GO TO } 1307 \\
\text { GO TO } 1311 \\
\end{array}$ \\
\hline 1303 & CHWTPM & $\begin{array}{l}\text { Willing to pay } \mathrm{I} / 3 \text { more for more } \\
\text { comfortable chairs in waiting room }\end{array}$ & $\begin{array}{l}1 \\
2 \\
99\end{array}$ & $\begin{array}{l}\text { Yes } \\
\text { No } \\
\text { Don't know }\end{array}$ & $\begin{array}{l}\text { GO TO } 1305 \\
\text { GO TO } 1305\end{array}$ \\
\hline 1304 & CHWTPH & $\begin{array}{l}\text { Willing to pay I/ } 6 \text { more for more } \\
\text { comfortable chairs in waiting room }\end{array}$ & $\begin{array}{l}1 \\
2 \\
99\end{array}$ & $\begin{array}{l}\text { Yes } \\
\text { No } \\
\text { Don't know }\end{array}$ & $\begin{array}{l}\text { GO TO } 1306 \\
\text { GO TO } 1306 \\
\text { GO TO } 1306\end{array}$ \\
\hline 1305 & CHWTPL & $\begin{array}{l}\text { Willing to pay } \mathrm{I} / 1 \text { more for more } \\
\text { comfortable chairs in waiting room }\end{array}$ & $\begin{array}{l}1 \\
2 \\
99 \\
\end{array}$ & $\begin{array}{l}\text { Yes } \\
\text { No } \\
\text { Don't know }\end{array}$ & \\
\hline 1306 & CHWTPS & $\begin{array}{l}\text { Maximum amount willing to pay for } \\
\text { more comfortable chairs in waiting room. }\end{array}$ & \multicolumn{3}{|c|}{2 digit code } \\
\hline 1307 & ACWTPM & $\begin{array}{l}\text { Willing to pay I/3 more for air- } \\
\text { conditioning in waiting room }\end{array}$ & $\begin{array}{l}1 \\
2 \\
99\end{array}$ & $\begin{array}{l}\text { Yes } \\
\text { No } \\
\text { Don't know }\end{array}$ & $\begin{array}{l}\text { GO TO } 1309 \\
\text { GO TO } 1309\end{array}$ \\
\hline 1308 & ACWTPH & $\begin{array}{l}\text { Willing to pay I/ } 6 \text { more for air- } \\
\text { conditioning in waiting room }\end{array}$ & $\begin{array}{l}1 \\
2 \\
99 \\
\end{array}$ & $\begin{array}{l}\text { Yes } \\
\text { No } \\
\text { Don't know }\end{array}$ & $\begin{array}{l}\text { GO TO } 1310 \\
\text { GO TO } 1310 \\
\text { GO TO } 1310 \\
\end{array}$ \\
\hline 1309 & ACWTPL & $\begin{array}{l}\text { Willing to pay I/1 more for air- } \\
\text { conditioning in waiting room }\end{array}$ & $\begin{array}{l}1 \\
2 \\
99\end{array}$ & $\begin{array}{l}\text { Yes } \\
\text { No } \\
\text { Don't know }\end{array}$ & \\
\hline
\end{tabular}




\begin{tabular}{|c|c|c|c|c|c|}
\hline 1310 & ACWTPS & Maximum amount willing to pay for air- & \multicolumn{3}{|c|}{2 digit code } \\
\hline 1311 & TVWTPM & $\begin{array}{l}\text { Willing to pay } \mathrm{I} / 3 \text { more for television in } \\
\text { waiting room }\end{array}$ & $\begin{array}{l}1 \\
2 \\
99\end{array}$ & $\begin{array}{l}\text { Yes } \\
\text { No } \\
\text { Don't know }\end{array}$ & $\begin{array}{l}\text { GO TO } 1313 \\
\text { GO TO } 1313\end{array}$ \\
\hline 1312 & TVWTPH & $\begin{array}{l}\text { Willing to pay } \mathrm{I} / 6 \text { more for television in } \\
\text { waiting room }\end{array}$ & $\begin{array}{l}1 \\
2 \\
99 \\
\end{array}$ & $\begin{array}{l}\text { Yes } \\
\text { No } \\
\text { Don't know }\end{array}$ & $\begin{array}{ll}\text { GO TO } & 1314 \\
\text { GO TO } & 1314 \\
\text { GO TO } & 1314 \\
\end{array}$ \\
\hline 1313 & TVWTPL & $\begin{array}{l}\text { Willing to pay } \mathrm{I} / 1 \text { more for television in } \\
\text { waiting room }\end{array}$ & & $\begin{array}{l}\text { Yes } \\
\text { No } \\
\text { Don't know }\end{array}$ & \\
\hline 1314 & TVWTPS & $\begin{array}{l}\text { Maximum amount willing to pay for } \\
\text { television in waiting room. }\end{array}$ & \multicolumn{3}{|c|}{2 digit code } \\
\hline
\end{tabular}

